\title{
ZINC RECOVERY FROM BAGHOUSE DUST GENERATED AT FERROCHROME FOUNDRIES
}

\author{
by \\ Johannes Gerhardus Strobos
}

Submitted in partial fulfillment of the requirements for the degree

Master in Environmental Engineering (M.Eng Environmental)

In the

Faculty of Engineering, the Built Environment and Information Technology

University of Pretoria

Pretoria

2002 


\title{
Zinc recovery from baghouse dust generated at ferrochrome foundries
}

\author{
Author: Johannes Gerhardus Strobos \\ Study leader: Mr. J F C Friend \\ Department: Chemical and Environmental Engineering \\ Degree: $\quad$ MEng (Environmental Engineering)
}

\section{Synopsis}

During the production of ferrochrome in electric arc furnaces, a dust is captured in baghouse filters as a means of air pollution control. This dust contains various metals such as chromium, zinc, iron, aluminium and magnesium. Due to the presence of hexavalent chromium in the dust, which is both toxic and carcinogenic, it requires disposal at a hazardous waste disposal site, entailing high cost. The possibility exists that these costs could be reduced if metals such as zinc can be recovered from the dust through, inter alia, leaching. Experiments were performed to determine suitable conditions for the leaching of zinc from such a baghouse dust. A two step leaching procedure was followed which prevented the formation of silica gel. The most favourable conditions for zinc extraction was with a sulphuric acid concentration of $336 \mathrm{~g} / \mathrm{l}$ and an acid to dust ratio of 0,56 . Under these conditions zinc was selectively leached with regard to iron and aluminium. The percentage recovery for zinc was $71,2 \%$, aluminium $1,8 \%$ and iron $0,1 \%$. It was concluded that the second step (dilution) of leaching did not have a significant influence on the percentage extraction of metals from the dust.

Consideration of the chemical treatment cost of waste streams produced led to the conclusion that zinc recovery from baghouse dust is not an economically feasible project viewed in isolation. However, compared to disposal at a hazardous waste disposal site such as Holfontein, approximately R 467054,00 per annum (based on a seven day week and baghouse dust production of $3600 \mathrm{~kg} /$ day) can be saved.

KEY WORDS: Ferrochrome, baghouse dust, zinc, leaching, electrolytic precipitation, hydrometallurgy, solvent extraction, silica, chromium(VI), air pollution. 


\section{Acknowledgements}

1. Francois Friend for his patient guidance during the execution of this project, especially during the writing of the thesis.

2. Personnel from Hernic ferrochrome foundry for supplying raw material for experiments and for the plant visit.

3. Personnel from Waste Tech for information supplied for evaluation of disposal cost. 


\section{Contents}

Synopsis

Acknowledgements

i

List of symbols

List of tables

List of figures

ii

v

vi

vii

\section{Chapter 1 Introduction}

Chapter 2 Literature survey

2.1 RAW MATERIAL

2.2 TREATMENT OF BAGHOUSE DUST

2.3 RECOVERY OF ZINC

2.3.1 Leaching with sulphuric acid

2.3.3 Electrolytic precipitation

\section{Chapter 3 Experimental}

\section{Chapter 4 Results and discussion}


4.2 PRODUCTION OF A SOLUTION SUITABLE

FOR ELECTROLYTIC PRECIPITATION

4.3 WASTE STREAMS PRODUCED AND THE

TREATMENT THEREOF

4.4 ECONOMIC FEASIBILITY OF ZINC

RECOVERY FROM BAGHOUSE DUST

Chapter 5 Conclusions and Recommendations

References

Appendix A Raw data for the first set of experiments

Appendix B Raw data for the second set of experiments

B-1 


\section{List of symbols}

D

HA

$\mathrm{K}_{\mathrm{A}}$

$\mathrm{K}_{\mathrm{ex}}$

$\mathrm{K}_{\mathrm{f}}$

n

$P_{\mathrm{HA}}$

$\rho_{\text {Man }}$

Distribution coefficient

Concentration of acidic extractant in organic phase

Acidity coefficient of the extractant

Extraction coefficient

Formation coefficient of the metal complex with the extractant

Charge on a metal ion

Partition coefficient

Partition coefficient of metal complex 


\section{List of Tables}

2.1 Analysis of dust from Hernic ferro-chromium foundry.

2.2 The influence of various ions on the electrolytic precipitation of zinc.

3.1a Experimental conditions for the first set of experiments

3.1b Experimental conditions for the second set of experiments

4.1 Concentration of metals in the filtrate for 6 hours leaching in the second step, for the first and second set of experiments.

4.2a Concentrations in the filtrate of experiments on the influence of temperature.

4.2b Concentrations in the filtrate of experiments on the influence of temperature.

$4.3 \mathrm{~b}$ Concentrations of metals in the filtrate of experiments performed with different volumes of water added.

4.3c Concentrations of metals in the filtrate with an initial acid concentration of $414 \mathrm{~g} / \mathrm{l}$.

4.3d Concentrations of metals in the filtrate with various initial acid concentrations.

4.4 Unit costs, purity and utilization efficiency for chemicals as used in the calculations of cost (Crest Chemicals, 2001).

A.1 Conditions for the first set of experiments.

A.2 Concentrations of metals in filtrate after leaching $(\mathrm{mg} / \mathrm{l})$.

A.3 Percentage extraction efficiency of metals during leaching.

A.4 Analyses of zinc in the filtrates produced.

A-4

A.5 Analyses of aluminium in the filtrates produced.

A-5

A.6 Analyses of gallium for the filtrates produced.

A-6

A.7 Analyses of iron for the filtrates produced.

A-7

A.8 Analyses of magnesium for the filtrates produced.

A-8

B.1 Conditions for the second set of leaching experiments.

B-1

B.2 Concentration of metals in filtrate after leaching $(\mathrm{mg} / \mathrm{l})$.

B-2

B.3 Percentage extraction of metals during leaching.

B-3

B.4 Analyses of zinc in the filtrates produced.

B-4

B.5 Analyses of aluminium in the filtrates produced.

B-5

B.6 Analyses of gallium for the filtrates produced.

B-6

B.7 Analyses of iron for the filtrates produced.

B-7

B.8 Analyses of magnesium for the filtrates produced.

B-8 


\section{List of Figures}

2.1 Primary treatment of baghouse dust

2.2 Recovery of zinc through hydrometallurgy (secondary treatment of baghouse dust)

2.3 Extraction of zinc, viewed as three circuits, during secondary treatment of the baghouse dust.

2.4 A Pachucha leaching tank utilizing compressed air for agitation.

2.4 Selective extraction of metals from sulphate media with D2EHPA at different $\mathrm{pH}$ levels.

3.1 Schematic representation of the experimental set up for the second leaching step.

3.2 Picture of experimental set-up.

4.1a The effect of duration of leaching on extraction efficiency (first set of experiments).

4.1b The effect of duration of leaching on extraction efficiency (second set of experiments).

4.2a The effect of temperature of leaching on the extraction efficiency (first set of experiments).

4.2b The effect of temperature of leaching on the extraction efficiency (second set of experiments).

4.3a The effect of volume of water added during leaching on the extraction efficiency (first set of experiments).

4.3b The effect of volume of water added during leaching on the extraction efficiency (second set of experiments).

4.3c The effect of initial acid concentration (first step of leaching) on extraction efficiencies (first set of experiments).

4.3d The effect of initial acid concentration (first step of leaching) on extraction efficiencies (second set of experiments).

A.1 Calibration curve for zinc concentration against absorbance.

A.2 Calibration curve for alluminium concentration against absorbance.

A.3 Calibration curve for gallium concentration against absorbance.

A.4 Calibration curve for iron concentration against absorbance.

A.5 Calibration curve for magnesium concentration against absorbance.

B.1 Calibration curve for zinc concentration against absorbance.

B.2 Calibration curve for alluminium concentration against absorbance.

B.3 Calibration curve for gallium concentration against absorbance.

B.4 Calibration curve for iron concentration against absorbance.

B-10

B.5 Calibration curve for magnesium concentration against absorbance.

B-11 


\section{Chapter 1}

\section{Introduction}

The wide use of stainless steel products, due to its resistance to corrosion and adverse conditions, has made the mining of chromite ore and the production of ferrochrome metals prevalent in South Africa today. Stainless steel consists of iron, chromium, nickel and other minor elements. The chromium in stainless steel come from ferrochrome and recycled stainless steel.

Ferrochrome is manufactured at ferrochrome foundries in electric arc furnaces. The feed to electric arc furnaces is chromite ore and can be presented as (Fe,Mg)O.(Cr,Fe,AL) $)_{2} \mathrm{O}_{3}$ (Kirk-Othmer, 1993). The chromium and iron react with carbon, charged to the furnace, and are reduced to form the metal product. Silica $\left(\mathrm{SiO}_{2}\right)$ is also charged to the furnace as a fluidizing agent. The other metal oxides fed to the reactor, as part of the ore, are more volatile and a certain fraction of these metals evaporate, to be condensed again when the off gas is cooled (Stegemann, 2000). The silica also evaporates and condenses again (Omori, 1987). The condensed particles form a very fine dust that is captured in baghouse filters. The particles are very small and could enter the respiratory system of humans and animals. It also contains hexavalent chromium, which is toxic to humans and animals as well as being carcinogenic to humans (Nriagu and Nieboer, 1988).

The captured dust has to be disposed of in a safe and environmentally friendly manner. The $\mathrm{Cr}^{6+}$ is reduced to $\mathrm{Cr}^{3+}$ and precipitated as $\mathrm{Cr}(\mathrm{OH})_{3}$ by raising the $\mathrm{pH}$ (Nriagu and Nieboer, 1988). The $\mathrm{Cr}(\mathrm{OH})_{3}$ slag is a safe product to use as landfill because it is insoluble in water and is not toxic or carcinogenic. During disposal of the dust, the zinc and other metal oxides in the dust go to waste and can also pollute waterways.

At the Hernic ferrochrome foundry near Brits, approximately $3600 \mathrm{~kg}$ dust is formed per day (Strobos and van Zyl, 1997). Due to the process of evaporation and condensation of the more volatile components, the concentration of some metal oxides like zinc and magnesium is increased above that of the slag composition. According to an analysis done by Rocklabs (Strobos and van Zyl, 1997), the dust contains, for example, 7,55\% zinc that relates to a total of 99,2 tons zinc per annum. No attempt is currently being made to extract any of the metals to offset the costs associated with the treatment and disposal of the baghouse dust.

The objectives of this investigation are to determine the optimum conditions for leaching of zinc from baghouse dust and to assess if treatment and disposal costs associated with this dust can be decreased due to recovery of zinc. The method of zinc recovery focuses on the hydrometallurgical route, which includes leaching, solution purification and metal precipitation. A process to purify the leached solution will be selected which will be evaluated based on published literature to determine if 
the leaching process is feasible. The experiments were performed at laboratory scale. An economic evaluation to assess if savings will result will be presented.

Chapter 2 consists of a literature survey that addresses the raw material and the method of zinc recovery. Chapter 3 describes the experiments to determine leaching conditions and in Chapter 4 the results is discussed in terms of the optimum leaching conditions and economic implications. Chapter 5 contains concluding remarks regarding the optimum leaching conditions and economic feasibility and recommendations with regard to further test work. 


\section{Chapter 2}

\section{Literature Survey}

The extraction of zinc from baghouse dust emanating from the ferrochrome industry is investigated in this dissertation. In order to plan the relevant laboratory experiments, information was gathered on the raw material utilised and general conditions for the recovery of zinc.

\subsection{RAW MATERIAL}

For better understanding of the experiments presented in this dissertation, it is important to know what the nature of the raw material utilised was, what compounds it consist of and what the characteristics and values of these compounds are.

The raw material is a baghouse dust emanating from the electric arc furnaces at Hernic ferrochrome foundry, situated near Brits in the North West Province. These furnaces are operated at temperatures in excess of $1500^{\circ} \mathrm{C}$ (Nriagu and Nieboer, 1988). A typical analysis of this particular baghouse dust is given in Table 2.1.

Table 2.1 Analysis of dust from Hernic ferrochrome foundry.

\begin{tabular}{|c|c|}
\hline Component & Percentage \\
\hline $\mathrm{SiO}_{2}$ & 45,21 \\
\hline $\mathrm{Fe}$ & 2,33 \\
\hline $\mathrm{Al}$ & 5,62 \\
\hline $\mathrm{Mg}$ & 13,29 \\
\hline $\mathrm{Na}$ & 5,94 \\
\hline $\mathrm{K}$ & 3,06 \\
\hline $\mathrm{Cr}$ & 3,18 \\
\hline $\mathrm{S}$ & 3,4 \\
\hline $\mathrm{Zn}$ & 7,55 \\
\hline $\mathrm{Pb}$ & 0,123 \\
\hline $\mathrm{Ga}$ & 0,035 \\
\hline
\end{tabular}

A fraction of the chromium present is in hexavalent form. This form of chromium, depending on the relevant dosage, is both toxic and carcinogenic when ingested (Nriagu and Nieboer, 1988). Due to its high solubility in water, it can also pollute waterways through precipitation and seepage. This is the main reason the dust is removed from air streams emitted from ferrochrome foundries. In addition to chromium present in the dust, valuable compounds such as zinc (in the form of $\mathrm{ZnO}$ ), aluminium (in the form of $\mathrm{Al}_{2} \mathrm{O}_{3}$ ) and gallium (in the form of $\mathrm{GaO}$ ) are also present, and the extraction of these metals may be an additional incentive for treatment of the dust. 


\subsection{TREATMENT OF BAGHOUSE DUST}

The baghouse dust removed from ferro chrome foundries in South Africa is normally disposed off on ad hoc disposal sites situated on the relevant foundry property. Prior to disposal the dust is usually treated with a ferrous compound (for example, ferrous suphate) to reduce the hexavalent chromium present in the dust. A shallow layer of topsoil normally covers the disposal sites in an effort to prevent groundwater pollution through seepage. However, due to present and future environmental regulations, the above practice can no longer be accepted and alternative solutions are currently investigated in South Africa (Beukes et al.,1999).

One such a solution was proposed by Strobos and Van Zyl (1997) and is shown in Figure 2.1. The first step for the treatment of the baghouse dust requires mixing it with water to dissolve all soluble compounds. The subsequent slurry is separated via filtration into solid (filter cake) and liquid (filtrate) phases. The filter cake can be either dumped at a waste disposal site or utilized for metal recovery. The utilization of the filter cake for recovering of valuable metals, and more particularly zinc, forms the basis of this dissertation and will be discussed in detail in Section 2.3. Although the treatment of the filtrate, to prevent contamination of natural waters, is not included in this dissertation, it is briefly outlined below to complete the overview on the treament of baghouse dust.

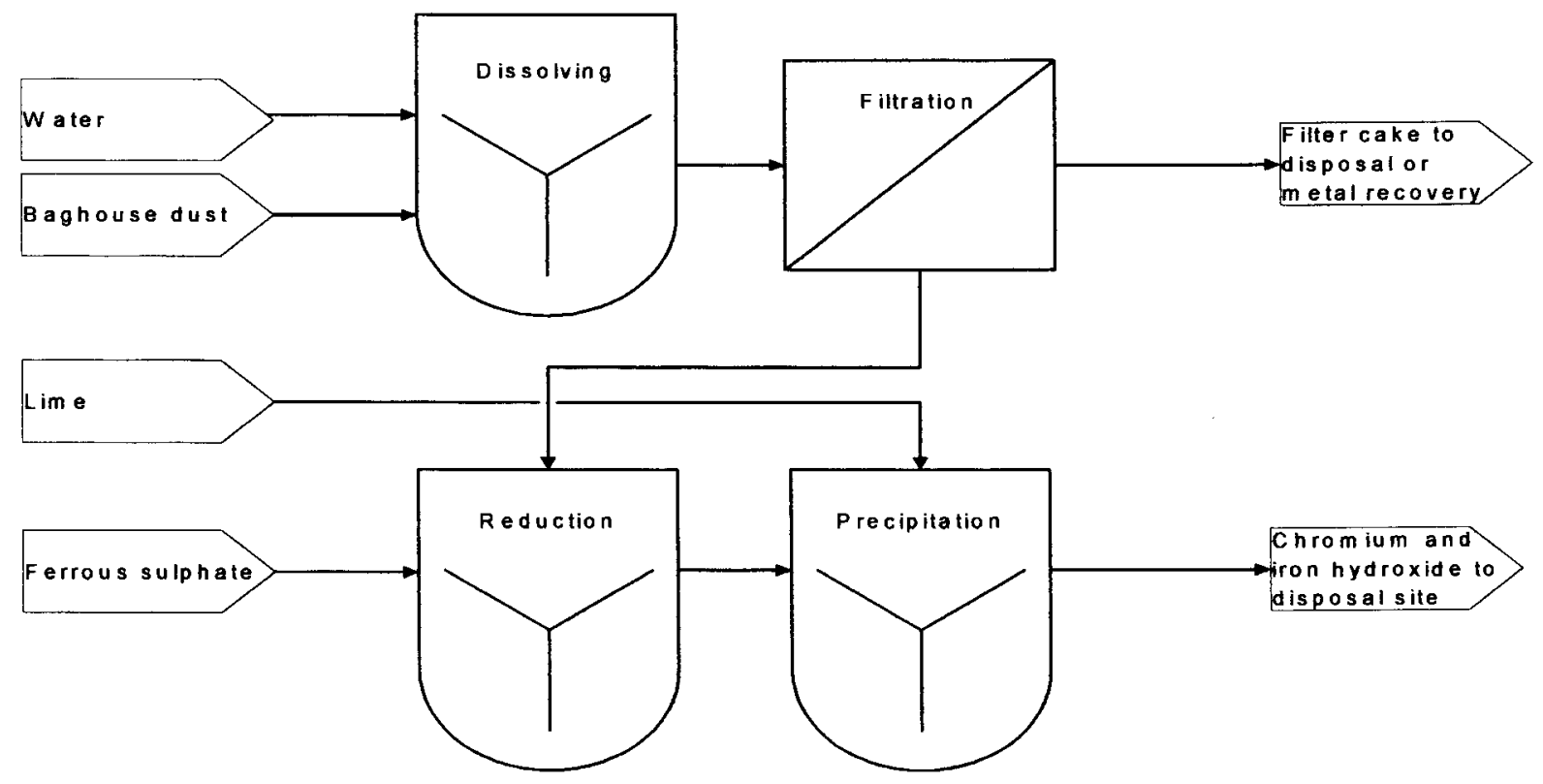

Figure 2.1 Primary treatment of baghouse dust.

For the treatment of the filtrate, toxic hexavalent chromium can be reduced to its less toxic tri valent form, through the use of reducing agents described by Nriagu and Nieboer (1988). These include ferrous sulphate, sodiumbisulphate, sulphur dioxide, sodium hydrosulphate and sulphide waters. When ferrous sulphate is added to the filtrate, the following redox reaction will result (Nriagu and Nieboer, 1988):

$$
3 \mathrm{Fe}^{2+}+\mathrm{CrO}_{4}^{2-}+4 \mathrm{H}_{2} \mathrm{O} \Leftrightarrow 3 \mathrm{Fe}^{3+}+\mathrm{Cr}^{3+}+8 \mathrm{OH}^{-}
$$


The $\mathrm{Cr}^{3+}$ can then be immobilized by precipitating it as $\mathrm{Cr}(\mathrm{OH})_{3}$. The relevant hydrolysis reaction for $\mathrm{Cr}^{3+}$, which takes place during hydrated lime dosing at a $\mathrm{pH}$ of between 6 and 9 , is as follows:

$$
\mathrm{Cr}^{3+}+3 \mathrm{H}_{2} \mathrm{O} \Leftrightarrow \mathrm{Cr}(\mathrm{OH})_{3}+3 \mathrm{H}^{+}
$$

The subsequent hydroxide can then be disposed of in a general landfill site, together with an excess of lime (Kirk-Othmer, 1993).

\subsection{RECOVERY OF ZINC}

The filter cake obtained from the filtration step in Figure 2.1 (primary treatment) contains the insoluble metal oxides that were initially present in the dust. Strobos and Van Zyl (1997) reported that approximately $10 \%$ (on a weight basis) of the initial baghouse dust is lost through dissolution and are subsequently separated from the dust as part of the filtrate. The most abundant compounds still present in the filter cake are silica, magnesium oxide, aluminium oxide and zinc oxide. Based on the relative simple process for the extraction of zinc from solid compounds (Evans and De Jonghe, 1991) and its high monetary value, this dissertation investigates the technical and economic feasibility of recovering zinc from these waste materials generated at ferrochrome industries.

Two different means of extracting metals from a raw material exist, namely pyro- metallurgy and hydrometallurgy. During pyro-metallurgy metal oxides react with carbon in the absence of oxygen to form $\mathrm{CO}_{\mathrm{x}}$ and the metal. With hydrometallurgy the following processes take place: the metal oxide is dissolved with acid into an ionic form (leaching), the solution is refined (for example, through solvent extraction and stripping of the required metal), and the pure metal precipitated. Due to the environmentally clean and energy efficient nature of the hydrometallurgy method, as well as availability of reagents and laboratory equipment, it was decided to extract zinc by means of hydrometallurgy.

The extraction of zinc from the filter cake (obtained during primary treatment) through hydrometallurgy is schematically represented in Figure 2.2. The process can be divided into four stages, namely leaching, extraction, stripping and precipitation. During leaching, the sulphuric acid (commonly used in the extraction industry) reacts with the filter cake in a complete mixed reactor. The reactor contents are then filtered and the subsequent filtrate contains zinc and other elements such as iron, magnesium and aluminium. The filter cake from this secondary treatment, consisting of mainly silica and other undissolved metal oxides, is normally disposed of on a landfill site.

The next step, electrolytic precipitation (electrolysis), is the most common process utilized for the recovery of zinc from solutions in the metallurgy industry (Evans and De Jonghe, 1991). However, for successful recovery of zinc through electrolysis, substances that will interfere with the precipitation process will have to be removed to very low concentrations (Gill, 1980; Ritcey and Ashbrook, 4979). The above implies that a purification step is required to reduce the concentrations of interfering substances. However, in order to sustain a sufficient rate in the electrolytic precipitation cells, an optimum zinc concentration is also required. These criteria are addressed by solvent extraction; a process commercially used for the production of, inter alia, zinc sulphate solutions (Klocker et al., 1997). 


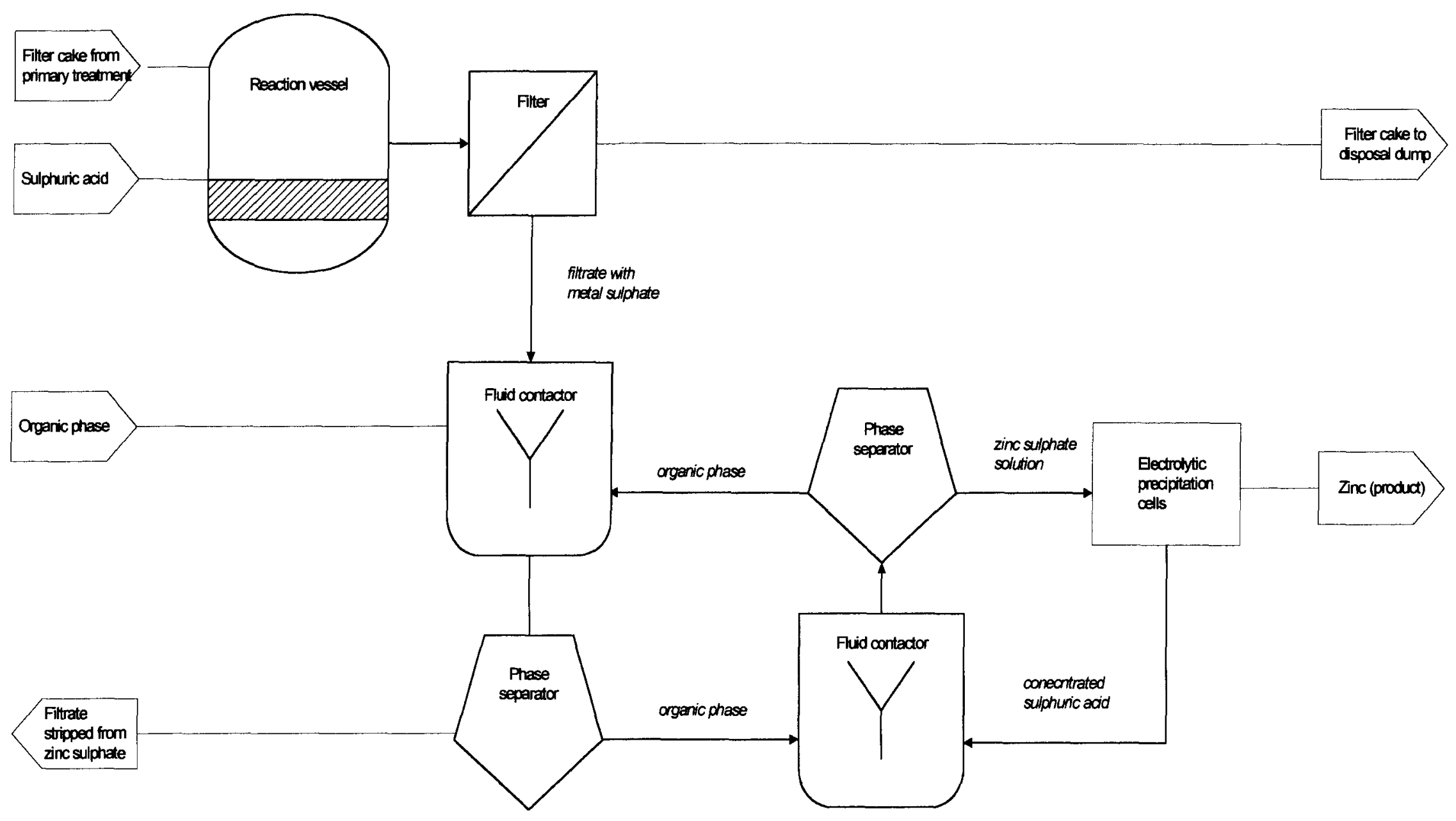

Figure 2.2 Recovery of zinc through hydrometallurgy (secondary treatment of baghouse dust). 
During solvent extraction the filtrate from the leaching step is treated with an acidic extracting agent, di(-2-ethylhexyl) phosphoric acid, dissolved in an organic carrier (nheptane), and zinc ions are transferred from the aqueous to the organic phase. The organic and aqueous phases are then separated in a phase separation unit. The filtrate, depleted of zinc ions and enriched with $\mathrm{H}^{+}$, can be recycled to the leaching step after neutralization and removal of excessive dissolved substances. During stripping the organic phase that was loaded with zinc ions during solvent extraction, is contacted with a concentrated sulphuric acid stream. Zinc ions are transferred from the organic to the aqueous phase, followed by separation of the two phases. Transfer of the ions between the two phases take place in complete mixed reaction vessels.

The subsequent concentrated zinc sulphate stream is then fed to the electrolytic precipitation cells. An electrical current is passed through the zinc sulphate solution causing the metal ions to be reduced to an oxidation state of zero, the elemental form of the metal. Through the precipitation of zinc in its elemental form, the zinc sulphate solution is converted to sulphuric acid that can be recycled to the solvent extraction unit. Ulman et al. (1998) summarised the above recovery of zinc to three circuits, as illustrated in Figure 2.3. The three circuits (linked by the leaching, extraction, stripping and precipitation stages) are:

- The leaching circuit $(L C)$ : the acid stream is recycled after treatment.

- The solvent extraction circuit (SEC): the organic phase is recycled and act as carrier of the zinc between the two aqueous circuits.

- The electrolytic precipitation circuit (EPC): the concentrated zinc sulphate solution is recycled after regeneration through contacting the depleted solution with the loaded organic phase.

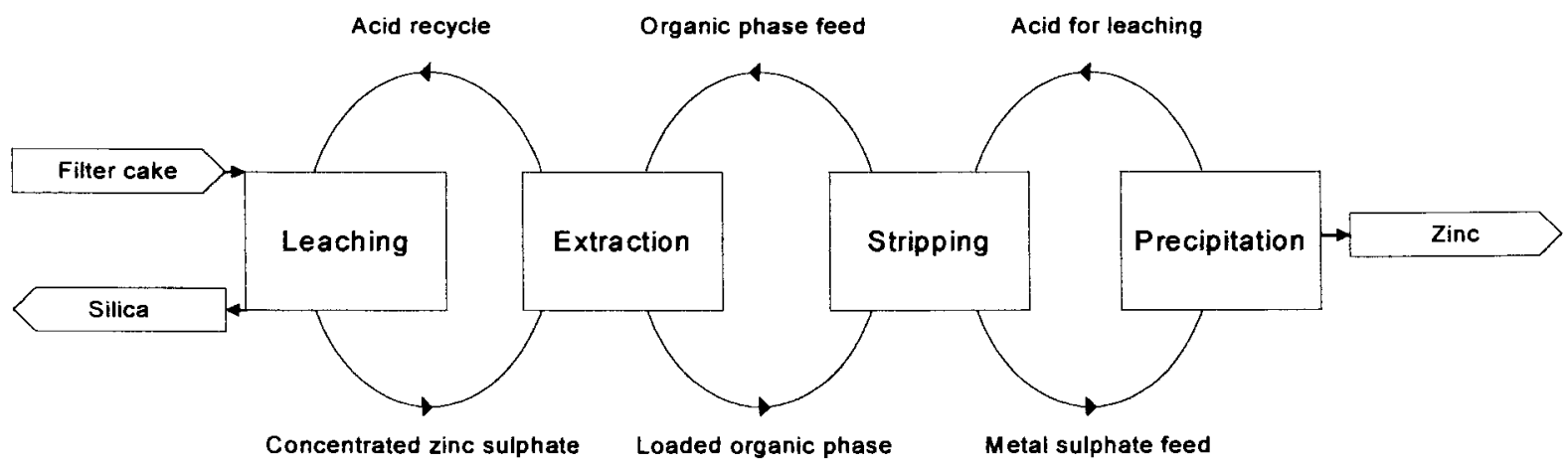

Figure 2.3 Extraction of zinc, viewed as three circuits, during secondary treatment of the baghouse dust.

In the following section, general principles applicable to leaching are discussed which will form the basis for the experiments. 


\subsubsection{Leaching with sulphuric acid}

The rate of leaching is affected by a number of factors and optimum conditions for the extraction of zinc are determined thereby. This includes particle size, the nature of the solvent, temperature and agitation.

- Particle size influences extraction whereby smaller particle sizes result in greater interfacial area between the relevant solid and liquid. The diffusion path of the solute through the porous structure of the residual solids is also shorter. Small particles may, however, impede circulation of the liquid and separation of the particles from the liquid, making subsequent drainage of the solid residues more difficult. Even distribution of particle size is desired as this may lead to uniform time of extraction and minimal obstruction to solvent flow (Coulson and Richardson, 1996).

- The solvent should be a selective solvent and its viscosity should be sufficiently low for it to circulate freely. It was reported by Zeydabadi et al. (1998) that through varying the concentration of the sulphuric acid fed to the leaching step, and also the acid to raw material ratio, zinc could be leached out preferentially to other metals. The initial rate of extraction for all the components is the highest, due to the high concentration of the pure solvent. Therefore the initial quantities of material fed to the leaching vessel need to be controlled accurately, to ensure selection of zinc. The rate will decrease due to concentration gradients and changes in the viscosity of the solvent.

- An increase in temperature will increase the solubility of the materials that are being extracted, to give a higher rate of extraction. The diffusion coefficient will be expected to increase with temperature as well.

- Agitation (stirring) of the fluid is important because it prevents sedimentation and allows more effective use of the interfacial surface (Coulson and Richardson, 1996). An optimum rate for agitation can be obtained to the point where an increase in agitation rate does not increase the rate of extraction. This is due to the bulk concentration and the concentration at the surface of the solid being the same. The effect of bulk diffusion is then eliminated and if the particles are small, for example a powder, the rate of extraction can be accounted for by the rate of dissolution of the desired compounds.

From large scale leaching operations, valuable information can be gathered about what the optimum conditions should be for the extraction of zinc. Commercially both batch and continuous processes are employed.

During continuous process leaching, zinc is leached through a two-step, counter-flow configuration. The zinc is leached at a temperature of approximately $95^{\circ} \mathrm{C}$ (Gill, 1980). It is practically difficult to increase the temperature above this because it is close to the boiling point of the liquid. To increase the temperature above this the system will have to be under increased pressure. The first contact step is with concentrated sulphuric acid of approximately $200 \mathrm{~g} / \mathrm{l}$. The reaction time is approximately two hours and the free acid concentration drops to $5 \mathrm{~g} /$ l. During this time, 50 to 75 percent of the soluble zinc present in the raw material is dissolved (Gill, 1980). 
Batch process leaching of zinc oxide is not as commonly used as the continuous process, because of its smaller capacity. However, it does have certain advantages, for example, zinc ferrites $\left(\mathrm{ZnO}-\mathrm{Fe}_{2} \mathrm{O}_{3}\right)$ which are formed during roasting and are insoluble during normal leaching, can be processed. The zinc ferrites are formed at temperatures in excess of $650^{\circ} \mathrm{C}$ that can easily be reached in electric arc furnaces where ferro chromium is produced. Therefore the batch leaching process will be more suitable for extraction of zinc from the dust formed in electric arc furnaces than, for example, leaching of zinc oxide formed through heating zinc sulphide. Another advantage is that each batch of the feed is individually treated and deviation from a standard feed's analysis can be accommodated (Gill, 1980). The heat of reaction of the decomposition of the ferrites raises the solution temperature to $106{ }^{\circ} \mathrm{C}$. A considerable amount of water is evaporated as steam and is removed via stacks.

In order to cause all the above-mentioned conditions to be met during leaching, the most suitable equipment has to be selected. Equipment used during leaching includes agitators and different types of leaching tanks. One precaution during agitation is to prevent high rates of agitation, which result in little movement of the solid particles relative to the liquid. Therefore agitation may be achieved by means of compressed air rather than mechanical stirrers. One example of a leaching vessel which accommodates agitation by compressed air, is a Pachuca leaching tank. Air is blown through a pipe, which enters the tank just above the solution level, and extends to the bottom of the tank where it opens. The air bubbles released from the pipe decrease the density of the slurry (see Figure 2.4). These leaching tanks are fairly efficient and used throughout the world (Coulson and Richardson, 1996). Tanks used for both batch and continuous leaching processes are the same.

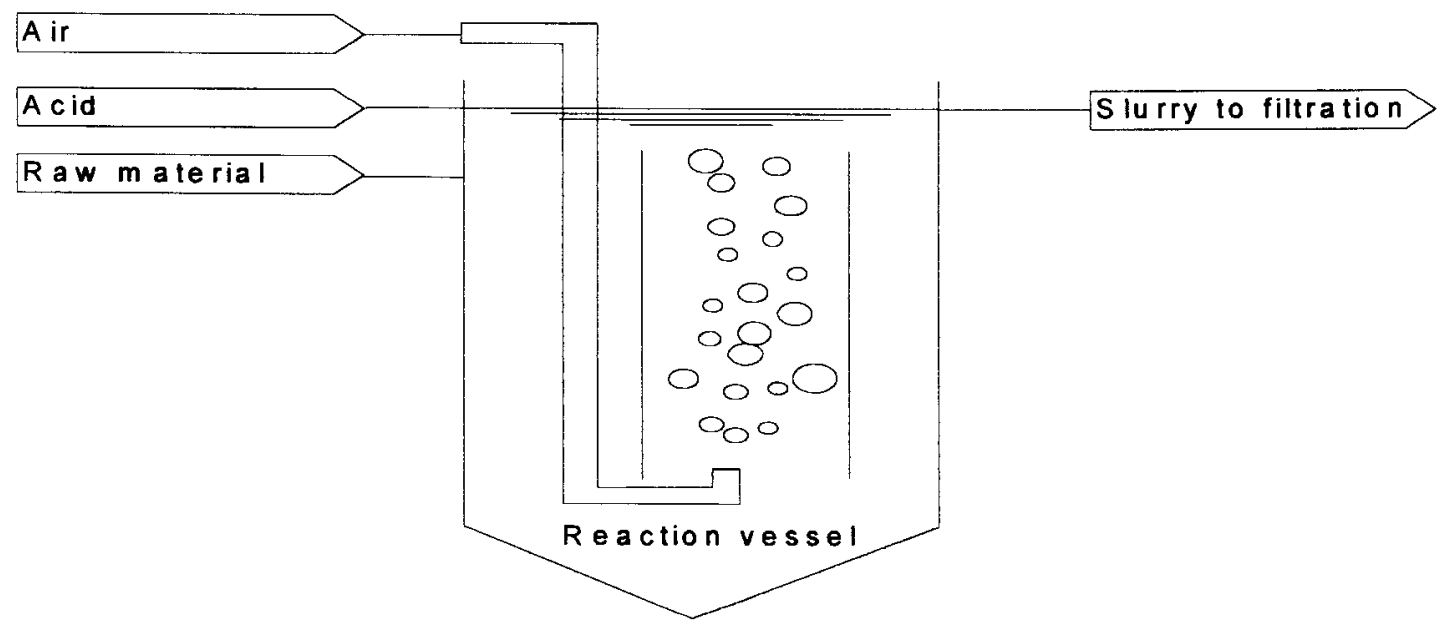

Figure 2.4 A Pachucha leaching tank utilizing compressed air for agitation.

After leaching, the filtrate is treated via solvent extraction in order to:

- produce a product stream with mainly zinc sulphate and sulphuric acid with little other metal impurities, and

- to increase the concentration of zinc in the feed to the electrolytic precipitation plant. 


\subsubsection{Solvent extraction}

During this process an organic solution (n-heptane), containing an optimum concentration of di-(2-ethylhexyl)-phosphoric acid (D2EHPA), is contacted with the filtrate produced in Section 2.3.1. Intensive mixing is required to establish sufficient contact between the organic and aquatic phases. Zinc is transferred from the aquatic to the organic phase through the following reaction (Klocker et al., 1997):

$$
\begin{aligned}
& \mathrm{Zn}^{2+}+1.5 \mathrm{R}_{2} \mathrm{H}_{2} \Leftrightarrow \mathrm{ZnR}_{2}(\mathrm{RH})+2 \mathrm{H}^{+} \\
& \text {with } \mathrm{R}=2 \text {-ethylhexyl }
\end{aligned}
$$

D2EHPA is an acidic extractant and the extraction process entails the exchange of cations between the organic phase and the aqueous phase. $\mathrm{H}^{+}$ions move from the organic to the aqueous phase and $\mathrm{Zn}^{2+}$ from the aqueous to the organic phase. The long carbon chains attached to the phosphorous acid prevent it from being dissolved in the aqueous phase and it thus remains in the organic phase (n-heptane). The effect of different parameters on the extraction can be quantified by the equation (Ullmann et al., 1988: 6-45):

$$
\log \mathrm{D}=\log K_{e x}+n \log [\mathrm{HA}]+n \mathrm{pH}
$$

D is the distribution coefficient and $K_{e x}$ is the extraction coefficient. HA is the concentration of the acidic extractant in the organic phase. A plot of $\log \mathrm{D}$ against $\mathrm{pH}$ at constant reagent concentration should give a straight line with slope $n$, the charge on the metal ion. The extraction constant $K_{e x}$ has the form (Ullmann et al., 1988):

$$
K_{e x}=p_{\mathrm{HA}}^{-\mathrm{n}} K_{\mathrm{A}}{ }^{\mathrm{n}} \mathrm{K}_{\mathrm{f}} p_{\mathrm{Man}}
$$

It includes the partition coefficient $p_{\mathrm{HA}}$, the acidity coefficient $K_{\mathrm{A}}$ of the extractant, the overall formation coefficient of the metal complex with the extractant $K_{f}$ and its partition coefficient $p_{\text {Man }}$. The relative magnitude of $K_{\mathrm{f}}$ determines the amount of metal extracted at a defined reagent concentration and $\mathrm{pH}$. Thus metals with high $K_{\mathbf{f}}$ values are extracted at lower $\mathrm{pH}$ than metals with lower $K_{\mathrm{f}}$ values (Ullmann et al., 1988).

By changing the $\mathrm{pH}$ of the feed to the contact step between the organic and the aqueous phase, a specific ion can be extracted because different ions have different $K_{\mathrm{f}}$ values. For example, zinc is extracted at a $\mathrm{pH}$ between 1 and 2, while magnesium is extracted in the region of $\mathrm{pH} 5$ to 7 (McKetta, 1984). This shows that a good selectivity of extraction between zinc and magnesium can be obtained. Figure 2.5 shows how zinc is preferentially transferred from the aqueous to the organic phases with respect to other metal ions in solution at different $\mathrm{pH}$ levels (McKetta, 1984).

Once the metal ions have been taken up into the organic medium, it can be stripped from the organic phase by contacting the organic phase with concentrated sulphuric acid (Zeydabadi $e t$ $a l ., 1997)$ and effluent from the electrolytic precipitation cells used for this purpose (Amer $e t$ al., 1995). The concentrated acid solution becomes rich in zinc sulphate through intensive mixing with the organic phase. 


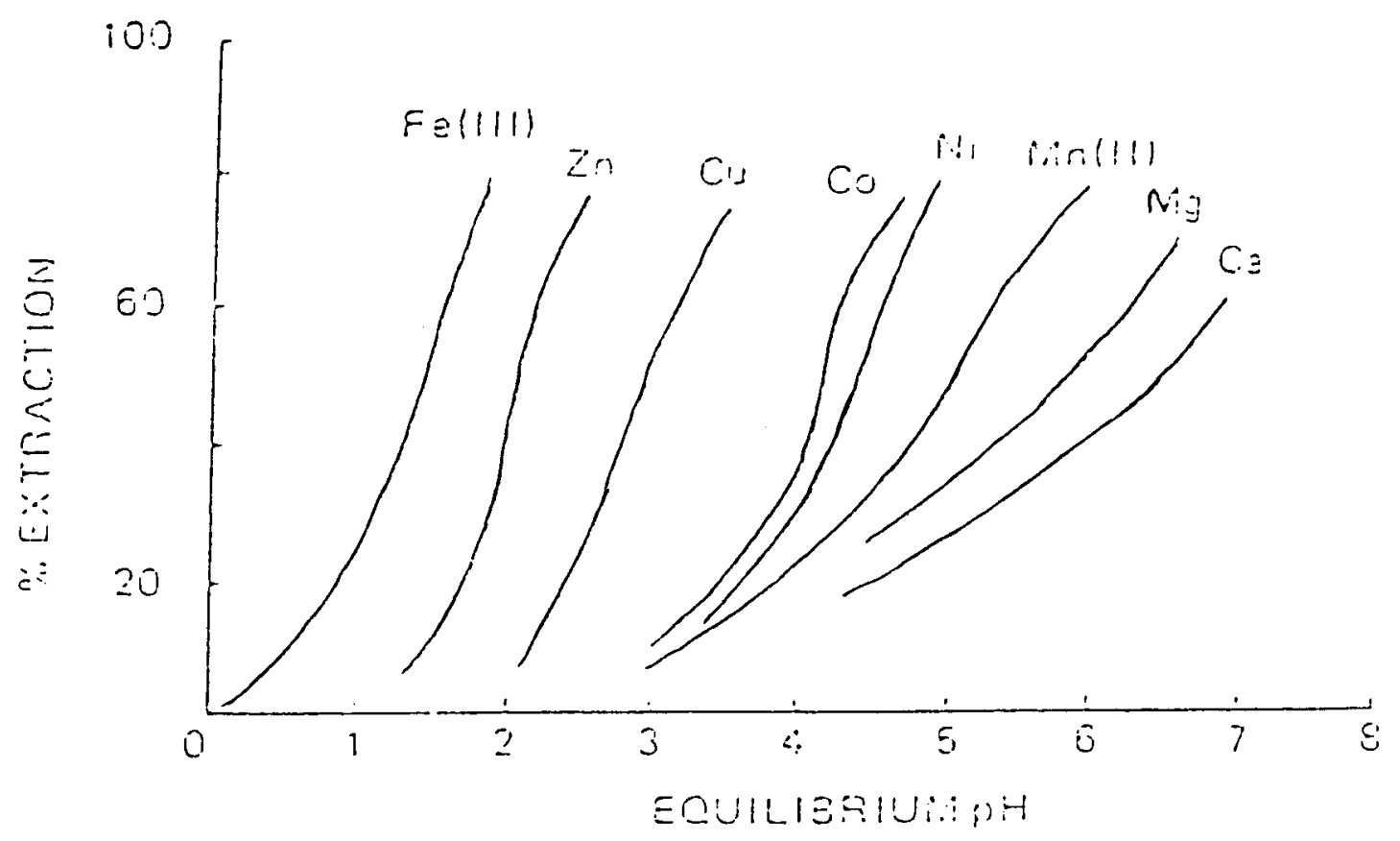

Figure 2.5 Selective extraction of metals from sulphate media with D2EHPA at different $\mathrm{pH}$ levels.

The concentration of zinc in the feed to the electrolytic precipitation cells can be changed by adjusting the ratio between acid used for stripping and the organic phase (Evans and De Jonge, 1991). After stripping, the aqueous solution then forms the feed to the electrolytic precipitation plant.

\subsubsection{Electrolytic precipitation}

During electrolytic precipitation an electric current is passed through a zinc sulphate solution in electrolytic precipitation cells. This results in the conversion of zinc cations to zinc in an oxidation state of zero. Electrolysis must be started with an essentially neutral $\mathrm{ZnSO}_{4}$ solution, and the reaction takes place till approximately half the zinc is deposited. According to Rosenqvist (1983), the feed concentration of zinc to the precipitation plant should be approximately 50 to $150 \mathrm{~g} / \mathrm{l}$. The acid concentration increases to $100 \mathrm{~g} \mathrm{H}_{2} \mathrm{SO}_{4}$ per litre. This solution is returned to the leaching plant or to the solvent extraction plant to be used as strip liquor (Amer et al., 1995). The following reaction takes place during the precipitation:

$$
\mathrm{ZnSO}_{4}+\mathrm{H}_{2} \mathrm{O} \Rightarrow \mathrm{Zn}+\mathrm{H}_{2} \mathrm{SO}_{4}+1 / 2 \mathrm{O}_{2}
$$

The zinc accumulates at the cathodes and must be stripped every 24 to 48 hours. The cathodes are made from titanium and the anodes from lead-antimony or lead-silver alloy (Gill, 1980). The temperature must be kept constant at approximately 35 to $45^{\circ} \mathrm{C}$ by circulating cooling water through lead coils placed in each cell. The current density should be approximately 20 to 40 amperes per square foot $\left(0,09 \mathrm{~m}^{2}\right)$ of cathode area. The theoretically required voltage is 
approximately $2,35 \mathrm{~V}$ (Gilchrist, 1989), but in actual fact the voltage used is 3,25 to $3,5 \mathrm{~V}$. This is due to current leakage throughout the electrical circuit.

Current leakage can also be due to other substances in the electrolyte solution (Gill, 1980; Ritcey and Ashbrook, 1979). Various negative effects can result through the presence of these ions, for instance, some of the ions can co-deposit with zinc, causing a decrease in the purity of the zinc product. The current efficiency and electrolyte resistivity can be negatively impacted. The characteristics of the zinc deposits can be altered causing it to either be spongy, beady or perforated. In Table 2.2 the concentrations of certain substances encountered in commercial plants and the possible effects on the quality of the deposited zinc are shown (Kirk-Othmer, 1996).

Table 2.2 The influence of various ions on the electrolytic precipitation of zinc.

\begin{tabular}{|l|c|l|l|l|}
\hline \multicolumn{1}{|c|}{ Impurity } & $\begin{array}{c}\text { Reported } \\
\text { range, } \mathrm{mg} / \mathrm{I}\end{array}$ & \multicolumn{1}{|c|}{$\begin{array}{c}\text { Current } \\
\text { efficiency }\end{array}$} & $\begin{array}{c}\text { Characteristics } \\
\text { of deposit }\end{array}$ & \multicolumn{1}{|c|}{ Comments } \\
\hline Germanium & $0.005-0.2$ & Lowers & Spongy & Worse with cobalt \\
\hline Tellurium & $<0.001$ & Lowers & Uneven & Worse with cobalt \\
\hline Selenium & $<0.002$ & Lowers & Uneven & Worse with cobalt \\
\hline Arsenic & $0.003-0.02$ & Lowers & Corrugated & Worse with cobalt or germanium \\
\hline Antimony & $0.01-0.03$ & Lowers & Beady, poor adhesion & \\
\hline Copper & $0.05-0.2$ & Lowers & & \\
\hline Nickel & $<0.01-0.5$ & Lowers & Holes & \\
\hline Cobalt & $0.03-2.0$ & Lowers & Holes & Reduces lead deposition \\
\hline Tin & $<0.02$ & Lowers & Filmy & May reduce anode corrosion \\
\hline Iron & $0.2-25$ & Lowers & & Deposits with zinc \\
\hline Cadmium & $0.01-5$ & & & Deposits with zinc \\
\hline Lead & 1 & & & Increases lead deposition, \\
\hline Thallium & $0.5-5$ & & & Increases electrolyte resistivity \\
\hline Aluminium & 10 & & & Increases electrolyte resistivity \\
\hline Magnesium & $6.5-12 \mathrm{~g} / 1$ & & & \\
\hline Manganese & $3-3.5 \mathrm{~g} / 1$ & & & \\
\hline
\end{tabular}

The leaching step and the accompanying purification processes, such as solvent extraction, impact on the feed concentrations to the electrolytic precipitation plant. The quality of the feed to the electrolytic precipitation plant is directly influenced by the concentrations of metals in the product from the leaching plant. Ions can be carried over from the leaching circuit to the organic phase and again to the stripping acid if it is leached out from the dust initially (Zeydabadi et al., 1997).

For this dissertation, leaching was studied through extensive laboratory experiments. Solvent extraction and electrolytic precipitation is discussed as part of this literature survey to provide criteria whereby the efficiency of the leaching process and the feasibility of zinc production from the waste product could be established. 


\section{Chapter 3}

\section{Experimental}

Various experiments were performed in order to find the optimum conditions for leaching zinc (using sulphuric acid) from filter cake obtained from the filtration step of the primary treatment described in Chapter 2. These optimum conditions are dependant on the rate of leaching (of zinc), and are determined by a number of factors. These include, inter alia, particle size, rate of agitation, duration of leaching, temperature and the nature of the solvent (Coulson and Richardson, 1991). In the experiments conducted, the effect on the percentage extraction of various metals was determined when changing certain of the variables. All the experiments were batch experiments.

A two-step leaching procedure was followed to prevent the formation of silica gel. During leaching with sulphuric acid, the acid can act as a catalyst for the polymerisation of $\mathrm{SiO}_{2}$ and form silica gel (Kirk-Othmer 1997). The formation of this gel makes it impossible to separate the silica and the dissolved substances by filtration. It is unclear why gel formation did not occur in this instance, but various factors can play a role, for example, salt concentration, $\mathrm{pH}$ and the presence of other metals such as iron. The presence of iron can, for example, retard the dissolution of silica (Kirk Othmer 1997).

The above two-step batch leaching experiments were performed with the apparatus and experimental set up described below.

\subsection{APPARATUS AND EXPERIMENTAL SET UP}

The apparatus used in the first step of leaching included:

- a glass beaker,

- glass rod, and

- a measuring cylinder.

During the first step of leaching concentrated sulphuric acid was added to water and then added to the filter cake in a glass beaker. It was stirred while reacting for approximately 20 minutes. The second step of leaching, whereby the solution is diluted with distilled water, was performed with the following apparatus:

- Erlenmeyer flask,

- hot plate and magnetic stirrer (combined),

- magnet for stirring,

- cooling coil,

- Buchner filter, 
- thermometer,

- $\mathrm{pH}$ meter, and

- an atomic absorption spectrophotometer.

The second step of leaching was performed in an Erlenmeyer flask placed on a hot plate to raise the temperature to $98{ }^{\circ} \mathrm{C}$. The liquid was stirred with a magnetic stirrer. Any water vapour formed was condensed. A thermometer in the glass tube between the Erlenmeyer flask and the condenser measured the temperature of the water vapour. This experimental set up is illustrated in Figure 3.1 and shown in Figure 3.2.

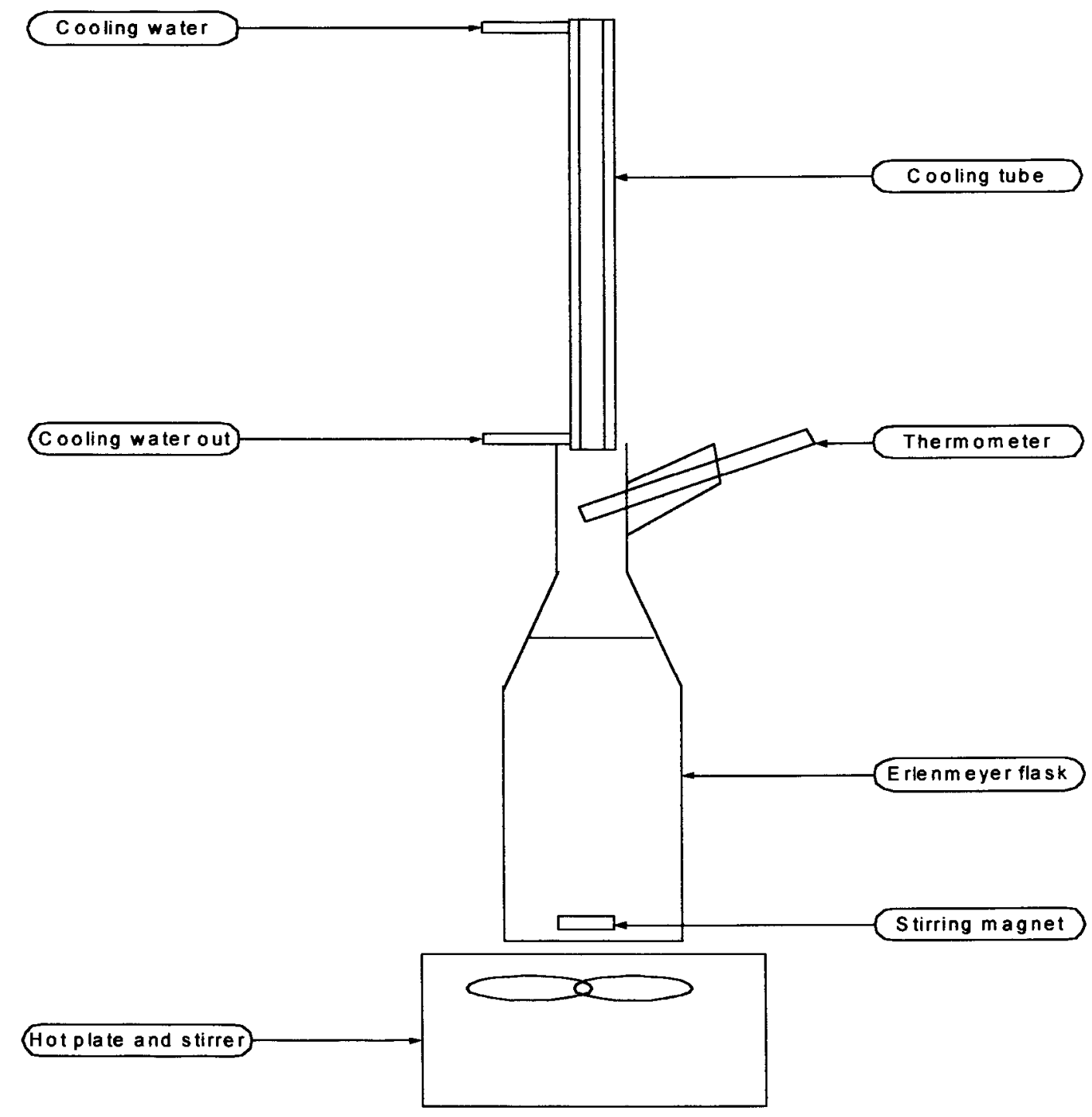

Figure 3.1 Schematic representation of the experimental set up for the second leaching step. 


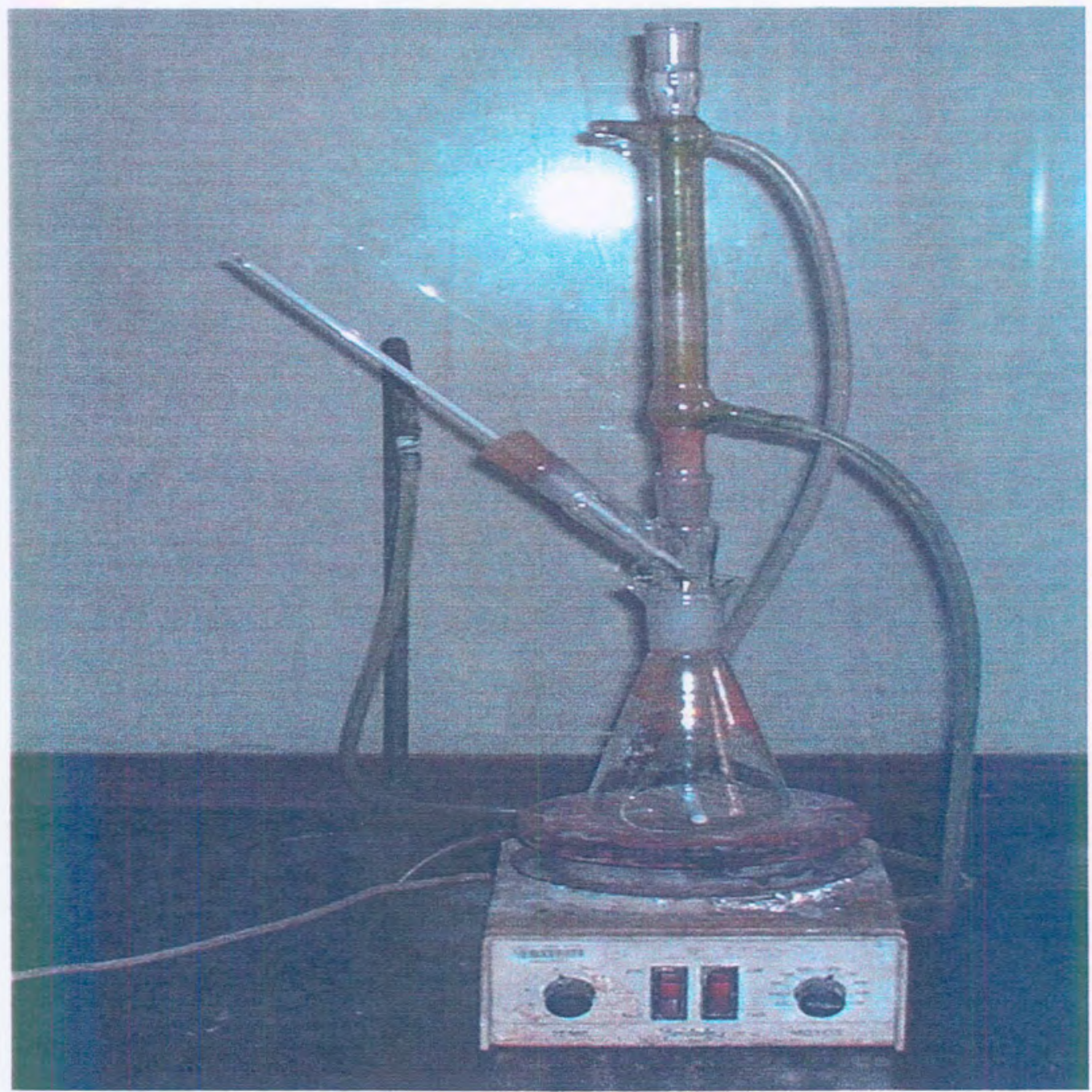

Figure 3.2 Picture of experimental set-up.

\subsection{METHOD AND PLANNING}

Since the filter cake is already in a powder form, no further attempt was made to change the particle size. As discussed by Coulson and Richardson (1991), particle size should be as small as possible, but not so small that drainage of the solid residues becomes difficult to achieve. The rate of agitation was kept constant for all experiments. The variables investigated were the duration of leaching, temperature at which leaching took place and the nature of the solvent.

After the first set of experiments was performed, results were questioned and the experiments repeated (see Chapter 4 for discussion). The conditions were slightly altered for the second set of experiments. The conditions for the second set of experiments will be given in brackets where the ranges of the variables are given. 
During the concentrated acid leaching step, $30(40) \mathrm{ml}$ of distilled water were mixed with $20 \mathrm{ml}$ of concentrated sulphuric acid $(91 \%)$ and added to $30 \mathrm{~g}$ of filter cake. This reaction mixture was stirred with a glass rod for 20 minutes.

In the second leaching step, a further 60 to $260 \mathrm{ml}$ of distilled water were added to prevent diffusion limitations and saturation of the mixture from slowing down or stopping the dissolution reactions (Coulson and Richardson, 1991).

The reaction in the second leaching step took place in a 300-ml Erlenmeyer flask. A magnetic stirrer was used for agitation at a constant speed. Manual adjustment of the hot plate controlled the temperature of the reaction liquor after measurement of both the temperatures of the vapour and the reaction liquor with a thermometer. At completion of leaching, the slurry was filtered with a Buchner filter (Watman $\mathrm{Nr} 1$ filter paper). After filtration, $50 \mathrm{ml}$ of distilled water were used as wash water to remove any leach liquor still present in the filter cake.

The filtrate was analysed with an atomic absorption spectrophotometer to determine the concentration of zinc, iron, gallium, aluminium and magnesium in the filtrate. The percentage recovery for each metal extracted cake was calculated. The filter cake was dried and the weight of the filter cake determined.

For the different parameters investigated, slightly different reaction conditions were used that is summarised below.

\subsubsection{Duration of leaching}

The effect of duration of leaching on the extraction efficiencies of various metals was evaluated by varying the duration of the second leaching step between 0 and 72 hours. All other conditions were kept constant, namely

- $30 \mathrm{~g}$ of filter cake,

- sulphuric acid concentration of 132 (151) g/l (based on initial charge of free acid),

- rate of agitation,

- volumes of $200(160) \mathrm{ml}$ water and $20 \mathrm{ml}$ sulphuric acid, and

- temperature of $98^{\circ} \mathrm{C}$.

\subsubsection{Temperature during leaching}

The effect of temperature during leaching on the extraction efficiencies of various metals was evaluated by varying the temperature during the second leaching step between 25 and $98{ }^{\circ} \mathrm{C}$ (Gill, 1980). At $98{ }^{\circ} \mathrm{C}$ the reaction liquor was boiling and water had to be condensed. All other conditions were kept constant:

- duration of 24 hours,

- $30 \mathrm{~g}$ filter cake,

- sulphuric acid concentration of 132 (152) g/l (based on initial charge of free acid),

- rate of agitation, and

- volumes of $200(160) \mathrm{ml}$ water and $20 \mathrm{ml}$ sulphuric acid. 


\subsubsection{Concentration of sulphuric acid}

This variable was investigated by first of all keeping the acid to filter cake ratio constant (A) during the first step of leaching and changing the volume of water added for the second step. The volume of water added during the second step varied between 60 and $260 \mathrm{ml}$. The following variables were kept constant for each experiment (Zaydabadi et al., 1998):

- duration of 24 hours,

- sulphuric acid concentration in second step 132 (152) g/l (based on initial charge of free acid),

- $30 \mathrm{~g}$ filter cake,

- rate of agitation, and

- temperature of $98^{\circ} \mathrm{C}$.

Thereafter (B) the mass of sulphuric added was varied between 8,37 and 33,5 $\mathrm{g}$ (Gill, 1980; Zaydabadi et al., 1998) and therefore the acid to dust ratio from 0,28 to 1,12 . Once again the duration, original mass of filter cake, rate of agitation and temperature were kept constant. In this case the volume of water added during the second step also remained constant at 200 (160) $\mathrm{ml}$.

Table 3.1a and 3.1b summarise the experimental conditions for the first and second set of experiments for the different parameters investigated.

Table 3.1a Experimental conditions for the first set of experiments

\begin{tabular}{|l|c|c|c|c|}
\hline $\begin{array}{c}\text { Parameter } \\
\text { Investigated }\end{array}$ & Duration & Temperature & $\begin{array}{c}\text { Concentration } \\
\text { of } \mathrm{H}_{2} \mathrm{SO}_{4}(\mathrm{~A})\end{array}$ & $\begin{array}{c}\text { Concentration } \\
\text { of } \mathrm{H}_{2} \mathrm{SO}_{4}(\mathbf{B})\end{array}$ \\
$\begin{array}{l}\text { Experimental } \\
\text { Conditions }\end{array}$ & $0-72$ & 24 & 24 & 24 \\
\hline $\begin{array}{l}\text { Duration (hours)-2 } \\
\text { step }\end{array}$ & 30 & 30 & 30 & 30 \\
\hline Filter cake mass (g) & 1,12 & 1,12 & 1,12 & $0,28-1,12$ \\
\hline Acid to dust ratio & 662 & 662 & 662 & $414-662$ \\
\hline $\begin{array}{l}\mathrm{H}_{2} \mathrm{SO}_{4} \text { concentration } \\
(\mathrm{g} / \mathrm{l})-1^{\text {st }} \text { step }\end{array}$ & 132 & 132 & $106-208$ & $69-132$ \\
\hline $\begin{array}{l}\mathrm{H}_{2} \mathrm{SO}_{4} \text { concentration } \\
(\mathrm{g} / \mathrm{l})-2^{\text {nd }} \text { step }\end{array}$ & 200 & 200 & $95-260$ & 200 \\
\hline $\begin{array}{l}\text { Volume of water (ml) } \\
2^{\text {nd }} \text { step. }\end{array}$ & 98 & $25-98$ & 98 & 98 \\
\hline $\begin{array}{l}\text { Temperature }\left({ }^{\circ} \mathrm{C}\right) \\
2^{\text {nd }} \text { step }\end{array}$ & & & & \\
\hline
\end{tabular}


Table 3.1b Experimental conditions for the second set of experiments

\begin{tabular}{|l|c|c|c|c|}
\hline $\begin{array}{c}\text { Parameter } \\
\text { Investigated }\end{array}$ & Duration & Temperature & $\begin{array}{c}\text { Concentration } \\
\text { of } \mathrm{H}_{2} \mathrm{SO}_{4}(\mathrm{~A})\end{array}$ & $\begin{array}{c}\text { Concentration } \\
\text { of } \mathrm{H}_{2} \mathrm{SO}_{4}(\mathbf{B})\end{array}$ \\
$\begin{array}{l}\text { Experimental } \\
\text { Conditions }\end{array}$ & $0-48$ & 24 & 24 & 24 \\
\hline $\begin{array}{l}\text { Duration (hours)-2 } \\
\text { step }\end{array}$ & 30 & 30 & 30 & 30 \\
\hline Filter cake mass (g) & 1,12 & 1,12 & 1,12 & $0,28-1,12$ \\
\hline Acid to dust ratio & 558 & 558 & 558 & $186-558$ \\
\hline $\begin{array}{l}\mathrm{H}_{2} \mathrm{SO}_{4} \text { concentration } \\
(\mathrm{g} / \mathrm{l})-1^{\text {st }} \text { step }\end{array}$ & 152 & 152 & $124-279$ & $41-152$ \\
\hline $\begin{array}{l}\mathrm{H}_{2} \mathrm{SO}_{4} \text { concentration } \\
(\mathrm{g} / \mathrm{l})-2^{\text {nd }} \text { step }\end{array}$ & 160 & 160 & $60-210$ & 160 \\
\hline $\begin{array}{l}\text { Volume of water (ml) } \\
2^{\text {nd }} \text { step. }\end{array}$ & 98 & $25-98$ & 98 & 98 \\
\hline $\begin{array}{l}\text { Temperature }\left({ }^{\circ} \mathrm{C}\right) \\
2^{\text {nd }} \text { step }\end{array}$ & & & & \\
\hline
\end{tabular}




\section{Chapter 4}

\section{Results and discussion}

This chapter presents the results of the leaching experiments. It also discusses the further treatment required of the filtrate to produce a suitable feed for an electrolytic precipitation plant, waste streams produced and their required treatment, and the economic feasibility of zinc recovery from dust.

\subsection{RESULTS OF THE LEACHING EXPERIMENTS}

Results are graphically presented as the percentage extraction of metals in the dust against the value of a variable that was changed over a certain range. These ranges were determined by values in the literature (see Section 2.3.1 and Chapter 3) or by observations made during the execution of preliminary experiments. The exact values for these variables could not be determined from literature since there are no reported values for leaching conditions on bag house dusts. Percentage extraction was calculated from the concentrations of the metals present in the filtrate (produced after filtration of the leaching liquors) and concentrations reported in the bag house dust (Table 2.1).

The mass of the metals present in the filter cake (produced after primary treatment) used during leaching was calculated from Table 2.1 and the basis that $10 \%$ of the mass is lost through dissolution of water soluble compounds in primary treatment (Strobos and van $\mathrm{Zyl}$, 1997). The mass of the metals present in the filtrate was determined from the concentrations (analytically determined with the atomic absorption spectrophotometer) and the volume of filtrate produced (measured with a measuring cylinder). The percentage extraction is then the mass of a metal present in the filtrate divided by the mass of the relevant metal present in the filter cake used for leaching. All the experiments were performed in duplicate and the percentage extractions reported are the average of two identical experiments in each case. The results obtained during the duplication of experiments showed little deviation, as can be seen from the data presented in Appendices $\mathrm{A}$ and $\mathrm{B}$.

The graphs presenting percentage extraction are indications of the success of an experiment with regard to selectivity and extent of leaching taking place, but do not give absolute values that can be used to evaluate the feasibility of the extraction process. In order to produce zinc by means of electrolytic precipitation cells, a minimum concentration of zinc must be present in the process stream, used as feed to these cells. The concentrations of other elements must also be within permissible levels (see Section 2.3.3). Therefore, the actual concentrations of the metals and the volumes of filtrate produced are presented in tabular form as well. 
After the initial experiments were performed, no variation was seen in the zinc extraction efficiencies despite all the variations introduced during the second step of leaching. The experiments were then repeated with slightly different volumes of water utilised in the second step of leaching. Therefore, two sets of results are given for each variable that was investigated. In Appendices A and B the raw data for the two sets of experiments are reported.

Other than these reported results, visual observations were made that are now presented to further clarify the leaching experiments. Initially, when the concentrated sulphuric acid and water were mixed, the temperature of the mixture increased to approximately $100{ }^{\circ} \mathrm{C}$. Directly after mixing the water and acid, the mixture was added to the filter cake and then stirred manually for 20 minutes. The temperature increased even further during this leaching step due to the exothermic reaction. For the second leaching step, the reaction mixture was diluted further. After the second leaching step, the slurry was filtered with a Buchner filter.

\subsubsection{Duration of leaching}

Conditions for the experiments that were performed to evaluate the duration of leaching are described in Section 3.2.1.

In Figures $4.1 \mathrm{a}$ and $4.1 \mathrm{~b}$ the percentage extraction of zinc, aluminium, iron, magnesium and gallium are given. (In Figure $4.1 \mathrm{~b}$ the extraction efficiency of magnesium is not shown. Very high readings of magnesium in the filtrate were obtained, due to the high dilution that was required to operate in the working range of the atomic absorption spectrophotometer.)

The graphs in Figures 4.1a (first set of experiments) and 4.1b (second set of experiments) indicate that the effect of duration on extraction efficiency is basically irrelevant. This is an indication that most of the leaching occurs during the first leaching step. In Table 4.1 the concentrations for the various metals are given for 6 hours duration of leaching (for both the first and second set of experiments). However, the concentrations of these metals in the filtrate are approximately the same despite a further increase in the duration of leaching in the second step.

Observations from Table 4.1 include the large decrease in aluminium concentration (from $1677 \mathrm{mg} / \mathrm{l}$ to $333 \mathrm{mg} / \mathrm{l}$ ) and the high value reported for magnesium. Approximately one third of the mass of the filter cake is also lost (compare final mass of 18,3 to $30 \mathrm{~g}$ of filter cake originally). The low $\mathrm{pH}$ of 0,86 indicates that there is excess free acid present in the filtrate. (The mass of filter cake was not determined in the first set of experiments and the $\mathrm{pH}$ was not determined in the second set.) 


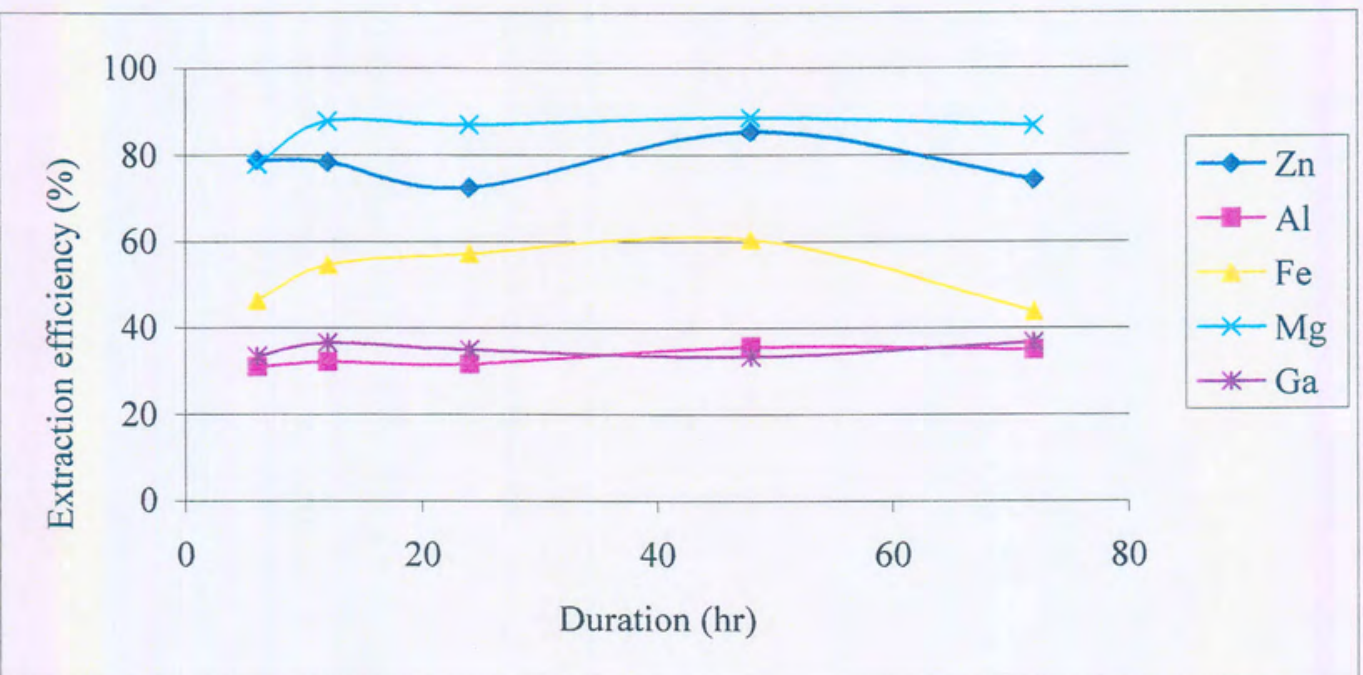

Figure 4.1a The effect of duration of leaching on extraction efficiency (first set of experiments).

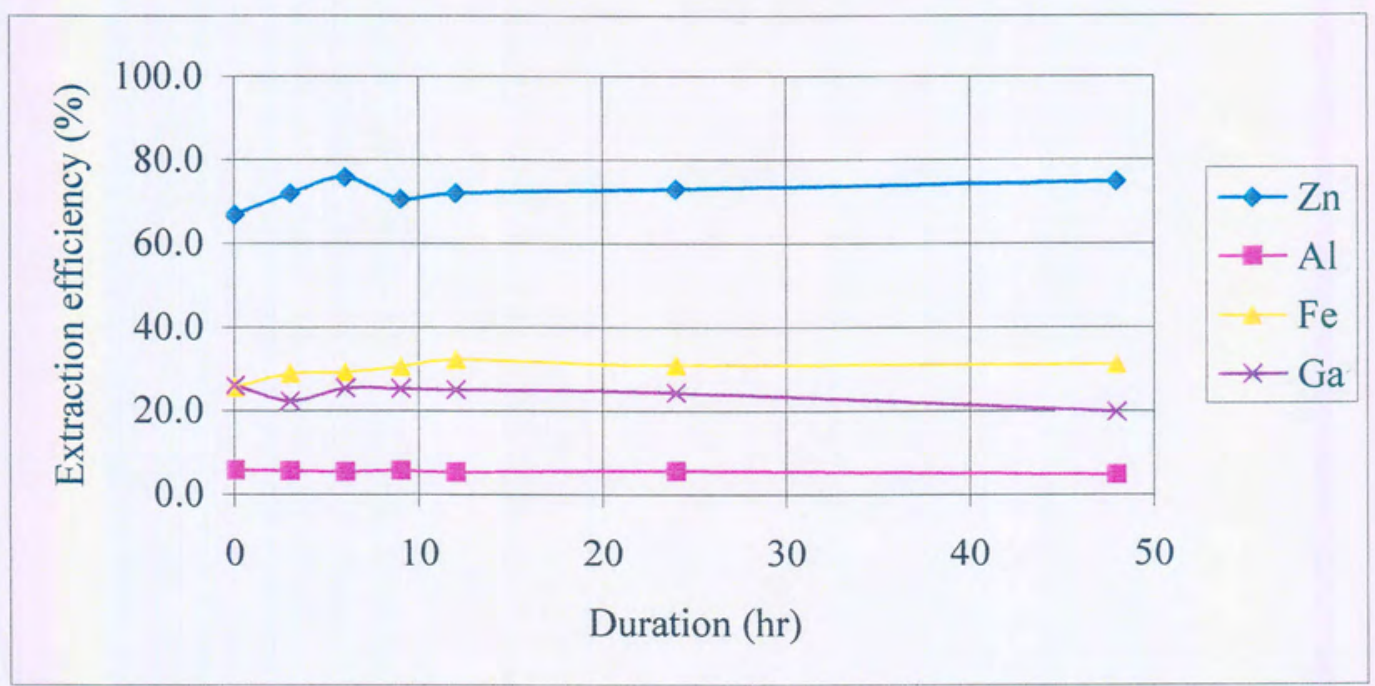

Figure 4.1b The effect of duration of leaching on extraction efficiency (second set of experiments). 
Table 4.1 Concentration of metals in the filtrate for 6 hours leaching in the second step, for the first and second set of experiments.

\begin{tabular}{|l|c|c|}
\hline \multicolumn{1}{|c|}{ Component } & $\begin{array}{c}\text { First set } \\
\text { concentrations } \\
\text { (mg/l) }\end{array}$ & $\begin{array}{c}\text { Second set } \\
\text { concentrations } \\
\text { (mg/l) }\end{array}$ \\
\hline Zinc & 7675 & $\mathbf{8 2 0 9}$ \\
\hline Magnesium & 11934 & 30420 \\
\hline Aluminium & 1677 & 333 \\
\hline Iron & 1259 & 1021 \\
\hline Gallium & 52 & 48 \\
\hline Volume (ml) & 260 & 213 \\
\hline $\begin{array}{l}\text { Mass of Filter } \\
\text { Cake }\end{array}$ & - & 18,3 \\
\hline pH & 0,86 & - \\
\hline
\end{tabular}

\subsubsection{Temperature of leaching}

In Figures $4.2 \mathrm{a}$ and $\mathrm{b}$ the effects of temperature on the extraction efficiency are presented. From the graph in Figure 4.2a a marked increase can be seen in the extraction efficiency for zinc, iron and magnesium, above $70{ }^{\circ} \mathrm{C}$. The results for these experiments compare well to those done for the duration of leaching, which were all performed at $98{ }^{\circ} \mathrm{C}$.

Increase in efficiencies during leaching in the second step is not very clear for the second set (Figure 4.2b). The extraction efficiencies for zinc is high in all these experiments and thus it can be concluded that in this case the first step of leaching resulted in a more complete dissolution of the zinc. It should be noted that during the first step of leaching a slightly more diluted acid concentration was used in the second set of experiments. More acid would thus have been available for leaching of these metals as compared to when iron and aluminium are leached out at considerable amounts. See discussion on the effect of the nature of the solvent in Section 4.3.

Tables $4.2 \mathrm{a}$ and $\mathrm{b}$ present the data from which the extraction efficiencies presented in Figure $4.2 \mathrm{a}$ and $\mathrm{b}$ have been calculated. The higher degrees of extraction at higher temperatures corresponds well with findings from Zeydabadi et al. (1997). 


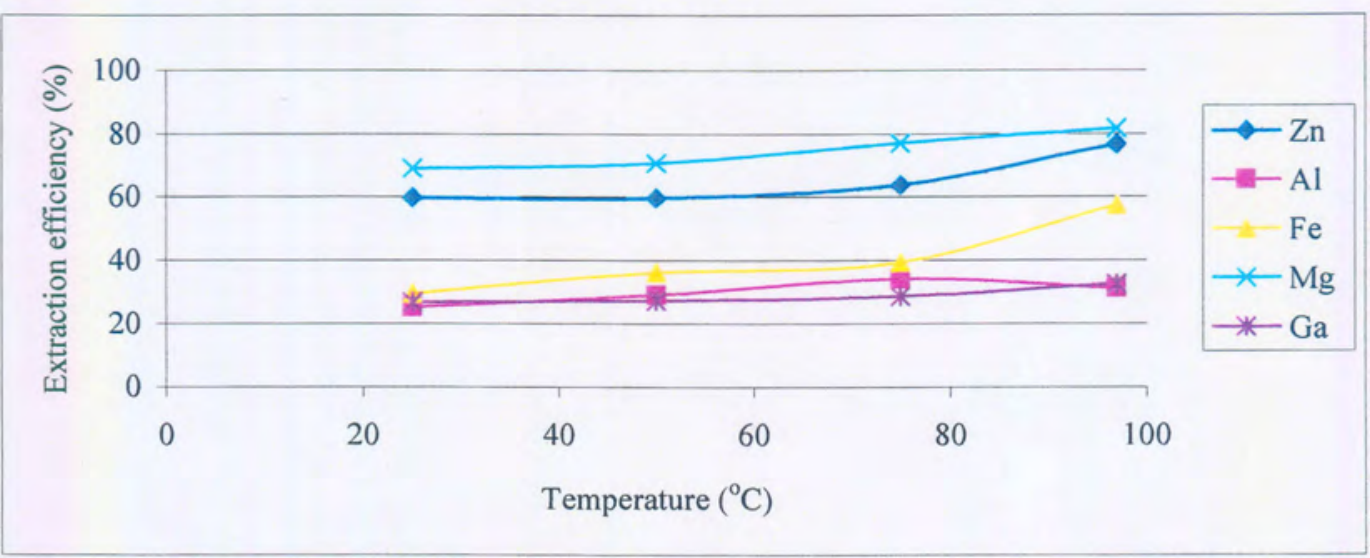

Figure 4.2a The effect of temperature of leaching on the extraction efficiency (first set of experiments).

Table 4.2a Concentrations in the filtrate of experiments on the influence of temperature.

\begin{tabular}{|l|c|c|c|c|}
\hline Temperature $\left(\mathbf{~}^{\mathbf{C}} \mathbf{C}\right)$ & $\mathbf{2 5}$ & $\mathbf{5 0}$ & $\mathbf{7 5}$ & $\mathbf{9 7}$ \\
\hline Zinc & 7907 & 7827 & 8468 & 6885 \\
\hline Aluminium & 1893 & 2222 & 2644 & 1615 \\
\hline Iron & 1155 & 1388 & 1414 & 1385 \\
\hline Magnesium & 15230 & 15505 & 15848 & 11693 \\
\hline Gallium & 57 & 59 & 62 & 50 \\
\hline Volume & 192 & 176 & 174 & 250 \\
\hline PH & 0,6 & 0,5 & 0,5 & 0,6 \\
\hline
\end{tabular}

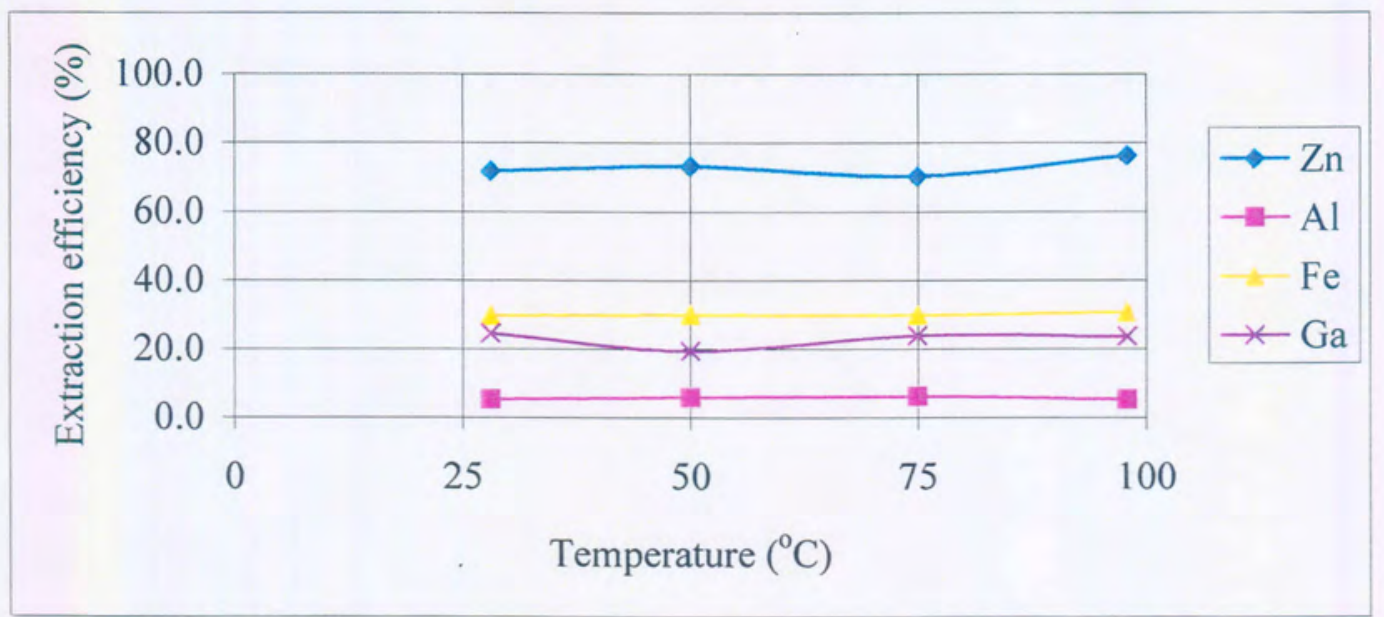

Figure 4.2b The effect of temperature of leaching on the extraction efficiencies (second set of experiments). 
Table 4.2b Concentrations in the filtrate of experiments on the influence of temperature.

\begin{tabular}{|l|c|c|c|c|}
\hline Temperature $\left.\mathbf{~}^{\mathbf{0}} \mathbf{C}\right)$ & $\mathbf{2 8}$ & $\mathbf{5 0}$ & $\mathbf{7 5}$ & $\mathbf{9 7}$ \\
\hline Zinc & 7257 & 7885 & 7703 & $\mathbf{8 0 2 7}$ \\
\hline Magnesium & 28079 & 28242 & 31237 & 31673 \\
\hline Aluminium & 330 & 383 & 419 & 351 \\
\hline Iron & 855 & $\mathbf{9 7 1}$ & 1145 & 1091 \\
\hline Gallium & 42 & 34 & 45 & 43 \\
\hline Volume (ml) & 229 & 218 & 205 & 222 \\
\hline Mass of filter cake (g) & 19,97 & 18,8 & 19 & 17 \\
\hline
\end{tabular}

\subsubsection{Concentration of sulphuric acid}

As described in Section 3.2.3, the effect of the concentration of sulphuric acid was evaluated by varying the amount of water added during the second leaching step and by varying the amount of acid added.

In Figures $4.3 \mathrm{a}$ and $4.3 \mathrm{~b}$ the extraction efficiencies obtained for variable amounts of water added in the second leaching step are presented. In Figure 4.3a less extraction efficiency is observed for all the metals analysed, except for aluminium at lower volumes of water added.

In Figure $4.3 \mathrm{~b}$ the same tendency was observed for all the metals where a higher extraction efficiency was observed with an increase in volume of water fed to the leaching reaction. This can be due to either of two reasons:

- better separation of dissolved substances due to less being present in the filtrate entrained in the filter cake, or

- inaccuracy of the atomic absorbtion spectro-photometer at high concentrations, giving lower readings than the actual readings.

It is not likely that a faster reaction rate, due to dilution factors in the second step, will have such a large influence on the process since from the previous results it seems that most of the leaching occurred in the first step of leaching. 


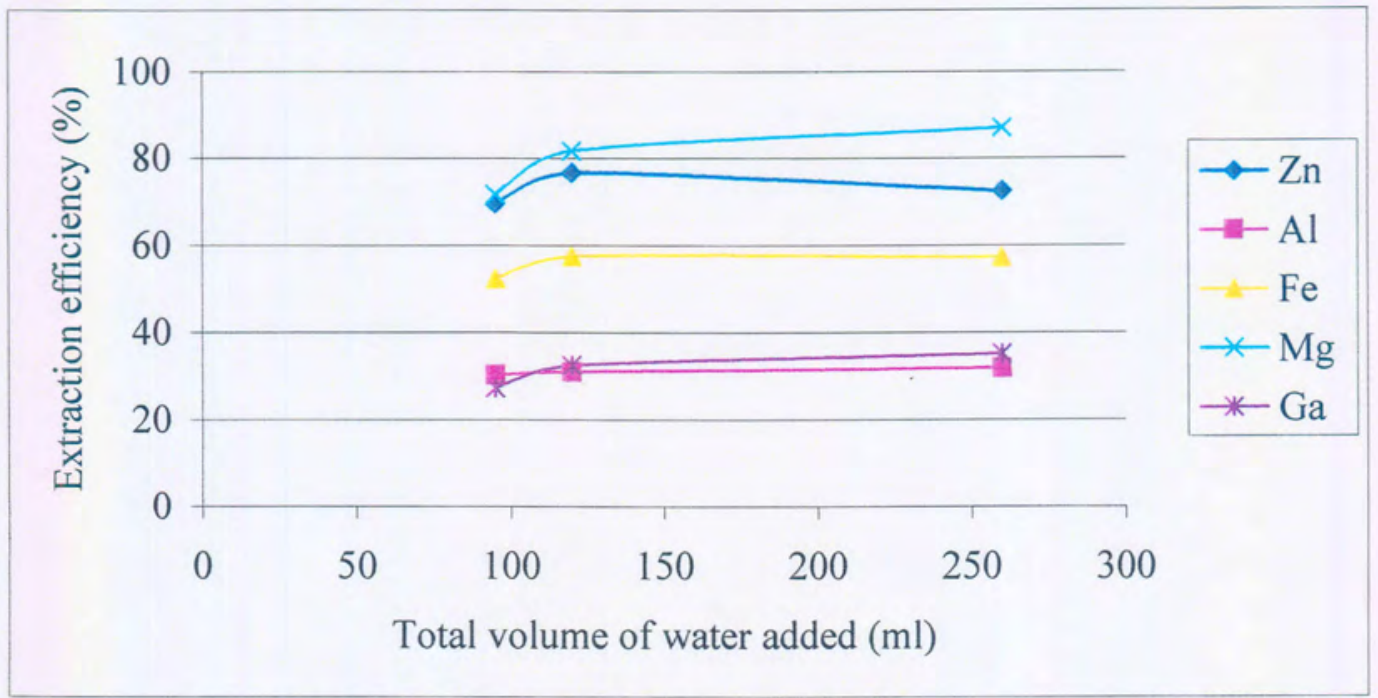

Figure 4.3a The effect of the volume of water added during leaching on the extraction efficiency (first set of experiments).

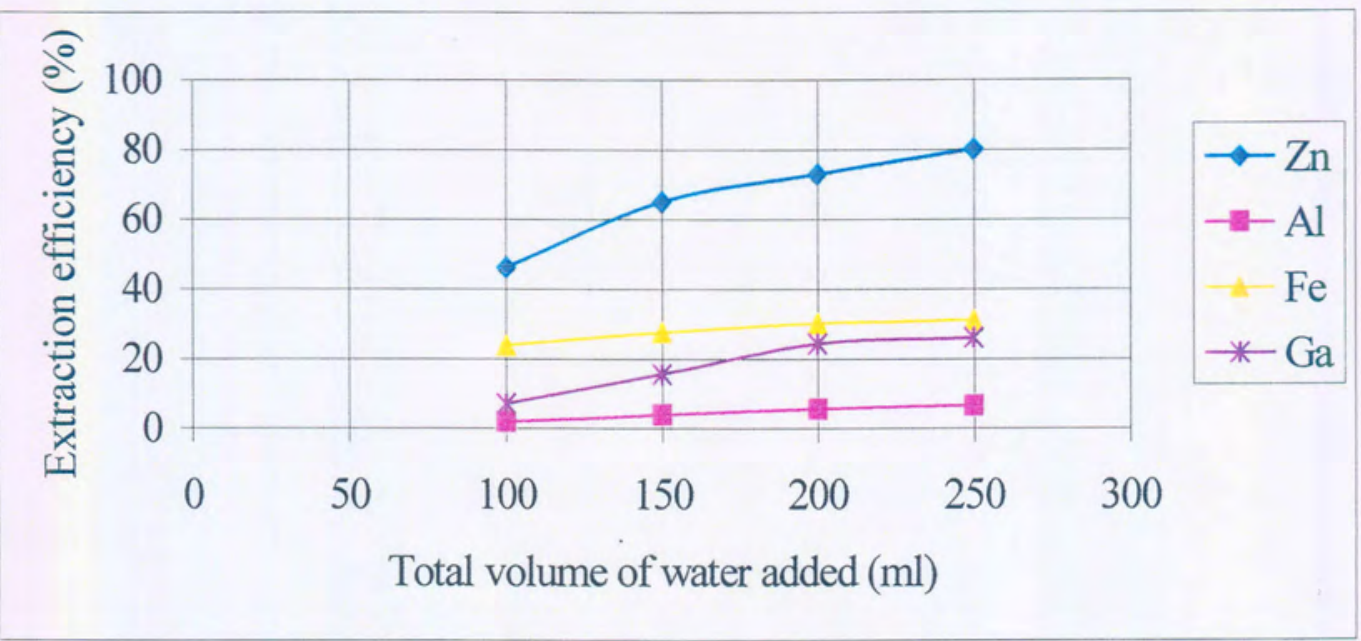

Figure 4.3b The effect of the volume of water added during leaching on the extraction efficiencies (second set of experiments).

In Table $4.3 \mathrm{~b}$ the concentrations for 100 and $200 \mathrm{ml}$ of water added is shown as well as the volume of filtrate produced in each case (second set of experiments). 
Table 4.3b Concentrations of metals in the filtrate of experiments performed with different volumes of water added.

\begin{tabular}{|l|c|c|}
\hline Volume of water $(\mathbf{m l})$ & $\mathbf{1 0 0}$ & $\mathbf{2 0 0}$ \\
\hline Zinc & 10878 & 8473 \\
\hline Magnesium & 42673 & 21528 \\
\hline Aluminium & 233 & 348 \\
\hline Iron & 1803 & 1108 \\
\hline Gallium & 25 & 46 \\
\hline Volume (filtrate) (ml) & 100 & 216 \\
\hline Mass of filter cake & & 18,56 \\
\hline
\end{tabular}

In Figures $4.3 \mathrm{c}$ and $4.3 \mathrm{~d}$ the percentage extraction for variations in the amount of acid added is presented. In Figure $4.3 \mathrm{c}$, the first data point (where $414 \mathrm{~g} / \mathrm{l}$ of acid was used), indicates that selective leaching for zinc and magnesium can be achieved.

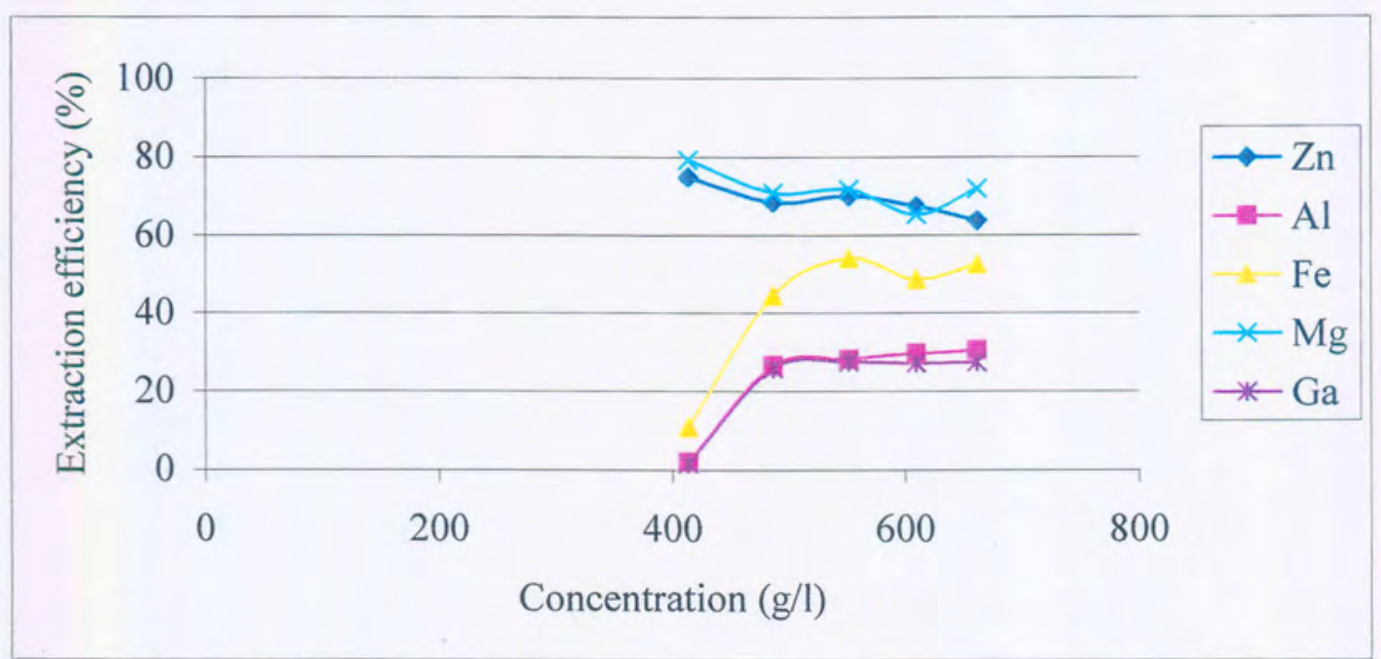

Figure 4.3c The effect of initial acid concentration (first step of leaching) on extraction efficiencies (first set of experiments).

Table $4.3 \mathrm{c}$ gives the concentrations of the metals in the filtrate for this data point. The $\mathrm{pH}$ is also reported as approximately 3,2 to 3,5 . This indicates that most of the free acid present was used in the reaction. The iron content was still relatively high (569 and 362 $\mathrm{mg} / \mathrm{l}$ ) and could still be detrimental to the extraction of zinc.

The results from the second set of experiments were more favourable than the first. In Figure $4.3 \mathrm{~d}$ it can be seen that at low concentrations of $190 \mathrm{mg} / \mathrm{l}$ almost no extraction of all the metals was achieved, except for magnesium that is not shown here. At $336 \mathrm{~g} / \mathrm{l}$ the percentage recovery for zinc was $71,2 \%$, aluminium $1,8 \%$ and iron $0,1 \%$. Therefore, for all the leaching experiments performed, this data point represents the most favourable conditions for leaching of zinc. 
Table 4.3c Concentrations of metals in the filtrate with an initial acid concentration of $414 \mathrm{~g} / \mathrm{l}$.

\begin{tabular}{|l|c|c|}
\hline Component & $\begin{array}{c}\text { Concentration } \\
(\mathbf{m g} / \mathbf{l})\end{array}$ & $\begin{array}{c}\text { Concentration } \\
(\mathbf{m g} / \mathbf{l})\end{array}$ \\
\hline Zinc & 12015 & 11000 \\
\hline Aluminium & 277 & 84 \\
\hline Iron & 569 & 362 \\
\hline Magnesium & 21995 & 17222 \\
\hline Gallium & 4 & 4 \\
\hline Volume (m) & 150 & 176 \\
\hline PH & 3,19 & 3,45 \\
\hline
\end{tabular}

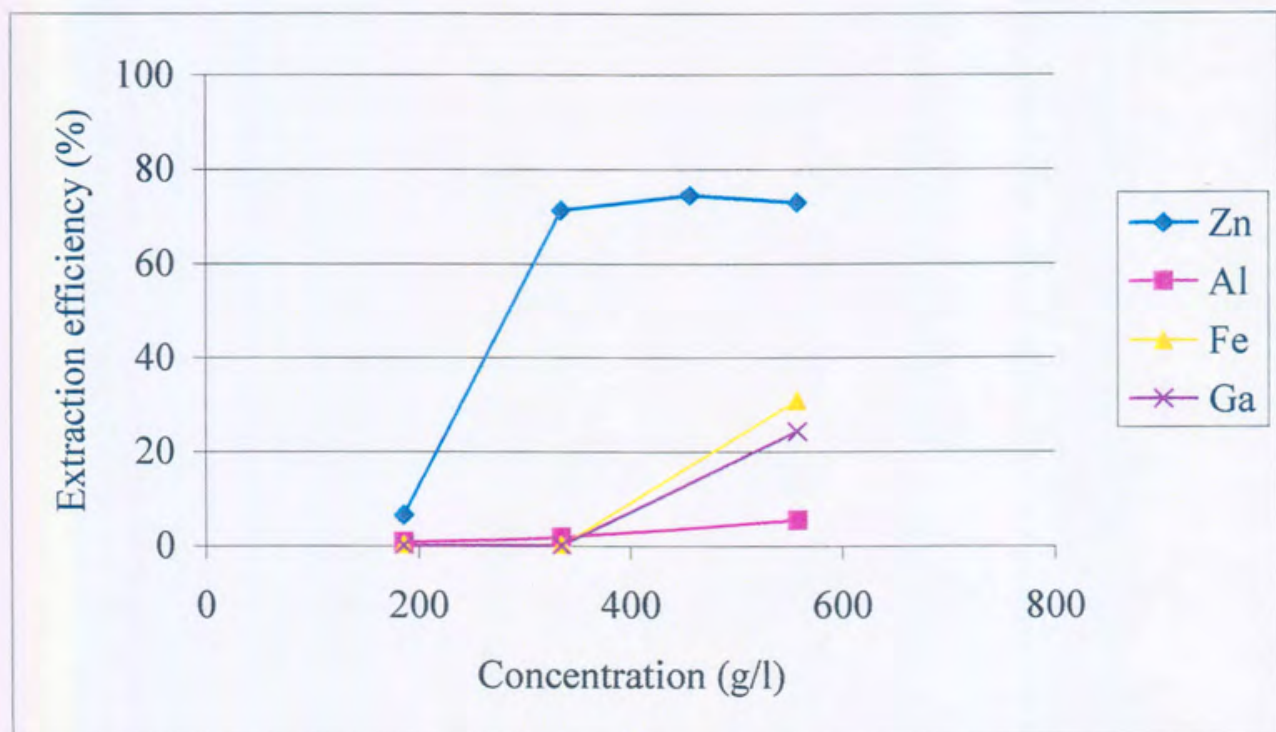

Figure 4.3d The effect of initial acid concentration (first step of leaching) on extraction efficiencies (second set of experiments).

In Table $4.3 \mathrm{~d}$ the concentrations of all the metals that was used to calculate the percentage extractions presented in Figure $4.3 \mathrm{~d}$ are given. At sulphuric acid concentration of $336 \mathrm{~g} / \mathrm{l}$, the zinc concentration is $9628 \mathrm{mg} / \mathrm{l}$ and that for iron below the range where the atomic absorption photometer could detect it, but this is close to zero $\mathrm{mg} / \mathrm{l}$. For this experiment it can be seen that $184 \mathrm{ml}$ of filtrate was produced for $30 \mathrm{~g}$ filter cake leached.

After evaluation of the influence of concentration of acid on the extraction efficiency, variations between the first and second set of experiments can be addressed. A comparison between Figures $4.1 \mathrm{a}$ and $4.1 \mathrm{~b}$ shows that a greater percentage extraction of zinc, aluminium and iron was achieved in the first set of experiments, although the increase in extraction are greater for aluminium and iron than for zinc. Therefore, it can be seen that at these conditions there is a tendency to selectively leach zinc rather than aluminium and iron. 
Table 4.3d Concentrations of metals in the filtrate with various initial acid concentrations.

\begin{tabular}{|l|c|c|c|c|}
\hline Initial concentration (g/l) & $\mathbf{1 8 6}$ & $\mathbf{3 3 6}$ & $\mathbf{4 5 8}$ & $\mathbf{5 5 8}$ \\
\hline Zinc & 953 & 9628 & $\mathbf{8 6 9 6}$ & $\mathbf{8 4 7 3}$ \\
\hline Magnesium & 23724 & 25272 & & 21528 \\
\hline Aluminium & 55 & 147 & & 348 \\
\hline Iron & $<100$ & $<100$ & & 1108 \\
\hline Gallium & 0,3 & 5,5 & & 46 \\
\hline Volume & 196 & 184 & 211 & 216 \\
\hline
\end{tabular}

The reason for the increased selectivity of leaching in the second set of leaching experiments can be explained by the concentration of acid used in the first step. In the first set of experiments $30 \mathrm{ml}$ of water were used and in the second set $40 \mathrm{ml}$ of water with $20 \mathrm{ml} 91 \%$ acid. This resulted in acid concentrations of 660 and $570 \mathrm{~g} / 1$ respectively. Utilising a less concentrated acid led to increased selectivity for zinc, as also found by Zeydabadi et al. (1997).

In the following section the further processing of a process stream, such as that produced under these leaching conditions ( $336 \mathrm{~g} / \mathrm{l}$ of acid in the first leaching step), to produce a suitable solution for electrolytic precipitation of zinc, will be addressed.

\subsection{PRODUCTION OF A SOLUTION SUITABLE FOR ELECTROLYTIC PRECIPITATION}

The aim of leaching is to produce a zinc sulphate solution that is suitable for further treatment in electrolytic precipitation cells. The characteristics of such a zinc sulphate stream is:

- a zinc concentration of 50 to $150 \mathrm{~g} / 1$ and

- minimal concentrations for other constituents, as discussed in Section 2.3.3.

When evaluating the results of the leaching experiments to these criteria, certain conclusions can be made. The concentration of sulphuric acid and the acid to dust ratio in the first step of leaching is critical to minimise the concentration of other elements in the filtrate. From the experiments performed the best results were obtained with $336 \mathrm{~g} / \mathrm{l}$ and an acid to dust ratio of 0,56 . This is, however, much higher than the theoretical value of approximately 0,2 required to leach for zinc

The amount of zinc present in the filtrate was $9628 \mathrm{mg} / \mathrm{l}$. This could vary with the amount of water used for dilution in the second step. The influence of the second step of leaching seems insignificant. Further experiments to clarify the second step of leaching and to optimize the selection of zinc in the first step of leaching have to be performed. Selectivity has to be optimised since aluminium is present in the filtrate at values of 145 $\mathrm{mg} / \mathrm{l}$. If present in the electrolyte solution it causes an increase in the electrolyte 
resistivity, which in turn will cause a higher power requirement. Magnesium is present in values higher than $20000 \mathrm{mg} / \mathrm{l}$. This could also lead to increased electrolyte resistivity.

To address the low zinc concentration of the dust and to a reasonable extent the presence of other constituents in the dust, the processes of solvent extraction followed by stripping is discussed here. If we consider the solvent extraction in Figure 2.2, streams into this unit would be the filtrate produced after leaching and the D2EHPA in n-heptane (organic) stream. This solvent extraction process would consist of mixing tanks, followed by a phase separation stage. Streams leaving the process would be an organic stream, containing zinc as well as other metals that were extracted with zinc and an aqueous stream depleted of zinc. Besides the zinc, other elements such as trivalent iron will also be in the organic phase (see Figure 2.5, (McKetta 1984)). Virtually all the magnesium will, however, still be in the aqueous phase. This stream can be reused for leaching if it is treated in order to remove metals and sulphates. The treatment of polluted streams generated during treatment of baghouse dust and the disposal of solid waste will be discussed in Section 4.3.

After the solvent extraction stage follows the stripping stage. The feed streams to this stage are the organic phase (now loaded with zinc as well as other elements such as iron) and a sulphuric acid rich stream produced after leaching. In order to ensure the feed stream to the electrolytic precipitation cells have a zinc concentration of 50 to $150 \mathrm{~g} / \mathrm{l}$, an organic to strip acid ratio of approximately 10:1 has to be used (McKetta 1984). This would results in a zinc concentration of approximately $100 \mathrm{~g} / \mathrm{l}$.

\subsection{WASTE STREAMS PRODUCED AND POSSIBLE TREATMENT}

If a treatment strategy for baghouse dust (as proposed in this dissertation) will be implemented, a number of waste streams will result. The most environmentally responsible approach would be to design the treatment process for zero liquid discharge. Therefore, no water would be consumed by the plant, except that which would be lost through co-disposal with sludge and evaporation.

During primary treatment, a stream of water will result that will contain all the soluble compounds in the dust. This will include chromate and sulphate associated with sodium, potassium and calcium. However, the chromate will then be addressed through reduction and precipitation as a hydroxide, as discussed in Section 2.2. The water produced after primary treatment could be reused as make-up water. However, a built up of salts to the saturation level will result and thus some water will have to be removed from the circuit. This water will be unfit for discharge into public streams and will have to be treated prior to reuse or discharge.

Since it will contain mono-valent ions (sodium and potassium), feasible treatment options could be membrane treatment such as reverse osmosis (Mallevialle et al., 1996) or ion exchange. The resultant brine from the above processes will also have to be treated further through, for example, evaporation. 
The solid residue (filter cake) produced after primary treatment is relatively safe to dispose. However, it does contain heavy metals such as zinc that could have a negative impact on ground water if it is leached out. This is a further motivation to recover the zinc from the baghouse dust. During the recovery process of zinc from baghouse dust, a magnesium sulphate rich stream will be produced. In order to maintain the policy of zero discharge, this stream will have to be treated and then reused.

One possibility would be to remove metals from the solution by precipitating it as hydroxide if the $\mathrm{pH}$ is raised. Magnesium will only precipitate at a $\mathrm{pH}$ of approximately 10,5 (Weast $\mathrm{RC} ; 1971$ ). To raise the $\mathrm{pH}$ to this value, sodium or calcium hydroxide can be used. If sodium hydroxide is used the advantage would be that the sodium sulphate will not co-precipitate with magnesium hydroxide. Pure magnesium hydroxide can be used as a neutralisation agent in water treatment, but could also have an application in the pharmaceutical industry (Kirk Othmer, 1996). The latter grade of magnesium hydroxide has a high monetary value of $\mathrm{R} 20$ to $\mathrm{R} 30 / \mathrm{kg}$ (Crest Chemicals, 2001). If calcium hydroxide is used to raise the $\mathrm{pH}$, some calcium sulphate will precipitate with the magnesium hydroxide. Calcium sulphate precipitates slowly, but given enough time and surface area, it will precipitate to the saturation level of approximately $1350 \mathrm{mg} / \mathrm{l}$ sulphate in the absence of highly soluble ions, such as sodium and magnesium (Weast RC, 1971).

\subsection{ECONOMIC FEASIBILITY OF ZINC RECOVERY FROM BAGHOUSE DUST}

Prior to addressing the costs of treatment associated with the proposed treatment strategies in this dissertation, the cost for disposal of a similar baghouse dust at Holfontein hazardous waste disposal site is presented. This cost will be on the basis of the dust being in the form of a sludge containing $25 \%$ moisture (mixing with water is required to prevent inhalation of small particles). The cost for transport to Holfontein is R 177,00/t and for disposal R 312,00/t (Waste Tech, 2001). Unit cost, purity and utilization efficiency for the different chemicals used for treatment of the dust at Holfontein are given in Table 4.4 (Crest Chemicals, 2001).

Table 4.4 Unit costs, purity and utilization efficiency for chemicals as used in the calculations of cost (Crest Chemicals, 2001).

\begin{tabular}{|l|c|c|c|}
\hline Chemical & Cost (R/t) & Purity (\%) & $\begin{array}{c}\text { Utilisation } \\
\text { efficiency (\%) }\end{array}$ \\
\hline Ferrous sulphate & 2480,00 & 100 & 100 \\
\hline Lime & 550,00 & 90 & 60 \\
\hline Sulphuric acid & 90,00 & 98 & - \\
\hline
\end{tabular}

In order to reduce the chromium in the baghouse dust to a hydroxide form, it is treated with ferrous sulphate and lime prior to disposal according to the following reactions (Section 2.2): 


$$
\begin{array}{lll}
3 \mathrm{Fe}^{2+}+\mathrm{CrO}_{4}^{2-}+4 \mathrm{H}_{2} \mathrm{O} & \Leftrightarrow & 3 \mathrm{Fe}^{3+}+\mathrm{Cr}^{3+}+8 \mathrm{OH}^{-} \\
\mathrm{Cr}^{3+}+3 \mathrm{H}_{2} \mathrm{O} & \Leftrightarrow & \mathrm{Cr}(\mathrm{OH})_{3}+3 \mathrm{H}^{+} \\
\mathrm{Fe}^{3+}+3 \mathrm{H}_{2} \mathrm{O} & \Leftrightarrow & \mathrm{Fe}(\mathrm{OH})_{3}+3 \mathrm{H}^{+}
\end{array}
$$

The costs associated with transport, treatment and disposal of the baghouse dust is calculated as follows:

Mass of solids for transport

$$
\begin{aligned}
& =3600 \times 1,25 \\
& =4500 \mathrm{~kg} / \text { day }
\end{aligned}
$$

The transport cost per day

$$
\begin{aligned}
& =4500 / 1000 \times \mathrm{R} 177,00 \\
& =\mathrm{R} 796,50
\end{aligned}
$$

Amount of chromium to be treated (Table 2.1)

$$
\begin{aligned}
& =(3,18 / 100) \times 3600 \mathrm{~kg} / \text { day } \\
& =114,5 \mathrm{~kg} / \text { day }
\end{aligned}
$$

Amount of ferrous sulphate $(\mathrm{FeSO} 4 \cdot 7 \mathrm{H} 2 \mathrm{O})$

$=($ mass of chromium/molar mass of chromium $) \times$ molar mass of ferrous sulphate $\mathrm{x}$ molar ratio

$$
\begin{aligned}
& =(114,5 / 52) \times 3 \times(277,8) \\
& =1835 \mathrm{~kg} / \text { day }
\end{aligned}
$$

Amount of lime required $(\mathrm{CaO})$

$=($ moles of chromium + moles of iron $) \times$ molar ratio $x$ molar mass of lime/(purity $x$ utilization efficiency)

$$
\begin{aligned}
& =(((114,5 / 52)+(1835 / 277,8)) \times(3 / 2) \times 56)) /(0,6 \times 0,9) \\
& =1370 \mathrm{~kg} / \text { day }
\end{aligned}
$$

Amount of sludge formed

= equivalent amount of ferric hydroxide + equivalent amount of chromium hydroxide + equivalent amount of gypsym to lime added

$=((1835 / 277,8) \times 107)+((114,5 / 52) \times 103)+((1370 / 56) \times 172)$

$=5141 \mathrm{~kg}$

Mass of solids for disposal including 25\% moisture

$=($ dust - chromium + sludge) $\times 1,25$ (moisture)

$=(3600-114,5+5141) \times 1,25$

$=10783 \mathrm{~kg} / \mathrm{day}$

The cost for treatment per day

$=$ cost of ferrous sulphate + lime 


$$
\begin{aligned}
& =(\mathrm{R} 2480,00 \times 1835) / 1000+(\mathrm{R} 550,00 \times 1370) / 1000 \\
& =\mathrm{R} 5304,30 / \text { day }
\end{aligned}
$$

The disposal cost per day

$$
\begin{aligned}
& =10783 / 1000 \times \text { R } 312,00 \\
& =\text { R } 3364,30 / \text { day }
\end{aligned}
$$

The total cost for disposal at Holfontein

$=(\mathrm{R} 796,50+\mathrm{R} 5304,30+\mathrm{R} 3365,30)$

$=\mathrm{R} 9466,10 /$ day based on $3600 \mathrm{~kg} /$ day production of baghouse dust.

The cost for disposal at Holfontein is therefore

$=\mathrm{R} 3455126,50$ per annum (based on a 7 day week and production of $3600 \mathrm{~kg}$ baghouse dust/day).

In contrast to disposal at Holfontein, the dust can be treated through primary treatment and leached with sulphuric acid to recover zinc. An economic evaluation of the proposed process can be subdivided into two sections, namely capital costs and operational costs. For the purpose of this evaluation of the process, only the operational costs, and more in particular the major chemical costs, will be evaluated.

The costs for this option can be split into three sections: primary treatment cost, revenue from zinc recovery and chemical costs for leaching and treatment of the waste stream with lime. For costing purposes the price for zinc is taken as $\$ 815,00 /$ ton at an exchange rate of $R$ 8,55/ \$ (Business Report, 2001).

For primary treatment the chemical treatment cost is the same as for disposal at Holfontein, namely R 5 304,30/day.

The amount of sludge to be transported and disposed, including $25 \%$ moisture

$$
\begin{aligned}
& =5141 \times 1,25 \\
& =6426 \mathrm{~kg} / \text { day }
\end{aligned}
$$

The cost for transport and disposal of this sludge

$$
\begin{aligned}
& =(\mathrm{R} 177,00+\mathrm{R} 312,00) \times 6426 / 1000 \\
& =\mathrm{R} 3142,30 / \text { day }
\end{aligned}
$$

The revenue from zinc recovery can be calculated as follows:

The amount of zinc leached out from experimental results (See Table 4.3d)

$=$ concentration of zinc $\mathrm{x}$ volume of filtrate $\mathrm{x}$ scale factor

$=9,628 \mathrm{~g} / \mathrm{l} \times 0,184 \mathrm{l} \times 3600 / 0,03$

$=212,7 \mathrm{~kg} /$ day

The revenue associated with this zinc

$$
=212,7 \mathrm{~kg} / 1000 \times \$ 815,00 \times \mathrm{R} 8,55 / \$
$$


$=\mathrm{R} 1482,20 /$ day

The cost associated with sulphuric acid and lime is as follows:

The amount of sulphuric acid required for leaching

$=$ acid to dust ratio $\mathrm{x}$ the amount of dust treated per day $\mathrm{x}$ recovery after primary treatment / purity (Note that approximately $10 \%$ of the mass of the dust is lost through dissolution during primary treatment.)

$=(0,56 \times 3600 \times 0,9) / 0,98=1851 \mathrm{~kg}$

Assume that an equivalent amount of lime is added for neutralisation than the amount of acid added

$=$ mass of sulphuric acid added $\mathrm{x}$ purity $\mathrm{x}$ molar mass of $\mathrm{CaO} /$ molar mass of sulphuric acid /(purity $\mathrm{x}$ utilization efficiency)

$=(1851 \times 0,98 \times 56 / 98) /(0,9 \times 0,6)$

$=1919 \mathrm{~kg} /$ day

The cost for sulphuric acid

$=\mathrm{R} 90,00 /$ ton $\times 1851 / 1000$

$=\mathrm{R} 166,60 /$ day

The cost for lime

$=\mathrm{R} 550,00 \times 1919 / 1000$

$=\mathrm{R} 1055,50 /$ day

The total cost for this treatment option is therefore

$=\mathrm{R} 5304,30+\mathrm{R} 3142,30+\mathrm{R} 166,60+\mathrm{R} 1055,50-\mathrm{R} 1482,20$

$=\mathrm{R} 8$ 186,50/day

The cost is therefore R 2988072,50 per annum. However, compared to disposal at a site such as Holfontein, approximately R 467054,00 per annum (based on a 7 day week and 3 $600 \mathrm{~kg}$ dust produced per day) can be saved.

This treatment cost can possibly be further reduced, by either utilising the magnesium hydroxide produced during the treatment process in the water treatment industry or, using it in the pharmaceutical industry. The selective leaching for magnesium, as the results presented in Section 4.1 indicated, could therefore be a more viable option.

A further option would be to extract the gallium present in the dust. This has a much higher monetary value than the other metals in the dust. However, it was not leached out very effectively with sulphuric acid. 


\section{Chapter 5}

\section{Conclusions and Recommendations}

From the leaching experiments performed it was concluded that zinc could effectively be leached from baghouse dust, with regard to iron and aluminium, using sulphuric acid. These findings were similar to those of Zeydabadi et al. (1997). However, it is not possible to selectively leach for zinc with respect to magnesium, but the opposite is possible.

Optimal extraction was obtained using a sulphuric acid concentration of $336 \mathrm{~g} / \mathrm{l}$ and an acid to dust ratio of 0,56 . These were the conditions for the first step of leaching with a duration of approximately 20 minutes. The percentage recovery for zinc was $71,2 \%$, alluminium $1,8 \%$ and iron $0,1 \%$. The influence of the second leaching step on the percentage extraction of the various compounds was insignificant. Even despite all the variations of conditions in the second step of leaching, the extraction efficiencies were similar. It is recommended that further experiments be performed to optimise the first leaching step.

According to McKetta (1984), it would be possible to produce a zinc sulphate solution suitable for electrolytic precipitation, from the filtrate produced after leaching, through solvent extraction. Zinc produced through electrolytic precipitation could be sold at approximately $\$ 815 / \mathrm{t}$ (Business Report, 2001). Due to the high chemical cost associated with the leaching and treatment of waste streams produced, it is not economically feasible to extract zinc from baghouse dust when addressed in isolation. However, should these costs be compared with the cost associated with disposing of the baghouse dust at a registered waste disposal site, this method for treatment will be viable. The cost for treatment and disposal of the dust at Holfontein has been calculated and amounts to R 3 455126,50 per annum. The cost with zinc recovery amounts to $R 2988072,50$ per annum and therefore a saving of R 467054,00 per annum (based on a 7 day week and 3 $600 \mathrm{~kg}$ dust produced per day).

Another option could be if magnesium hydroxide of pharmaceutical grade (R20-30/kg) could be precipitated. The leaching experiments indicated that in the event of magnesium hydroxide production, it is possible to selectively leach for magnesium. This was achieved most effectively at a sulphuric acid concentration of $186 \mathrm{~g} / \mathrm{l}$ and an acid to dust ratio of 0,26 .

Finally, the possibility of extracting other elements, both upstream and downstream of the leaching step in the prescribed process, should be investigated. These may include, for example, gallium (for use in the superconductor industry) and potassium (for use in the fertilizer industry). 
However, in the case of gallium, other leaching mediums (such as hydrochloric acid; Ulman, 1997) should be investigated as the present results based on sulphuric acid were not successful. 


\section{References}

AMER S, FIGUEIREDO J.M. and LUIS A (1995) The recovery of zinc from the leach liquors of the CENIM-LNETI process by solvent extraction with di (2-ethylhexyl) phosphoric acid Hydrometallurgy, 37 (2), 323-337.

BEUKES J.P, PIENAAR J.J and LACHMAN G and GIESEKKE E.W (1999) The reduction of hexavalent chromium by sulphite in wastewater Water $S A 25$ (2) 363-370.

Business Report (2001) Pretoria News, Independent Newspaper Company, 20 September, 2001.

COULSON J.M and RICHARDSON J.F (1996) Chemical Engineering, Butterworth Heineman, Oxford, Vol. 2, 287.

Crest Chemicals (2001) Telephone communication, September 2001.

EVANS J.W and DE JONGHE L.C (1991) The production of inorganic materials, McMillan Publishing Company, New York, 301-305.

GILCHRIST J.D, (1989) Extraction Metallurgy Third Edition, Pergamon Press, Oxford, 290.

GILL, C.B (1980) Nonferrous Extractive Metallurgy, John Wiley and Sons, New York, 265-266.

KLOCKER H, MARR R and MULLER H, (1997) Mass transfer based on Chemical Potential Theory: $\mathrm{ZnSO}_{4} / \mathrm{H}_{2} \mathrm{SO}_{4} / \mathrm{D} 2 \mathrm{EHPA}$ American Institute of Chemical Engineers Journal, 43 (10), 2479-2487.

KIRK-OTHMER, (1993) Encyclopedia of chemical technology, Fourth Edition, John Wiley \& Sons, New York, 6, 228-263.

KIRK-OTHMER, (1996) Encyclopedia of chemical technology, Fourth Edition, John Wiley \& Sons, New York, 24, 817.

KIRK-OTHMER, (1997) Encyclopedia of chemical technology, Fourth Edition, John Wiley \& Sons, New York, 21, 1016.

LANGMORE K (1998) Minimum requirements for the handling, classification and disposal of hazardous waste, The waste management series, $2^{\text {nd }}$ edition, Department of water affairs and forestry. 
MALLEVIALE J, ODENDALL P E and WIESNER M R (1996) Water treatment membrane processes, McGraw-Hill, New York, 9-8.

MCKETTA J.J, (1984) Encyclopedia of chemical processing and design, Marcell and Dekker Inc, New York, 21 , 57.

NRIAGU O and NIEBOER E, (1989) Chromium in the Natural \& Human Environments, John Wiley \& Sons, 434.

OMORI Y, (1987) Blast furnace phenomina and modelling, Elsevier applied science publishing, New york, 545-567.

RITCEY G.M and ASHBROOK A.W, (1979) Process Metallurgy 1; Solvent Extraction: Principles and applications to process metallurgy; Part 2 Elsevier Scientific Publishing Company, Amsterdam, 534.

ROSENQVIST, T (1983) Principles of extractive Metallurgy 2nd Edition, McGraw Hill, 444.

STEGEMAN J A, ROY A, CALDWELL R J, SCHILLING P J AND TITTSWORTH R (2000) Understanding environmental leachability of electric arc furnace dust, Journal of environmental engineering, February, 112-120.

STROBOS JG and VAN ZYL CA (1997) Treatment of baghouse dust from ferrochrome foundries Project Report, University of Pretoria, 1-20.

ULMAN F, GERHARTZ W and ELVERS B(1988) Ullmann's encyclopedia of industrial chemistry, $5^{\text {th }}$ edition, B3: Unit operations 2, 6-45.

Waste Tech (2001) Telephone and facsimile communication, September 2001.

WEAST R C (1971) CRC Handbook of chemistry and physics $52^{\text {nd }}$ Edition, The Chemical rubber CO, Cleveland, D107 and B79.

ZEYDABADI B, MOWLA D, SHARIAT MH and KALAJAHI J (1997) Zinc recovery from blast furnace flue dust Hydrometallurgy, 47, 113-125. 


\section{Appendix A}

\section{Raw data for the first set of experiments} (Volumes of water in first and second step (typically): 30 and 200 or $100 \mathrm{ml}$ )

Table A.1 Conditions for the first set of experiments.

\begin{tabular}{|c|c|c|c|c|}
\hline Number & $\begin{array}{c}\text { Temperature } \\
\left({ }^{\circ} \mathrm{C}\right)\end{array}$ & $\begin{array}{l}\text { Duration } \\
\text { (hr) }\end{array}$ & $\begin{array}{c}\text { Volume acid added } \\
(\mathrm{ml})\end{array}$ & $\begin{array}{c}\text { Volume water added } \\
(\mathrm{ml})\end{array}$ \\
\hline $1 \mathrm{~A}$ & 97 & 6 & 20 & 230 \\
\hline $1 \mathrm{~B}$ & 97 & 6 & 20 & 230 \\
\hline $2 \mathrm{~A}$ & 97 & 12 & 20 & 230 \\
\hline $2 B$ & 97 & 12 & 20 & 230 \\
\hline $3 \mathrm{~A}$ & 97 & 24 & 20 & 230 \\
\hline $3 \mathrm{~B}$ & 97 & 24 & 20 & 230 \\
\hline $4 \mathrm{~A}$ & 97 & 48 & 20 & 230 \\
\hline $4 B$ & 97 & 48 & 20 & 230 \\
\hline $5 \mathrm{~A}$ & 97 & 72 & 20 & 230 \\
\hline $5 B$ & 97 & 72 & 20 & 230 \\
\hline $6 \mathrm{~A}$ & 25 & 24 & 20 & 130 \\
\hline $6 \mathrm{~B}$ & 25 & 24 & 20 & 130 \\
\hline $7 \mathrm{~A}$ & 50 & 24 & 20 & 130 \\
\hline $7 B$ & 50 & 24 & 20 & 130 \\
\hline $8 \mathrm{~A}$ & 75 & 24 & 20 & 130 \\
\hline $8 B$ & 75 & 24 & 20 & 130 \\
\hline $9 \mathrm{~A}$ & 97 & 24 & 10 & 130 \\
\hline 9B & 97 & 24 & 10 & 130 \\
\hline $10 \mathrm{~A}$ & 97 & 24 & 12,5 & 130 \\
\hline $10 \mathrm{~B}$ & 97 & 24 & 12,5 & 130 \\
\hline $11 \mathrm{~A}$ & 97 & 24 & 17,5 & 130 \\
\hline $12 \mathrm{~B}$ & 97 & 24 & 17,5 & 130 \\
\hline $12 \mathrm{~A}$ & 97 & 24 & 20 & 230 \\
\hline $12 \mathrm{~B}$ & 97 & 24 & 20 & 230 \\
\hline $13 \mathrm{~A}$ & 97 & 24 & 20 & 105 \\
\hline 13B & 97 & 24 & 20 & 105 \\
\hline $14 \mathrm{~A}$ & 97 & 24 & 20 & 130 \\
\hline $14 \mathrm{~B}$ & 97 & 24 & 20 & 130 \\
\hline $15 \mathrm{~A}$ & 97 & 24 & 20 & 105 \\
\hline $15 \mathrm{~B}$ & 97 & 24 & 20 & 105 \\
\hline $16 \mathrm{~A}$ & 97 & 24 & 20 & 130 \\
\hline $16 \mathrm{~B}$ & 97 & 24 & 20 & 130 \\
\hline
\end{tabular}


Table A.2 Concentrations of metals in filtrate after leaching (mg/l)*.

\begin{tabular}{|c|c|c|c|c|c|c|c|}
\hline Number & $\mathrm{PH}$ & $\begin{array}{c}\text { Volume } \\
(\mathrm{ml})\end{array}$ & Zinc & Alluminium & Iron & Magnesium & Gallium \\
\hline $1 \mathrm{~A}$ & $0,86 \mid$ & 260 & 7675 & 1677 & 1259 & 11934 & 52 \\
\hline 1B & \begin{tabular}{|l|}
0,84 \\
\end{tabular} & 284 & 68841 & 1554 & $\begin{array}{llll} & 1 & 19\end{array}$ & 11006 & 49 \\
\hline $2 \mathrm{~A}$ & 0,8 & 270 & 7268 & 1667 & 1399 & 12861 & 54 \\
\hline $2 \mathrm{~B}$ & 0,8 & 288 & 6780 & 1605 & 1329 & 12277 & 53 \\
\hline $3 \mathrm{~A}$ & 0,73 & 254 & 7105 & 1801 & 1554 & 13616 & 56 \\
\hline $3 \mathrm{~B}$ & 0,71 & 253 & $\begin{array}{|ll|}7187 \\
\end{array}$ & 1749 & 1596 & 13822 & 57 \\
\hline $4 \mathrm{~A}$ & 0,68 & 200 & 10050 & 2490 & 2185 & 17188 & 61 \\
\hline 4B & 0,77 & 282 & 7980 & 1821 & 1442 & 12895 & 53 \\
\hline $5 \mathrm{~A}$ & 0,72 & 270 & 6947 & 1821 & 1086 & 11968 & 56 \\
\hline $5 \mathrm{~B}$ & 0,71 & 288 & \begin{tabular}{|l|}
6367 \\
\end{tabular} & 1729 & $\begin{array}{lll}1 & 103 \\
\end{array}$ & 12826 & 52 \\
\hline $6 \mathrm{~A}$ & 0,57 & 192 & 7907 & 1893 & 1155 & 15230 & 57 \\
\hline $6 \mathrm{~B}$ & 0,56 & 192 & 7667 & 1842 & 991 & 13547 & 57 \\
\hline $7 \mathrm{~A}$ & 0,53 & 176 & 7827 & 2222 & 1388 & 15505 & 59 \\
\hline $7 \mathrm{~B}$ & 0,54 & 194 & 8288 & 2233 & 1345 & 15093 & 61 \\
\hline $8 \mathrm{~A}$ & 0,51 & 174 & 8468 & 2644 & 1414 & 15848 & 62 \\
\hline $8 \mathrm{~B}$ & 0,57 & 218 & 7847 & 2243 & 1388 & 15642 & 57 \\
\hline $9 \mathrm{~A}$ & 3,19 & 150 & 12015 & 277 & 569 & 21995 & 4 \\
\hline $9 \mathrm{~B}$ & 3,45 & 176 & 11000 & 84 & 362 & 17222 & 4 \\
\hline $10 \mathrm{~A}$ & 0,95 & 170 & 9571 & 2206 & 1778 & 16398 & 56 \\
\hline 10B & 0,96 & 218 & 8203 & 1732 & 1456 & 13204 & 53 \\
\hline $11 \mathrm{~A}$ & 0,74 & 186 & 9446 & 2181 & 2083 & 15121 & 60 \\
\hline $12 \mathrm{~B}$ & 0,75 & 198 & 8783 & 1975 & 1848 & 14715 & 57 \\
\hline $12 \mathrm{~A}$ & \begin{tabular}{|l|}
0,62 \\
\end{tabular} & 182 & 8928 & 2047 & 1526 & 15093 & 59 \\
\hline $12 \mathrm{~B}$ & 0,61 & 189 & 9218 & 2161 & 1638 & 12723 & 60 \\
\hline $13 \mathrm{~A}$ & 0,54 & 228 & 7522 & 1885 & 1610 & 12311 & 47 \\
\hline 13B & 0,58 & 255 & 6926 & 1691 & 1428 & 11521 & 45 \\
\hline $14 \mathrm{~A}$ & $0,64 \mid$ & 250 & 6885 & 1615 & 1385 & 11693 & 50 \\
\hline 14B & 0,61 & 259 & 8160 & 1842 & 1764 & 13925 & 55 \\
\hline $15 \mathrm{~A}$ & 0,38 & 122 & 10876 & 3277 & 2858 & 19591 & 56 \\
\hline 15B & 0,4 & 140 & 10485 & 2835 & 2241 & 16157 & 57 \\
\hline $16 \mathrm{~A}$ & 0,47 & 190 & 8551 & 2166 & 2031 & 15024 & 53 \\
\hline $16 \mathrm{~B}$ & 0,44 & 178 & 8736 & 2316 & 2213 & 16054 & 54 \\
\hline
\end{tabular}

* Analysis for $p H$ was done but not for mass of filter cake 
Table A.3 Percentage extraction efficiency of metals during leaching.

\begin{tabular}{|c|c|c|c|c|c|}
\hline Number & Zinc & Alluminium & Iron & Magnesium & Gallium \\
\hline $1 \mathrm{~A}$ & 80 & 31 & 47 & 78 & 33 \\
\hline 1B & $\begin{array}{l}78 \\
\end{array}$ & 31 & 46 & 78 & 34 \\
\hline $2 \mathrm{~A}$ & 78 & 32 & 54 & 87 & 36 \\
\hline $2 \mathrm{~B}$ & 78 & 33 & 55 & 88 & 37 \\
\hline $3 \mathrm{~A}$ & 72 & 32 & 57 & 86 & 35 \\
\hline $3 B$ & 73 & 31 & 58 & 87 & 35 \\
\hline $4 \mathrm{~A}$ & 80 & 35 & 63 & 86 & 30 \\
\hline $4 \mathrm{~B}$ & 90 & 36 & 58 & 91 & 37 \\
\hline $5 \mathrm{~A}$ & 75 & 35 & 42 & 81 & 37 \\
\hline 5B & 73 & 35 & 46 & 92 & 37 \\
\hline $6 \mathrm{~A}$ & 61 & 26 & 32 & 73 & 27 \\
\hline 6B & 59 & 25 & 27 & 65 & 26 \\
\hline $7 \mathrm{~A}$ & 55 & 28 & 35 & 68 & 25 \\
\hline $7 B$ & 64 & 30 & 37 & 73 & 29 \\
\hline $8 \mathrm{~A}$ & 59 & 41 & 35 & 69 & 33 \\
\hline $8 B$ & 68 & 27 & 43 & 85 & 24 \\
\hline $9 \mathrm{~A}$ & 72 & 3 & 12 & 82 & 2 \\
\hline 9B & 77 & 1 & 9 & 76 & 2 \\
\hline $10 \mathrm{~A}$ & 65 & 26 & 43 & 70 & 23 \\
\hline $10 \mathrm{~B}$ & 72 & 27 & 45 & 72 & 28 \\
\hline $11 \mathrm{~A}$ & 70 & 29 & 56 & 70 & 27 \\
\hline 12B & 70 & 28 & 52 & 73 & 28 \\
\hline $12 \mathrm{~A}$ & 65 & 26 & 40 & 69 & 26 \\
\hline $12 \mathrm{~B}$ & 70 & 29 & 44 & 60 & 28 \\
\hline $13 \mathrm{~A}$ & 69 & 30 & 53 & 70 & 26 \\
\hline 13B & 71 & 30 & 52 & 73 & 28 \\
\hline $14 \mathrm{~A}$ & 69 & 28 & 50 & 73 & 30 \\
\hline 14B & 85 & 34 & 65 & 90 & 34 \\
\hline $15 \mathrm{~A}$ & 53 & 28 & 50 & 60 & 17 \\
\hline $15 \mathrm{~B}$ & 59 & 28 & 45 & 57 & 19 \\
\hline $16 \mathrm{~A}$ & 65 & 29 & 55 & 71 & 24 \\
\hline $16 \mathrm{~B}$ & 62 & 29 & 56 & 71 & 24 \\
\hline
\end{tabular}


Table A.4 Analyses of zinc in the filtrates produced.

\begin{tabular}{|c|c|c|c|c|c|c|}
\hline Number & Volume $(\mathrm{ml})$ & Absorbance & $\begin{array}{c}\text { Concentration } \\
(\mathrm{mg} / \mathrm{l}) \times 0,5 \\
\end{array}$ & \begin{tabular}{|c|}
$\begin{array}{c}\text { Concentration } \\
(\mathrm{mg} / \mathrm{l})\end{array}$ \\
\end{tabular} & $\begin{array}{l}\text { Mass } \\
(\mathrm{g})\end{array}$ & $\begin{array}{l}\text { Percentage } \\
\text { extraction }\end{array}$ \\
\hline $1 \mathrm{~A}$ & 260 & 0,383 & 3837 & 7675 & 2,0 & 80 \\
\hline $1 \mathrm{~B}$ & 284 & 0,342 & 3420 & 6841 & 1,9 & 78 \\
\hline $2 \mathrm{~A}$ & 270 & 0,363 & 3634 & 7268 & 2,0 & 78 \\
\hline $2 \mathrm{~B}$ & 288 & 0,339 & 3390 & 6780 & 2,0 & 78 \\
\hline $3 \mathrm{~A}$ & 254 & 0,355 & 3553 & 7105 & 1,8 & 72 \\
\hline $3 \mathrm{~B}$ & 253 & 0,359 & 3593 & 7187 & 1,8 & 73 \\
\hline $4 \mathrm{~A}$ & 200 & 0,446 & 5025 & 10050 & 2,0 & 80 \\
\hline $4 \mathrm{~B}$ & 282 & 0,350 & 3990 & 7980 & 2,3 & 90 \\
\hline $5 \mathrm{~A}$ & 270 & 0,353 & 3474 & 6947 & 1,9 & 75 \\
\hline $5 \mathrm{~B}$ & 288 & 0,324 & 3183 & 6367 & 1,8 & 73 \\
\hline $6 \mathrm{~A}$ & 192 & 0,401 & 3954 & 7907 & 1,5 & 61 \\
\hline $6 \mathrm{~B}$ & 192 & 0,389 & 3834 & 7667 & 1,5 & 59 \\
\hline $7 \mathrm{~A}$ & 176 & 0,397 & 3914 & 7827 & 1,4 & 55 \\
\hline $7 B$ & 194 & 0,420 & 4144 & 8288 & 1,6 & 64 \\
\hline $8 \mathrm{~A}$ & 174 & 0,429 & 4234 & 8468 & 1,5 & 59 \\
\hline $8 B$ & 218 & 0,398 & 3924 & 7847 & 1,7 & 68 \\
\hline $9 \mathrm{~A}$ & 150 & 0,587 & 6008 & 12015 & 1,8 & 72 \\
\hline $9 \mathrm{~B}$ & 176 & 0,538 & 5500 & 11000 & 1,9 & 77 \\
\hline $10 \mathrm{~A}$ & 170 & 0,469 & 4785 & 9571 & 1,6 & 65 \\
\hline $10 \mathrm{~B}$ & 218 & 0,403 & 4102 & 8203 & 1,8 & 72 \\
\hline $11 \mathrm{~A}$ & 186 & 0,463 & 4723 & 9446 & 1,8 & 70 \\
\hline $12 B$ & 198 & 0,431 & 4392 & 8783 & 1,7 & 70 \\
\hline $12 \mathrm{~A}$ & 182 & 0,438 & 4464 & 8928 & 1,6 & 65 \\
\hline 12B & 189 & 0,452 & 4609 & 9218 & 1,7 & 70 \\
\hline $13 \mathrm{~A}$ & 228 & 0,373 & 3761 & 7522 & 1,7 & 69 \\
\hline $13 \mathrm{~B}$ & 255 & 0,344 & 3463 & 6926 & 1,8 & 71 \\
\hline $14 \mathrm{~A}$ & 250 & 0,342 & 3442 & 6885 & 1,7 & 69 \\
\hline $14 \mathrm{~B}$ & 259 & 0,404 & 4080 & 8160 & 2,1 & 85 \\
\hline $15 \mathrm{~A}$ & 122 & 0,536 & 5438 & 10876 & 1,3 & 53 \\
\hline $15 \mathrm{~B}$ & 140 & 0,517 & 5242 & 10485 & 1,5 & 59 \\
\hline $16 \mathrm{~A}$ & 190 & 0,423 & 4275 & 8551 & 1,6 & 65 \\
\hline $16 \mathrm{~B}$ & 178 & 0,432 & 4368 & 8736 & 1,6 & 62 \\
\hline
\end{tabular}


Table A.5 Analyses of aluminium in the filtrates produced.

\begin{tabular}{|c|c|c|c|c|c|c|}
\hline Number & Volume (ml) & Absorbance & $\begin{array}{l}\text { Concentration } \\
(\mathrm{mg} / \mathrm{l}) \times 0,01\end{array}$ & $\begin{array}{c}\text { Concentration } \\
(\mathrm{mg} / \mathrm{l})\end{array}$ & $\begin{array}{l}\text { Mass } \\
(\mathrm{g})\end{array}$ & $\begin{array}{l}\text { Percentage } \\
\text { extraction }\end{array}$ \\
\hline $1 \mathrm{~A}$ & 260 & 0,161 & 16,8 & 1677 & 0,44 & 31 \\
\hline 1B & 284 & 0,149 & 15,5 & 1554 & 0,44 & 31 \\
\hline $2 \mathrm{~A}$ & 270 & 0,160 & 16,7 & 1667 & 0,45 & 32 \\
\hline $2 \mathrm{~B}$ & 288 & 0,154 & 16,1 & 1605 & 0,46 & 33 \\
\hline $3 \mathrm{~A}$ & 254 & 0,173 & 18,0 & 1801 & 0,46 & 32 \\
\hline $3 \mathrm{~B}$ & 253 & 0,168 & 17,5 & 1749 & 0,44 & 31 \\
\hline $4 \mathrm{~A}$ & 200 & 0,240 & 24,9 & 2490 & 0,50 & 35 \\
\hline $4 B$ & 282 & 0,175 & 18,2 & 1821 & 0,51 & 36 \\
\hline $5 \mathrm{~A}$ & 270 & 0,175 & 18,2 & 1821 & 0,49 & 35 \\
\hline $5 B$ & 288 & 0,166 & 17,3 & 1729 & 0,50 & 35 \\
\hline $6 \mathrm{~A}$ & 192 & 0,182 & 18,9 & 1893 & 0,36 & 26 \\
\hline $6 \mathrm{~B}$ & 192 & 0,177 & 18,4 & 1842 & 0,35 & 25 \\
\hline $7 \mathrm{~A}$ & 176 & 0,214 & 22,2 & 2222 & 0,39 & 28 \\
\hline $7 \mathrm{~B}$ & 194 & 0,215 & 22,3 & 2233 & 0,43 & 30 \\
\hline $8 \mathrm{~A}$ & 218 & 0,255 & 26,4 & 2644 & 0,58 & 41 \\
\hline $8 \mathrm{~B}$ & 174 & 0,216 & 22,4 & 2243 & 0,39 & 27 \\
\hline $9 \mathrm{~A}$ & 150 & 0,023 & 2,8 & 277 & 0,04 & 3 \\
\hline 9B & 176 & 0,005 & 0,8 & 84 & 0,01 & 1 \\
\hline $10 \mathrm{~A}$ & 170 & 0,202 & 22,1 & 2206 & 0,37 & 26 \\
\hline 10B & 218 & 0,158 & 17,3 & 1732 & 0,38 & 27 \\
\hline $11 \mathrm{~A}$ & 186 & 0,210 & 21,8 & 2181 & 0,41 & 29 \\
\hline $12 B$ & 198 & 0,190 & 19,8 & 1975 & 0,39 & 28 \\
\hline $12 \mathrm{~A}$ & 182 & 0,197 & 20,5 & 2047 & 0,37 & 26 \\
\hline $12 \mathrm{~B}$ & 189 & 0,208 & 21,6 & 2161 & 0,41 & 29 \\
\hline $13 \mathrm{~A}$ & 228 & 0,171 & 18,8 & 1885 & 0,43 & 30 \\
\hline $13 \mathrm{~B}$ & 255 & 0,153 & 16,9 & 1691 & 0,43 & 30 \\
\hline $14 \mathrm{~A}$ & 250 & 0,146 & 16,2 & 1615 & 0,40 & 28 \\
\hline $14 \mathrm{~B}$ & 259 & 0,167 & 18,4 & 1842 & 0,48 & 34 \\
\hline $15 \mathrm{~A}$ & 122 & 0,300 & 32,8 & 3277 & 0,40 & 28 \\
\hline $15 \mathrm{~B}$ & 140 & 0,259 & 28,3 & 2835 & 0,40 & 28 \\
\hline $16 \mathrm{~A}$ & 190 & 0,197 & 21,7 & 2166 & 0,41 & 29 \\
\hline $16 \mathrm{~B}$ & 178 & 0,211 & 23,2 & 2317 & 0,41 & 29 \\
\hline
\end{tabular}


Table A.6 Analyses of gallium for the filtrates produced.

\begin{tabular}{|c|c|c|c|c|c|}
\hline Number. & $\begin{array}{c}\text { Volume } \\
(\mathrm{ml})\end{array}$ & Absorbance & $\begin{array}{c}\text { Concentration } \\
(\mathrm{mg} / \mathrm{l})\end{array}$ & $\begin{array}{c}\text { Mass } \\
(\mathrm{g})\end{array}$ & $\begin{array}{l}\text { Percentage } \\
\text { Extraction }\end{array}$ \\
\hline $1 \mathrm{~A}$ & 260 & 0,170 & 52 & 0,014 & 33 \\
\hline $1 \mathrm{~B}$ & 284 & 0,158 & 49 & 0,014 & 34 \\
\hline $2 \mathrm{~A}$ & 270 & 0,176 & 54 & 0,015 & 36 \\
\hline $2 B$ & 288 & 0,172 & 53 & 0,015 & 37 \\
\hline $3 \mathrm{~A}$ & 254 & 0,182 & 56 & 0,014 & 35 \\
\hline $3 B$ & 253 & 0,184 & 57 & 0,014 & 35 \\
\hline $4 \mathrm{~A}$ & 200 & 0,198 & 61 & 0,012 & 30 \\
\hline $4 B$ & 282 & 0,173 & 53 & 0,015 & 37 \\
\hline $5 \mathrm{~A}$ & 270 & 0,180 & 56 & 0,015 & 37 \\
\hline $5 B$ & 288 & 0,169 & 52 & 0,015 & 37 \\
\hline $6 \mathrm{~A}$ & 192 & 0,217 & 57 & 0,011 & 27 \\
\hline $6 B$ & 192 & 0,214 & 57 & 0,011 & 26 \\
\hline $7 \mathrm{~A}$ & 176 & 0,223 & 59 & 0,010 & 25 \\
\hline $7 B$ & 194 & 0,231 & 61 & 0,012 & 29 \\
\hline $8 \mathrm{~A}$ & 218 & 0,220 & 62 & 0,013 & 33 \\
\hline $8 B$ & 174 & 0,203 & 57 & 0,010 & 24 \\
\hline $9 \mathrm{~A}$ & 150 & 0,021 & 4 & 0,001 & 2 \\
\hline $9 B$ & 176 & 0,019 & 4 & 0,001 & 2 \\
\hline $10 \mathrm{~A}$ & 170 & 0,200 & 56 & 0,010 & 23 \\
\hline $10 \mathrm{~B}$ & 218 & 0,189 & 53 & 0,012 & 28 \\
\hline $11 \mathrm{~A}$ & 186 & 0,213 & 60 & 0,011 & 27 \\
\hline $12 \mathrm{~B}$ & 198 & 0,203 & 57 & 0,011 & 28 \\
\hline $12 \mathrm{~A}$ & 182 & 0,215 & 59 & 0,011 & 26 \\
\hline $12 \mathrm{~B}$ & 189 & 0,218 & 60 & 0,011 & 28 \\
\hline $13 \mathrm{~A}$ & 228 & 0,173 & 47 & 0,011 & 26 \\
\hline $13 B$ & 255 & 0,166 & 45 & 0,012 & 28 \\
\hline $14 \mathrm{~A}$ & 250 & 0,181 & 50 & 0,012 & 30 \\
\hline $14 B$ & 259 & 0,198 & 55 & 0,014 & 34 \\
\hline $15 \mathrm{~A}$ & 122 & 0,204 & 56 & 0,007 & 17 \\
\hline $15 B$ & 140 & 0,206 & 57 & 0,008 & 19 \\
\hline $16 \mathrm{~A}$ & 190 & 0,192 & 53 & 0,010 & 24 \\
\hline $16 \mathrm{~B}$ & 178 & 0,197 & 54 & 0,010 & 24 \\
\hline
\end{tabular}


Table A.7 Analyses of iron for the filtrates produced.

\begin{tabular}{|c|c|c|c|c|c|c|}
\hline Number & Volume. $(\mathrm{ml})$ & Absorbance & $\begin{array}{c}\text { Concentration } \\
(\mathrm{mg} / \mathrm{l}) \times 0,001\end{array}$ & $\begin{array}{c}\text { Concentration } \\
(\mathrm{mg} / \mathrm{l})\end{array}$ & Mass $(\mathrm{g})$ & $\begin{array}{c}\text { Percentage } \\
\text { extraction }\end{array}$ \\
\hline 1A & 260 & 0,113 & 1,3 & 1259 & 0,33 & 47 \\
\hline 1B & 284 & 0,103 & 1,1 & 1119 & 0,32 & 46 \\
\hline 2A & 270 & 0,123 & 1,4 & 1399 & 0,38 & 54 \\
\hline 2B & 288 & 0,118 & 1,3 & 1329 & 0,38 & 55 \\
\hline 3A & 254 & 0,134 & 1,6 & 1554 & 0,39 & 57 \\
\hline 3B & 253 & 0,137 & 1,6 & 1596 & 0,40 & 58 \\
\hline 4A & 200 & 0,179 & 2,2 & 2185 & 0,44 & 63 \\
\hline 4B & 282 & 0,126 & 1,4 & 1442 & 0,41 & 58 \\
\hline 5A & 270 & 0,129 & 1,1 & 1086 & 0,29 & 42 \\
\hline 5B & 288 & 0,131 & 1,1 & 1103 & 0,32 & 46 \\
\hline 6A & 192 & 0,137 & 1,2 & 1155 & 0,22 & 32 \\
\hline 6B & 192 & 0,118 & 1,0 & 991 & 0,19 & 27 \\
\hline 7A & 176 & 0,164 & 1,4 & 1388 & 0,24 & 35 \\
\hline 7B & 194 & 0,159 & 1,3 & 1345 & 0,26 & 37 \\
\hline 8A & 174 & 0,167 & 1,4 & 1414 & 0,25 & 35 \\
\hline 8B & 218 & 0,164 & 1,4 & 1388 & 0,30 & 43 \\
\hline 9A & 150 & 0,069 & 0,6 & 569 & 0,09 & 12 \\
\hline 9B & 176 & 0,045 & 0,4 & 362 & 0,06 & 9 \\
\hline 10A & 170 & 0,150 & 1,8 & 1778 & 0,30 & 43 \\
\hline 10B & 218 & 0,127 & 1,5 & 1456 & 0,32 & 45 \\
\hline 11A & 186 & 0,246 & 3,1 & 2083 & 0,39 & 56 \\
\hline 12B & 198 & 0,155 & 1,8 & 1848 & 0,37 & 52 \\
\hline 12A & 182 & 0,180 & 1,5 & 1526 & 0,28 & 40 \\
\hline 12B & 189 & 0,140 & 1,6 & 1638 & 0,31 & 44 \\
\hline 13A & 228 & 0,138 & 1,6 & 1610 & 0,37 & 53 \\
\hline 13B & 255 & 0,125 & 1,4 & 1428 & 0,36 & 52 \\
\hline 14A & 250 & 0,122 & 1,4 & 1385 & 0,35 & 50 \\
\hline 14B & 259 & 0,149 & 1,8 & 1764 & 0,46 & 65 \\
\hline 15A & 122 & 0,227 & 2,9 & 2858 & 0,35 & 50 \\
\hline 15B & 140 & 0,183 & 2,2 & 2241 & 0,31 & 45 \\
\hline 16A & 190 & 0,168 & 2,0 & 2031 & 0,39 & 55 \\
\hline 16B & 178 & 0,181 & 2,2 & 2213 & 0,39 & 56 \\
\hline & & & & & & \\
\hline
\end{tabular}


Table A.8 Analyses of magnesium for the filtrates produced.

\begin{tabular}{|c|c|c|c|c|c|c|}
\hline Number & $\begin{array}{c}\text { Volume } \\
(\mathrm{ml})\end{array}$ & Absorbance & $\begin{array}{c}\text { Concentration } \\
(\mathrm{mg} / \mathrm{l}) \times 0,001\end{array}$ & $\begin{array}{c}\text { Concentration } \\
(\mathrm{mg} / \mathrm{l})\end{array}$ & Mass $(\mathrm{g})$ & $\begin{array}{c}\text { Percentage } \\
\text { extraction }\end{array}$ \\
\hline 1A & 260 & 0,360 & 12 & 11934 & 3,10 & 78 \\
\hline 1B & 284 & 0,333 & 11 & 11006 & 3,13 & 78 \\
\hline 2A & 270 & 0,387 & 13 & 12861 & 3,47 & 87 \\
\hline 2B & 288 & 0,370 & 12 & 12277 & 3,54 & 88 \\
\hline 3A & 254 & 0,409 & 14 & 13616 & 3,46 & 86 \\
\hline 3B & 253 & 0,415 & 14 & 13822 & 3,50 & 87 \\
\hline 4A & 200 & 0,513 & 17 & 17188 & 3,44 & 86 \\
\hline 4B & 282 & 0,388 & 13 & 12895 & 3,64 & 91 \\
\hline 5A & 270 & 0,361 & 12 & 11968 & 3,23 & 81 \\
\hline 5B & 288 & 0,386 & 13 & 12826 & 3,69 & 92 \\
\hline 6A & 192 & 0,456 & 15 & 15230 & 2,92 & 73 \\
\hline 6B & 192 & 0,407 & 14 & 13547 & 2,60 & 65 \\
\hline 7A & 176 & 0,464 & 16 & 15505 & 2,73 & 68 \\
\hline 7B & 194 & 0,452 & 15 & 15093 & 2,93 & 73 \\
\hline 8A & 174 & 0,474 & 16 & 15848 & 2,76 & 69 \\
\hline 8B & 218 & 0,468 & 16 & 15642 & 3,41 & 85 \\
\hline 9A & 150 & 0,653 & 22 & 21995 & 3,30 & 82 \\
\hline 9B & 176 & 0,514 & 17 & 17222 & 3,03 & 76 \\
\hline 10A & 170 & 0,490 & 16 & 16398 & 2,79 & 70 \\
\hline 10B & 218 & 0,397 & 13 & 13204 & 2,88 & 72 \\
\hline 11A & 186 & 0,673 & 23 & 15121 & 2,81 & 70 \\
\hline 12B & 198 & 0,441 & 15 & 14715 & 2,91 & 73 \\
\hline 12A & 182 & 0,452 & 15 & 15093 & 2,75 & 69 \\
\hline 12B & 189 & 0,383 & 13 & 12723 & 2,40 & 60 \\
\hline 13A & 228 & 0,371 & 12 & 12311 & 2,81 & 70 \\
\hline 13B & 255 & 0,348 & 12 & 11521 & 2,94 & 73 \\
\hline 14A & 250 & 0,353 & 12 & 11693 & 2,92 & 73 \\
\hline 14B & 259 & 0,418 & 14 & 13925 & 3,61 & 90 \\
\hline 15A & 122 & 0,583 & 20 & 19591 & 2,39 & 60 \\
\hline 15B & 140 & 0,483 & 16 & 16157 & 2,26 & 57 \\
\hline 16A & 190 & 0,450 & 15 & 15024 & 2,85 & 71 \\
\hline 16B & 178 & 0,480 & 16 & 16054 & 2,86 & 71 \\
\hline
\end{tabular}




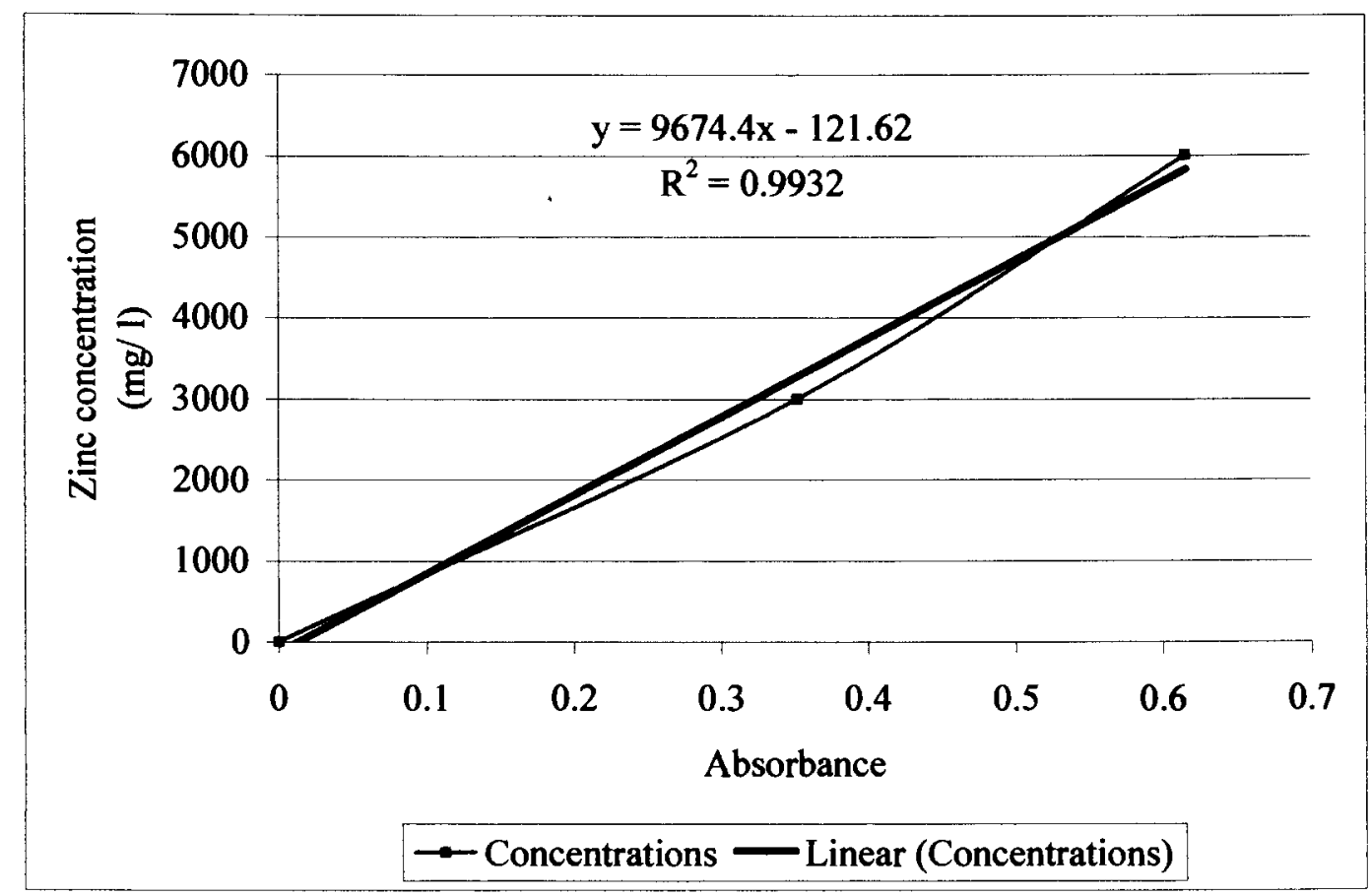

Figure A.1 Calibration curve for zinc concentration against absorbance.

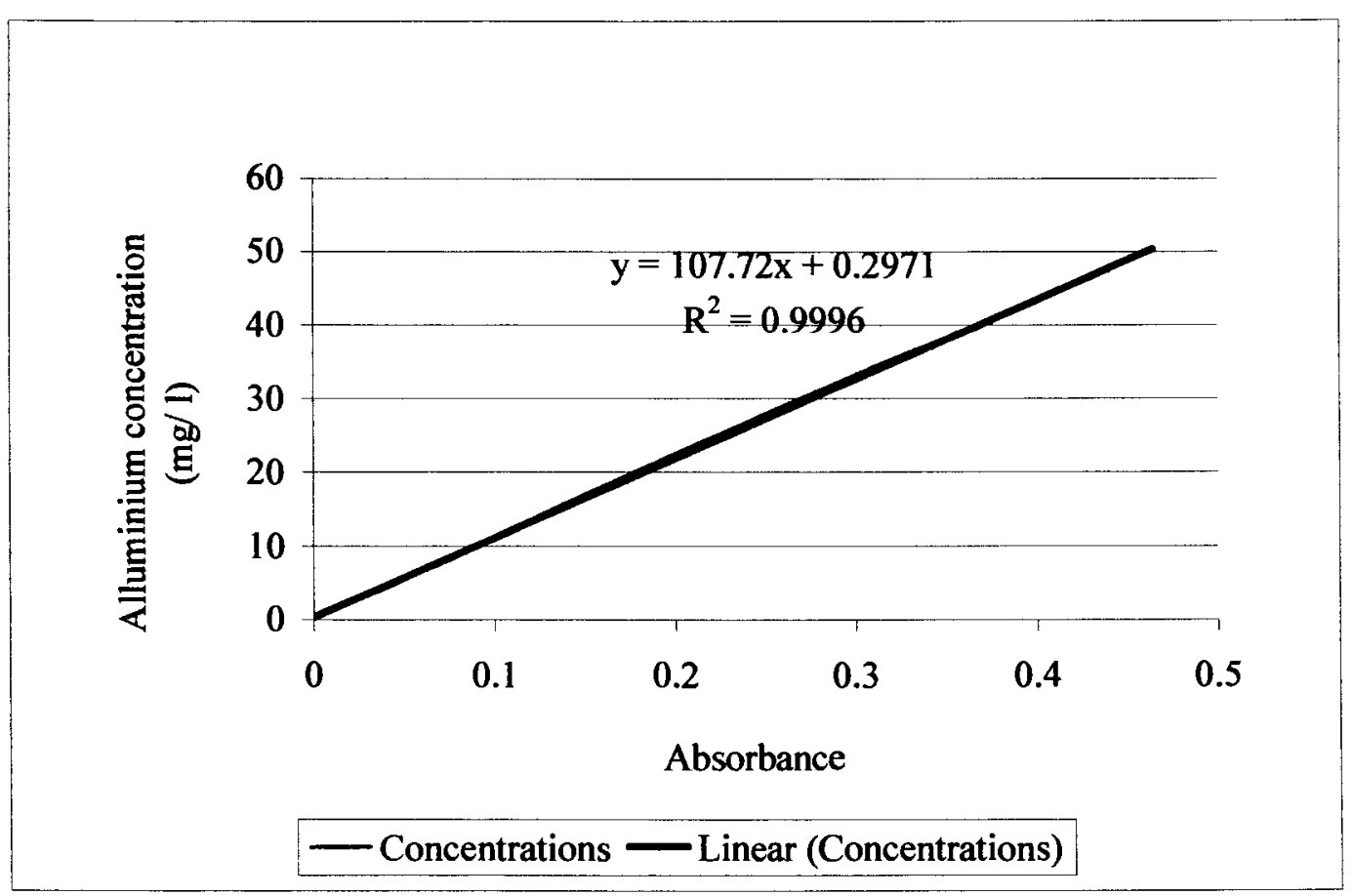

Figure A.2 Calibration curve for alluminium concentration against absorbance. 


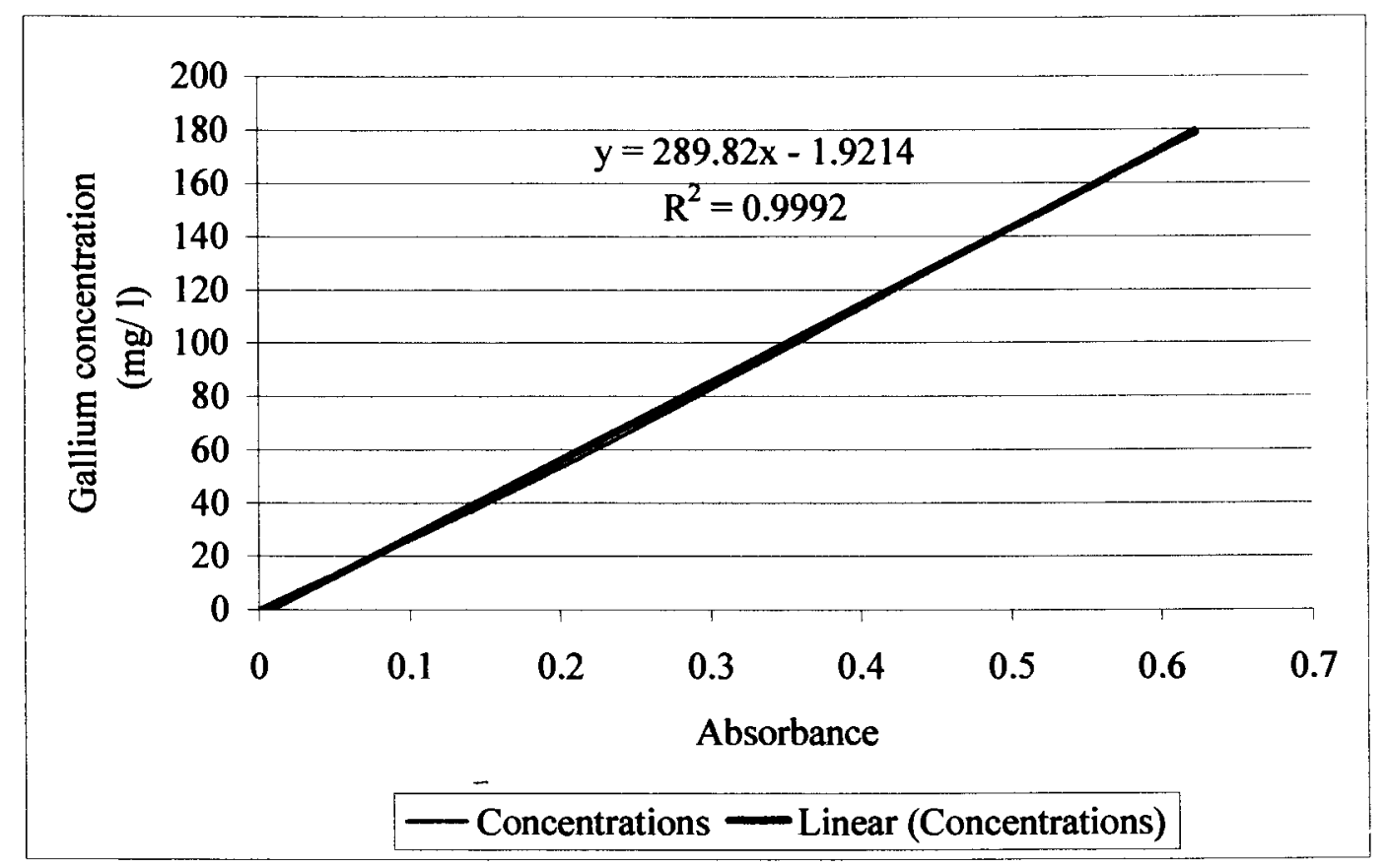

Figure A.3 Calibration curve for gallium concentration against absorbance.

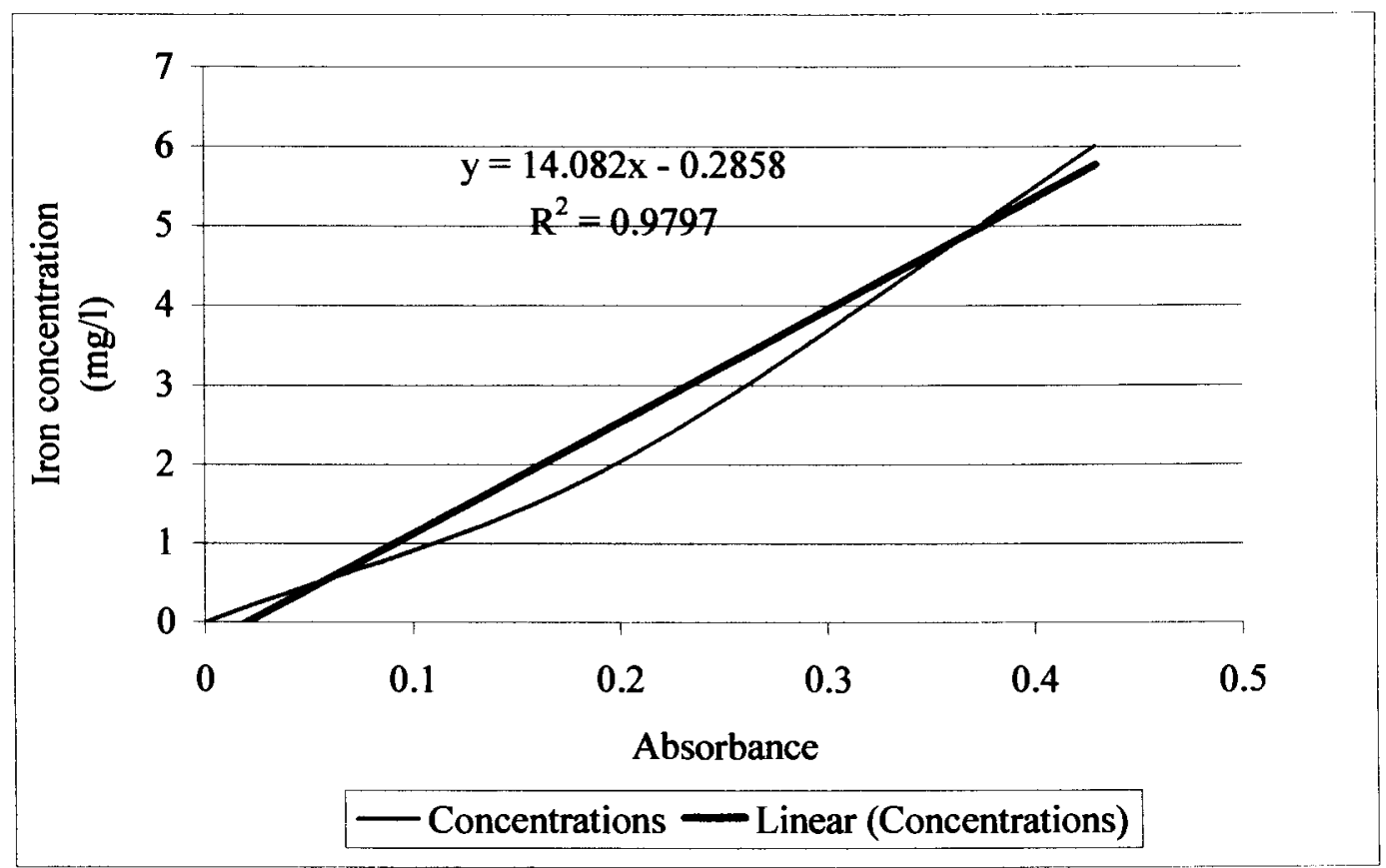

Figure A.4 Calibration curve for iron concentration against absorbance. 


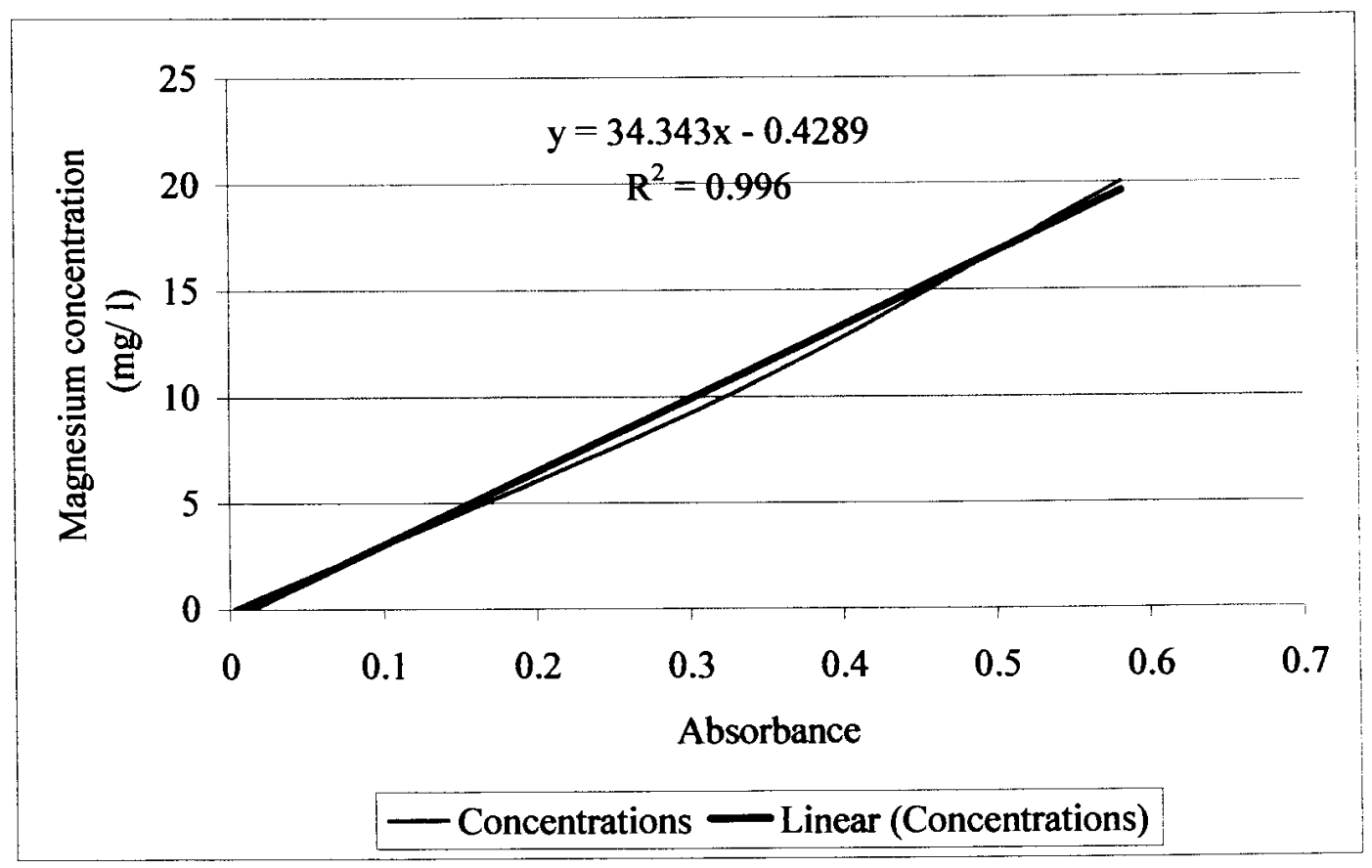

Figure A.5 Calibration curve for magnesium concentration against absorbance. 


\section{Appendix B}

\section{Raw data for the second set of experiments}

(Volumes of water in first and second step (typically): 40 and $200 \mathrm{ml}$ )

Table B.1 Conditions for the second set of leaching experiments.

\begin{tabular}{|c|c|c|c|c|}
\hline Number & $\begin{array}{c}\text { Temperature } \\
\left({ }^{\circ} \mathrm{C}\right)\end{array}$ & Duration (hrs) & $\begin{array}{l}\text { Volume acid added } \\
(\mathrm{ml})\end{array}$ & $\begin{array}{c}\text { Volume water added } \\
(\mathrm{ml})\end{array}$ \\
\hline $17 \mathrm{~A}$ & 97 & 24 & 18,4 & 100 \\
\hline 17B & 97 & 24 & 18,4 & 100 \\
\hline $18 \mathrm{~A}$ & 97 & 24 & 18,4 & 150 \\
\hline $18 \mathrm{~B}$ & 97 & 24 & 18,4 & 150 \\
\hline $19 \mathrm{~A}$ & 97 & 24 & 18,4 & 250 \\
\hline 19B & 97 & 24 & 18,4 & 250 \\
\hline $20 \mathrm{~A}$ & 97 & 24 & 18,4 & 200 \\
\hline $20 \mathrm{~B}$ & 97 & 24 & 18,4 & 200 \\
\hline $21 \mathrm{~A}$ & 97 & 0 & 4,6 & 200 \\
\hline 21B & 97 & 0 & 4,6 & 200 \\
\hline $22 \mathrm{~A}$ & 97 & 6 & 18,4 & 200 \\
\hline 22B & 97 & 6 & 18,4 & 200 \\
\hline $23 \mathrm{~A}$ & 97 & 12 & 18,4 & 200 \\
\hline $23 \mathrm{~B}$ & 97 & 12 & 18,4 & 200 \\
\hline $24 \mathrm{~A}$ & 97 & 0 & 18,4 & 200 \\
\hline $24 \mathrm{~B}$ & 97 & 0 & 18,4 & 200 \\
\hline $25 \bar{A}$ & 97 & 3 & 18,4 & 200 \\
\hline 25B & 97 & 3 & 18,4 & 200 \\
\hline $26 \mathrm{~A}$ & 97 & 9 & 18,4 & 200 \\
\hline $26 \mathrm{~B}$ & 97 & 9 & 18,4 & 200 \\
\hline $27 \mathrm{~A}$ & 50 & 24 & 18,4 & 200 \\
\hline $27 \mathrm{~B}$ & 50 & 24 & 18,4 & 200 \\
\hline $28 \mathrm{~A}$ & 75 & 24 & 18,4 & 200 \\
\hline $28 B$ & 75 & 24 & 18,4 & 200 \\
\hline $29 A$ & 28 & 24 & 18,4 & 200 \\
\hline 29B & 28 & 24 & 18,4 & 200 \\
\hline $30 \mathrm{~A}$ & 97 & 24 & 18,4 & 200 \\
\hline 30B & 97 & 24 & 18,4 & 200 \\
\hline $31 \mathrm{~A}$ & 97 & 48 & 18,4 & 200 \\
\hline $31 \mathrm{~B}$ & 97 & 48 & 18,4 & 200 \\
\hline $32 \mathrm{~A}$ & 97 & 24 & 4,6 & 200 \\
\hline 32B & 97 & 24 & 4,6 & 200 \\
\hline $33 \mathrm{~A}$ & 97 & 24 & 9,2 & 200 \\
\hline 33B & 97 & 24 & 9,2 & 200 \\
\hline
\end{tabular}


Table B.2 Concentrations of metals in filtrate after leaching $(\mathrm{mg} / \mathrm{l}) \star$

\begin{tabular}{|c|c|c|c|c|c|c|c|}
\hline Number & $\begin{array}{c}\text { Mass of filter cake } \\
(\mathrm{g})\end{array}$ & $\begin{array}{l}\text { Volume of } \\
\text { filtrate }(\mathrm{ml})\end{array}$ & Zinc & Alluminium & Iron & Magnesium & Gallium \\
\hline $17 \mathrm{~A}$ & $* *$ & 100 & 10878 & 233 & 1803 & 42673 & 25 \\
\hline $17 \mathrm{~B}$ & ** & 110 & 11068 & 244 & 1716 & 37445 & 30 \\
\hline $18 \mathrm{~A}$ & ** & 172 & 9793 & 340 & 1257 & 34450 & 41 \\
\hline $18 \mathrm{~B}$ & ** & 156 & 10022 & 316 & 1364 & 38153 & 36 \\
\hline $19 \mathrm{~A}$ & $* *$ & 240 & 8214 & 359 & 979 & 31292 & 43 \\
\hline $19 \mathrm{~B}$ & $* *$ & 264 & 7681 & 363 & 884 & 31346 & 41 \\
\hline $20 \mathrm{~A}$ & 19 & 216 & 8473 & 348 & 1108 & 21528 & 46 \\
\hline 20B & 19 & 228 & 7966 & 352 & 1062 & 30910 & 44 \\
\hline $21 \mathrm{~A}$ & 24 & 214 & 5838 & 14 & 0 & 22851 & 4 \\
\hline $21 \mathrm{~B}$ & 24 & 313 & 5047 & 32 & 0 & 18985 & 3 \\
\hline $22 \mathrm{~A}$ & 18 & 213 & 8209 & 333 & 1021 & 30420 & 48 \\
\hline 22B & 18 & 233 & 7682 & 333 & 1016 & 28024 & 45 \\
\hline $23 \mathrm{~A}$ & 18 & 225 & 8108 & 335 & 1116 & 30312 & 47 \\
\hline $23 B$ & 18 & 212 & 8372 & 333 & 1712 & 31455 & 47 \\
\hline $24 \mathrm{~A}$ & 21 & 223 & 7338 & 346 & 859 & 20852 & 48 \\
\hline $24 \mathrm{~B}$ & 21 & 228 & 7480 & 368 & 905 & 28623 & 47 \\
\hline $25 \mathrm{~A}$ & 18 & 215 & 8169 & 325 & 1021 & 30094 & 41 \\
\hline $25 B$ & 18 & 230 & 7986 & 365 & 992 & 29222 & 41 \\
\hline $26 \mathrm{~A}$ & 18 & 210 & 8473 & 368 & 1103 & 31564 & 1 \\
\hline 26B & 18 & 214 & 8169 & 374 & 1137 & 32544 & 1 \\
\hline $27 \mathrm{~A}$ & 19 & 218 & 7885 & 383 & 971 & 28242 & 34 \\
\hline $27 \mathrm{~B}$ & 19 & 224 & 7601 & 369 & 1145 & 25356 & 38 \\
\hline $28 \mathrm{~A}$ & 19 & 205 & 7703 & 419 & 1145 & 31237 & 45 \\
\hline $28 \mathrm{~B}$ & 19 & 217 & 7824 & 390 & 1062 & 31401 & 48 \\
\hline $29 \mathrm{~A}$ & 20 & 229 & 7257 & 330 & 855 & 28079 & 42 \\
\hline 29B & 19 & 221 & 7682 & 330 & 1215 & 29331 & 47 \\
\hline $30 \mathrm{~A}$ & 17 & 222 & 8027 & 351 & 1091 & 31673 & 43 \\
\hline $30 \mathrm{~B}$ & 17 & 207 & 8574 & 334 & 1145 & 33851 & 47 \\
\hline $31 \mathrm{~A}$ & 17 & 198 & 8230 & 346 & 1199 & 32054 & 43 \\
\hline $31 \mathrm{~B}$ & 18 & 183 & 10216 & 346 & 1344 & 34940 & 42 \\
\hline $32 \mathrm{~A}$ & 26 & 196 & 953 & 55 & 0 & 23724 & 0 \\
\hline $32 \mathrm{~B}$ & 26 & 206 & 669 & 56 & 0 & 23995 & 0 \\
\hline $33 \mathrm{~A}$ & 21 & 184 & 9628 & 147 & 0 & 25272 & 6 \\
\hline $33 \mathrm{~B}$ & 21 & 176 & 10196 & 145 & 0 & 42836 & 5 \\
\hline $18 \mathrm{~A}$ & $\star \star$ & $\hbar \hbar$ & 953 & 55 & 0 & 23724 & 0 \\
\hline $18 \mathrm{~B}$ & 26 & 206 & 669 & 56 & 0 & 23995 & 0 \\
\hline $19 \mathrm{~A}$ & 21 & 184 & 9628 & 147 & 0 & 25272 & 6 \\
\hline 19B & 21 & 176 & 10196 & 145 & 0 & 42836 & 5 \\
\hline
\end{tabular}

* No analysis for $\mathrm{pH}$ was done.

** Data were lost. 
Table B.3 Percentage extraction of metals during leaching.

\begin{tabular}{|c|c|c|c|c|c|}
\hline Number & Zinc & Alluminium & Iron & Magnesium & Gallium \\
\hline $17 \mathrm{~A}$ & 44 & 2 & 23 & 92 & 6 \\
\hline $17 \mathrm{~B}$ & 49 & 3 & 24 & 89 & 8 \\
\hline $18 \mathrm{~A}$ & 67 & 6 & 28 & 127 & 17 \\
\hline $18 \mathrm{~B}$ & 63 & 5 & 27 & 128 & 14 \\
\hline $19 \mathrm{~A}$ & 79 & 9 & 30 & 162 & 25 \\
\hline 19B & 81 & 10 & 30 & 178 & 26 \\
\hline $20 \mathrm{~A}$ & 73 & 8 & 31 & 100 & 24 \\
\hline $20 \mathrm{~B}$ & 73 & 8 & 31 & 152 & 24 \\
\hline $21 \mathrm{~A}$ & 50 & 0 & 0 & 105 & 2 \\
\hline $21 \mathrm{~B}$ & 63 & 1 & 0 & 128 & 2 \\
\hline $22 \mathrm{~A}$ & 70 & 7 & 28 & 139 & 25 \\
\hline 22B & 72 & 8 & 30 & 140 & 26 \\
\hline $23 \mathrm{~A}$ & 73 & 8 & 32 & 147 & 26 \\
\hline 23B & 71 & 7 & 47 & 143 & 24 \\
\hline $24 \mathrm{~A}$ & 65 & 8 & 25 & 100 & 26 \\
\hline $24 \mathrm{~B}$ & 68 & 8 & 26 & 140 & 26 \\
\hline $25 \mathrm{~A}$ & 70 & 7 & 28 & 139 & 22 \\
\hline $25 B$ & 73 & 8 & 29 & 145 & 23 \\
\hline $26 \mathrm{~A}$ & 71 & 8 & 30 & 143 & 1 \\
\hline $26 \mathrm{~B}$ & 70 & 8 & 31 & 150 & 0 \\
\hline $27 \mathrm{~A}$ & 69 & 8 & 27 & 132 & 18 \\
\hline 27B & 68 & 8 & 33 & 122 & 21 \\
\hline $28 \mathrm{~A}$ & 63 & 9 & 30 & 138 & 23 \\
\hline $28 \mathrm{~B}$ & 68 & 8 & 30 & 147 & 25 \\
\hline $29 \mathrm{~A}$ & 66 & 8 & 25 & 138 & 24 \\
\hline $29 B$ & 68 & 7 & 34 & 139 & 26 \\
\hline $30 \mathrm{~A}$ & 71 & 8 & 31 & 151 & 23 \\
\hline $30 \mathrm{~B}$ & 71 & 7 & 30 & 151 & 24 \\
\hline $31 \mathrm{~A}$ & 65 & 7 & 30 & 136 & 21 \\
\hline 31B & 75 & 6 & 32 & 138 & 19 \\
\hline $32 \mathrm{~A}$ & 7 & 1 & 0 & 100 & 0 \\
\hline $32 \mathrm{~B}$ & 6 & 1 & 0 & 106 & 0 \\
\hline $33 \mathrm{~A}$ & 71 & 3 & 0 & 100 & 2 \\
\hline 33B & 72 & 3 & 0 & 162 & 2 \\
\hline
\end{tabular}


Table B.4 Analyses of zinc in the filtrates produced.

\begin{tabular}{|c|c|c|c|c|c|}
\hline Number & Absorbance & $\begin{array}{c}\text { Concentration } \\
(\mathrm{mg} / \mathrm{l}) \times 0,5\end{array}$ & $\begin{array}{c}\text { Concentration } \\
(\mathrm{mg} / \mathrm{l})\end{array}$ & $\begin{array}{l}\text { Mass in filtrate } \\
(\mathrm{g})\end{array}$ & $\begin{array}{l}\text { Percentage } \\
\text { extraction }\end{array}$ \\
\hline $17 \mathrm{~A}$ & 0,580 & 5439 & 10878 & 1,1 & 44 \\
\hline 17B & 0,590 & 5534 & 11068 & 1,2 & 49 \\
\hline $18 \mathrm{~A}$ & 0,523 & 4897 & 9793 & 1,7 & 67 \\
\hline $18 \mathrm{~B}$ & 0,535 & 5011 & 10022 & 1,6 & 63 \\
\hline $19 \mathrm{~A}$ & 0,440 & 4107 & 8214 & 2,0 & 79 \\
\hline 19B & 0,412 & 3840 & 7681 & 2,0 & 81 \\
\hline $20 \mathrm{~A}$ & 0,418 & 4236 & 8473 & 1,8 & 73 \\
\hline $20 \mathrm{~B}$ & 0,393 & 3983 & 7966 & 1,8 & 73 \\
\hline $21 \mathrm{~A}$ & 0,288 & 2919 & 5838 & 1,2 & 50 \\
\hline $21 \mathrm{~B}$ & 0,249 & 2524 & 5047 & 1,6 & 63 \\
\hline $22 \mathrm{~A}$ & 0,405 & 4105 & 8209 & 1,7 & 70 \\
\hline $22 B$ & 0,379 & 3841 & 7682 & 1,8 & 72 \\
\hline $23 \mathrm{~A}$ & 0,400 & 4054 & 8108 & 1,8 & 73 \\
\hline 23B & 0,413 & 4186 & 8372 & 1,8 & 71 \\
\hline $24 \mathrm{~A}$ & 0,362 & 3669 & 7338 & 1,6 & 65 \\
\hline $24 \mathrm{~B}$ & 0,369 & 3740 & 7480 & 1,7 & 68 \\
\hline $25 \mathrm{~A}$ & 0,403 & 4084 & 8169 & 1,8 & 70 \\
\hline $25 B$ & 0,394 & 3993 & 7986 & 1,8 & 73 \\
\hline $26 \mathrm{~A}$ & 0,418 & 4236 & 8473 & 1,8 & 71 \\
\hline 26B & 0,403 & 4084 & 8169 & 1,7 & 70 \\
\hline $27 \mathrm{~A}$ & 0,389 & 3943 & 7885 & 1,7 & 69 \\
\hline 27B & 0,375 & 3801 & 7601 & 1,7 & 68 \\
\hline $28 \mathrm{~A}$ & 0,380 & 3851 & 7703 & 1,6 & 63 \\
\hline 28B & 0,386 & 3912 & 7824 & 1,7 & 68 \\
\hline $29 A$ & 0,358 & 3628 & 7257 & 1,7 & 66 \\
\hline 29B & 0,379 & 3841 & 7682 & 1,7 & 68 \\
\hline $30 \mathrm{~A}$ & 0,396 & 4013 & 8027 & 1,8 & 71 \\
\hline $30 \mathrm{~B}$ & 0,423 & 4287 & 8574 & 1,8 & 71 \\
\hline $31 \mathrm{~A}$ & 0,406 & 4115 & 8230 & 1,6 & 65 \\
\hline $31 \mathrm{~B}$ & 0,504 & 5108 & 10216 & 1,9 & 75 \\
\hline $32 \mathrm{~A}$ & 0,047 & 476 & 953 & 0,2 & 7 \\
\hline 32B & 0,033 & 334 & 669 & 0,2 & 6 \\
\hline $33 \mathrm{~A}$ & 0,475 & 4814 & 9628 & 1,8 & 71 \\
\hline 33B & 0,503 & 5098 & 10196 & 1,8 & 72 \\
\hline
\end{tabular}


Table B.5 Analyses of aluminium in the filtrates produced.

\begin{tabular}{|c|c|c|c|}
\hline Number & Absorbance & $\begin{array}{c}\text { Concentration } \\
(\mathrm{mg} / \mathrm{l})\end{array}$ & $\begin{array}{l}\text { Percentage } \\
\text { extraction }\end{array}$ \\
\hline $17 \mathrm{~A}$ & 0,188 & 233 & 2 \\
\hline 17B & 0,196 & 244 & 3 \\
\hline $18 \mathrm{~A}$ & 0,261 & 340 & 6 \\
\hline $18 \mathrm{~B}$ & 0,244 & 316 & 5 \\
\hline $19 \mathrm{~A}$ & 0,284 & 359 & 9 \\
\hline 19B & 0,287 & 363 & 10 \\
\hline $20 \mathrm{~A}$ & 0,267 & 348 & 8 \\
\hline $20 \mathrm{~B}$ & 0,270 & 352 & 8 \\
\hline $21 \mathrm{~A}$ & 0,020 & 14 & 0 \\
\hline 21B & 0,034 & 32 & 1 \\
\hline $22 \mathrm{~A}$ & 0,256 & 333 & 7 \\
\hline 22B & 0,256 & 333 & 8 \\
\hline $23 \mathrm{~A}$ & 0,258 & 335 & 8 \\
\hline $23 \mathrm{~B}$ & 0,256 & 333 & 7 \\
\hline $24 \mathrm{~A}$ & 0,266 & 346 & 8 \\
\hline $24 \mathrm{~B}$ & 0,282 & 368 & 8 \\
\hline $25 \mathrm{~A}$ & 0,250 & 325 & 7 \\
\hline $25 B$ & 0,280 & 365 & 8 \\
\hline $26 \mathrm{~A}$ & 0,291 & 368 & 8 \\
\hline $26 \mathrm{~B}$ & 0,296 & 374 & 8 \\
\hline $27 \mathrm{~A}$ & 0,303 & 383 & 8 \\
\hline 27B & 0,292 & 369 & 8 \\
\hline $28 \mathrm{~A}$ & 0,330 & 419 & 9 \\
\hline $28 \mathrm{~B}$ & 0,308 & 390 & 8 \\
\hline $29 \mathrm{~A}$ & 0,254 & 330 & 8 \\
\hline $29 B$ & 0,254 & 330 & 7 \\
\hline $30 \mathrm{~A}$ & 0,278 & 351 & 8 \\
\hline $30 \mathrm{~B}$ & 0,265 & 334 & 7 \\
\hline $31 \mathrm{~A}$ & 0,274 & 346 & 7 \\
\hline $31 \mathrm{~B}$ & 0,274 & 346 & 6 \\
\hline $32 \mathrm{~A}$ & 0,052 & 55 & 1 \\
\hline $32 \mathrm{~B}$ & 0,053 & 56 & 1 \\
\hline $33 \mathrm{~A}$ & 0,120 & 147 & 3 \\
\hline $33 \mathrm{~B}$ & 0,118 & 145 & 3 \\
\hline
\end{tabular}


Table B.6 Analyses of gallium for the filtrates produced.

\begin{tabular}{|c|c|c|c|c|}
\hline Number & Absorbance & $\begin{array}{c}\text { Concentration } \\
(\mathrm{mg} / \mathrm{l})\end{array}$ & Mass in filtrate (g) & Percentage extraction \\
\hline $17 \mathrm{~A}$ & 0,040 & 25 & 0,003 & 6 \\
\hline 17B & 0,047 & 30 & 0,003 & 8 \\
\hline $18 \mathrm{~A}$ & 0,058 & 41 & 0,007 & 17 \\
\hline 18B & 0,052 & 36 & 0,006 & 14 \\
\hline $19 \mathrm{~A}$ & 0,138 & 43 & 0,010 & 25 \\
\hline 19B & 0,131 & 41 & 0,011 & 26 \\
\hline $20 \mathrm{~A}$ & 0,145 & 46 & 0,010 & 24 \\
\hline $20 \mathrm{~B}$ & 0,140 & 44 & 0,010 & 24 \\
\hline $21 \mathrm{~A}$ & 0,017 & 4 & 0,001 & 2 \\
\hline $21 \mathrm{~B}$ & 0,014 & 3 & 0,001 & 2 \\
\hline $22 \mathrm{~A}$ & 0,154 & 48 & 0,010 & 25 \\
\hline $22 B$ & 0,143 & 45 & 0,010 & 26 \\
\hline $23 \mathrm{~A}$ & 0,143 & 47 & 0,010 & 26 \\
\hline 23B & 0,144 & 47 & 0,010 & 24 \\
\hline $24 \mathrm{~A}$ & 0,146 & 48 & 0,011 & 26 \\
\hline 24B & 0,143 & 47 & 0,011 & 26 \\
\hline $25 \mathrm{~A}$ & 0,065 & 41 & 0,009 & 22 \\
\hline $25 B$ & 0,064 & 41 & 0,009 & 23 \\
\hline $26 \mathrm{~A}$ & 0,003 & 1 & 0,000 & 1 \\
\hline 26B & 0,002 & 1 & 0,000 & 0 \\
\hline $27 \mathrm{~A}$ & 0,050 & 34 & 0,007 & 18 \\
\hline 27B & 0,056 & 38 & 0,009 & 21 \\
\hline $28 \mathrm{~A}$ & 0,138 & 45 & 0,009 & 23 \\
\hline 28B & 0,146 & 48 & 0,010 & 25 \\
\hline $29 \mathrm{~A}$ & 0,062 & 42 & 0,010 & 24 \\
\hline $29 B$ & 0,145 & 47 & 0,010 & 26 \\
\hline $30 \mathrm{~A}$ & 0,063 & 43 & 0,010 & 23 \\
\hline $30 \mathrm{~B}$ & 0,145 & 47 & 0,010 & 24 \\
\hline $31 \mathrm{~A}$ & 0,067 & 43 & 0,008 & 21 \\
\hline $31 \mathrm{~B}$ & 0,066 & 42 & 0,008 & 19 \\
\hline $32 \mathrm{~A}$ & 0,003 & 0 & 0,000 & 0 \\
\hline $32 \mathrm{~B}$ & 0,003 & 0 & 0,000 & 0 \\
\hline $33 \mathrm{~A}$ & 0,020 & 6 & 0,001 & 2 \\
\hline 33B & 0,019 & 5 & 0,001 & 2 \\
\hline
\end{tabular}


Table B.7 Analyses of iron for the filtrates produced.

\begin{tabular}{|c|c|c|c|c|c|}
\hline Number & Absorbance & $\begin{array}{l}\text { Concentration } \\
(\mathrm{mg} / \mathrm{l}) \times 0.05\end{array}$ & $\begin{array}{c}\text { Concentration } \\
(\mathrm{mg} / \mathrm{l})\end{array}$ & $\begin{array}{c}\text { Mass } \\
\text { in filtrate }(\mathrm{g})\end{array}$ & $\begin{array}{l}\text { Percentage } \\
\text { Extraction }\end{array}$ \\
\hline $17 \mathrm{~A}$ & 0,458 & 90 & 1803 & 0,2 & 23 \\
\hline 17B & 0,437 & 86 & 1716 & 0,2 & 24 \\
\hline $18 \mathrm{~A}$ & 0,326 & 63 & 1257 & 0,2 & 28 \\
\hline $18 \mathrm{~B}$ & 0,352 & 68 & 1364 & 0,2 & 27 \\
\hline $19 \mathrm{~A}$ & 0,259 & 49 & 979 & 0,2 & 30 \\
\hline $19 B$ & 0,236 & 44 & 884 & 0,2 & 30 \\
\hline $20 \mathrm{~A}$ & 0,29 & 55 & 1108 & 0,2 & 31 \\
\hline $20 \mathrm{~B}$ & 0,279 & 53 & 1062 & 0,2 & 31 \\
\hline $21 \mathrm{~A}$ & 0,022 & 0 & $\mathbf{0}$ & 0,0 & 0 \\
\hline $21 \mathrm{~B}$ & 0,013 & 0 & $\mathbf{0}$ & 0,0 & 0 \\
\hline $22 \mathrm{~A}$ & 0,269 & 51 & 1021 & 0,2 & 28 \\
\hline $22 B$ & 0,268 & 51 & 1016 & 0,2 & 30 \\
\hline $23 \mathrm{~A}$ & 0,292 & 56 & 1116 & 0,3 & 32 \\
\hline $23 \mathrm{~B}$ & 0,436 & 86 & 1712 & 0,4 & 47 \\
\hline $24 \mathrm{~A}$ & 0,23 & 43 & 859 & 0,2 & 25 \\
\hline $24 B$ & 0,241 & 45 & 905 & 0,2 & 26 \\
\hline $25 \mathrm{~A}$ & 0,269 & 51 & 1021 & 0,2 & 28 \\
\hline 25B & 0,262 & 50 & 992 & 0,2 & 29 \\
\hline $26 \mathrm{~A}$ & 0,289 & 55 & 1103 & 0,2 & 30 \\
\hline $26 \mathrm{~B}$ & 0,297 & 57 & 1137 & 0,2 & 31 \\
\hline $27 \mathrm{~A}$ & 0,257 & 49 & 971 & 0,2 & 27 \\
\hline 27B & 0,299 & 57 & 1145 & 0,3 & 33 \\
\hline $28 \mathrm{~A}$ & 0,299 & 57 & 1145 & 0,2 & 30 \\
\hline $28 \mathrm{~B}$ & 0,279 & 53 & 1062 & 0,2 & 30 \\
\hline $29 \mathrm{~A}$ & 0,229 & 43 & 855 & 0,2 & 25 \\
\hline 29B & 0,316 & 61 & 1215 & 0,3 & 34 \\
\hline $30 \mathrm{~A}$ & 0,286 & 55 & 1091 & 0,2 & 31 \\
\hline $30 \mathrm{~B}$ & 0,299 & 57 & 1145 & 0,2 & 30 \\
\hline $31 \mathrm{~A}$ & 0,312 & 60 & 1199 & 0,2 & 30 \\
\hline $31 \mathrm{~B}$ & 0,347 & 67 & 1344 & 0,2 & 32 \\
\hline $32 \mathrm{~A}$ & 0,012 & 0 & 0 & 0,0 & 0 \\
\hline 32B & 0,011 & 0 & 0 & 0,0 & 0 \\
\hline $33 \mathrm{~A}$ & 0,022 & 0 & 0 & 0,0 & 0 \\
\hline $33 \mathrm{~B}$ & 0,017 & 0 & 0 & 0,0 & 0 \\
\hline
\end{tabular}


Table B.8 Analyses of magnesium for the filtrates produced.

\begin{tabular}{|c|c|c|c|c|c|}
\hline Number & Absorbance & $\begin{array}{c}\text { Concentration } \\
(\mathrm{mg} / \mathrm{l}) \times 0,001\end{array}$ & $\begin{array}{l}\text { Concentration in } \\
\text { filtrate }(\mathrm{mg} / \mathrm{l})\end{array}$ & $\begin{array}{c}\text { Mass in filtrate } \\
(\mathrm{g})\end{array}$ & $\begin{array}{l}\text { Percentage } \\
\text { extraction }\end{array}$ \\
\hline $17 \mathrm{~A}$ & 0,803 & 21,3 & 42673 & \begin{tabular}{|l|}
4,3 \\
4
\end{tabular} & 92 \\
\hline 17B & 0,707 & 18,7 & 37445 & 4,1 & 89 \\
\hline $18 \mathrm{~A}$ & 0,652 & 17,2 & 34450 & 5,9 & 127 \\
\hline $18 \mathrm{~B}$ & 0,72 & 19,1 & 38153 & 6,0 & 128 \\
\hline $19 \mathrm{~A}$ & 0,594 & 15,6 & 31292 & 7,5 & 162 \\
\hline 19B & 0,595 & 15,7 & 31346 & 8,3 & 178 \\
\hline $20 \mathrm{~A}$ & 0,609 & 16,1 & 21528 & 4,7 & 100 \\
\hline $20 \mathrm{~B}$ & 0,587 & 15,5 & 30910 & 7,0 & 152 \\
\hline $21 \mathrm{~A}$ & 0,439 & 11,4 & 22851 & 4,9 & 105 \\
\hline $21 \mathrm{~B}$ & 0,368 & 9,5 & 18985 & 5,9 & 128 \\
\hline $22 \mathrm{~A}$ & 0,578 & 15,2 & 30420 & 6,5 & 139 \\
\hline 22B & 0,534 & 14,0 & 28024 & 6,5 & 140 \\
\hline $23 \mathrm{~A}$ & 0,576 & 15,2 & 30312 & 6,8 & 147 \\
\hline $23 \mathrm{~B}$ & 0,597 & 15,7 & 31455 & 6,7 & 143 \\
\hline $24 \mathrm{~A}$ & 0,547 & 14,4 & 20852 & 4,7 & 100 \\
\hline $24 B$ & 0,545 & 14,3 & 28623 & 6,5 & 140 \\
\hline $25 \mathrm{~A}$ & 0,572 & 15,0 & 30094 & 6,5 & 139 \\
\hline $25 \mathrm{~B}$ & 0,556 & 14,6 & 29222 & 6,7 & 145 \\
\hline $26 \mathrm{~A}$ & 0,599 & 15,8 & 31564 & 6,6 & 143 \\
\hline $26 \mathrm{~B}$ & 0,617 & 16,3 & 32544 & 7,0 & 150 \\
\hline $27 \mathrm{~A}$ & 0,538 & 14,1 & 28242 & 6,2 & 132 \\
\hline $27 B$ & 0,485 & 12,7 & 25356 & 5,7 & 122 \\
\hline $28 \mathrm{~A}$ & 0,593 & 15,6 & 31237 & 6,4 & 138 \\
\hline $28 \mathrm{~B}$ & 0,596 & 15,7 & 31401 & 6,8 & 147 \\
\hline $29 \mathrm{~A}$ & 0,535 & 14,0 & 28079 & 6,4 & 138 \\
\hline $29 B$ & 0,558 & 14,7 & 29331 & 6,5 & 139 \\
\hline $30 \mathrm{~A}$ & 0,601 & 15,8 & 31673 & 7,0 & 151 \\
\hline $30 \mathrm{~B}$ & 0,641 & 16,9 & 33851 & 7,0 & 151 \\
\hline $31 \mathrm{~A}$ & 0,608 & 16,0 & 32054 & 6,3 & 136 \\
\hline $31 \mathrm{~B}$ & 0,661 & 17,5 & 34940 & 6,4 & 138 \\
\hline $32 \mathrm{~A}$ & 0,533 & 14,0 & 23724 & 4,7 & 100 \\
\hline $32 \mathrm{~B}$ & 0,46 & 12,0 & 23995 & 4,9 & 106 \\
\hline $33 \mathrm{~A}$ & 0,747 & 19,8 & 25272 & 4,7 & 100 \\
\hline 33B & 0,806 & 21,4 & 42836 & 7,5 & 162 \\
\hline
\end{tabular}




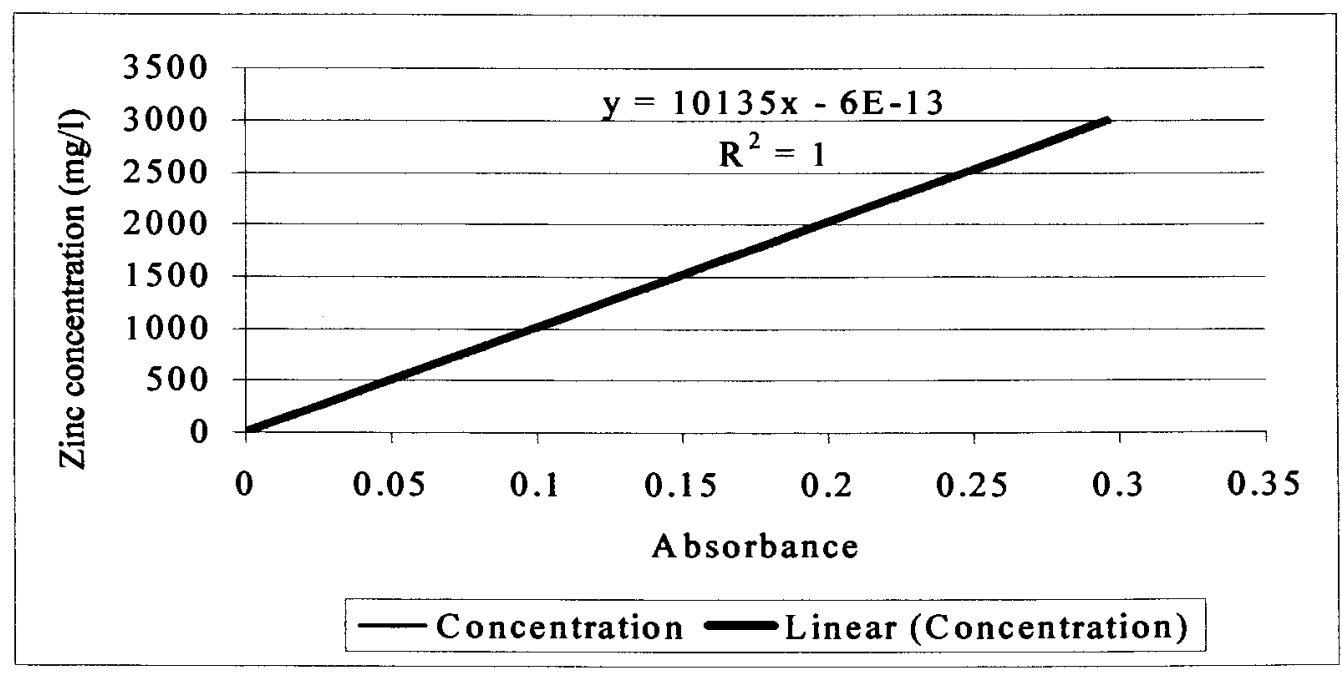

Figure B.1 Calibration curve for zinc concentration against absorbance.

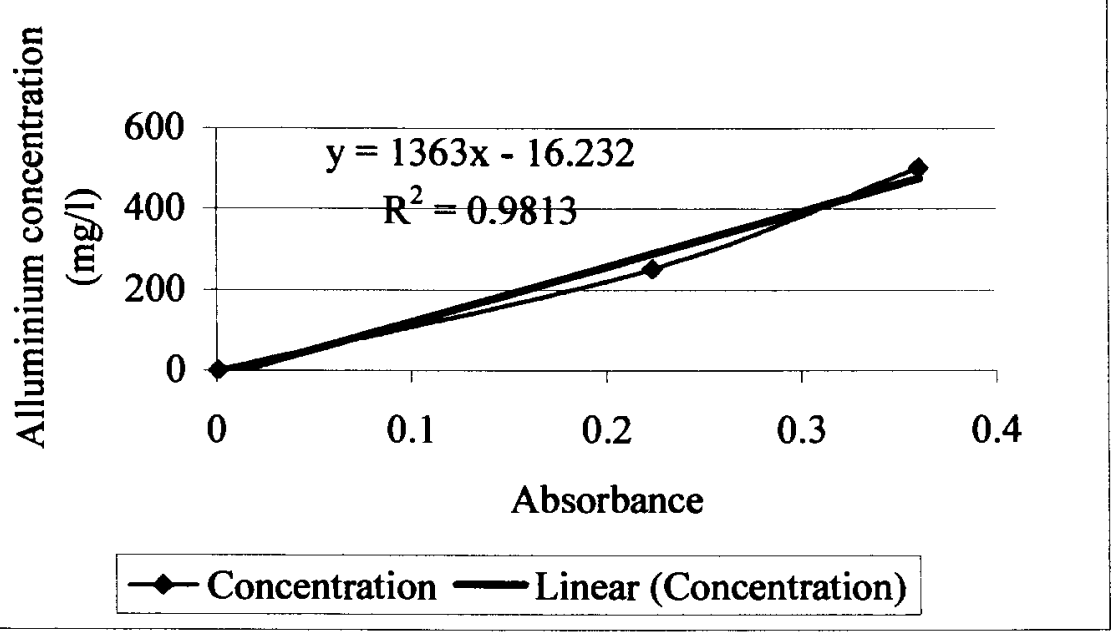

Figure B.2 Calibration curve for alluminium concentration against absorbance. 


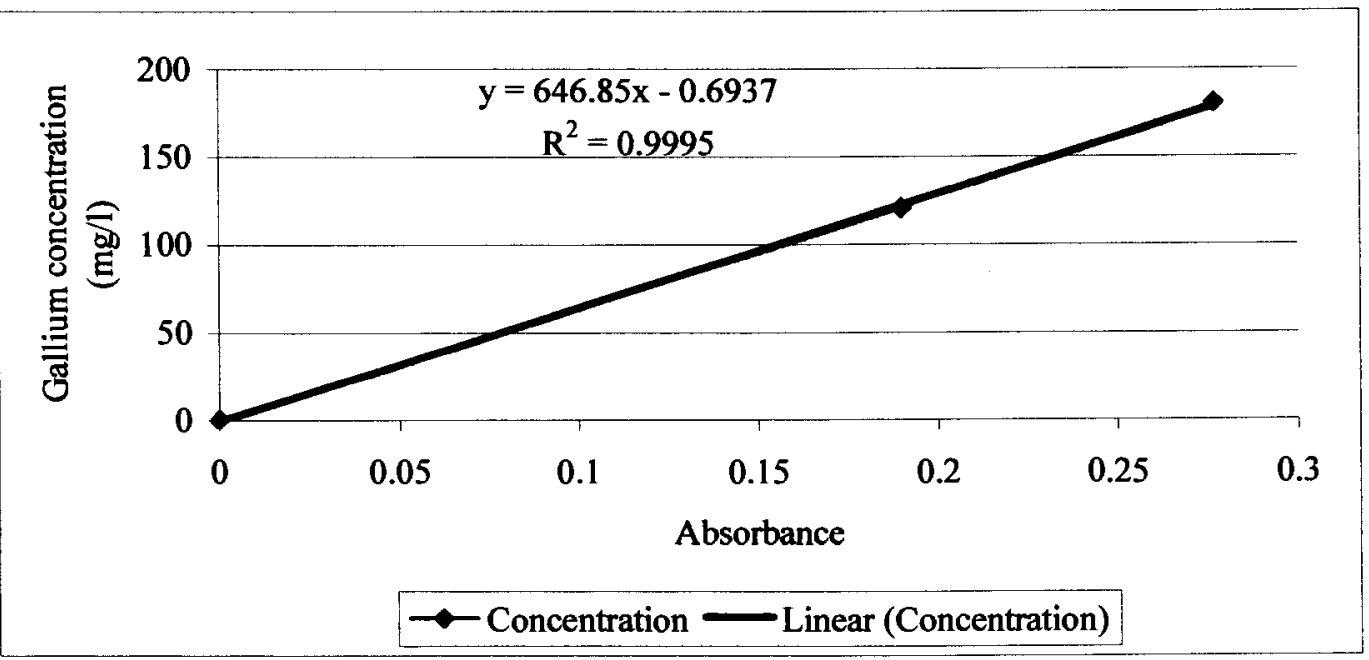

Figure B.3 Calibration curve for gallium concentration against absorbance.

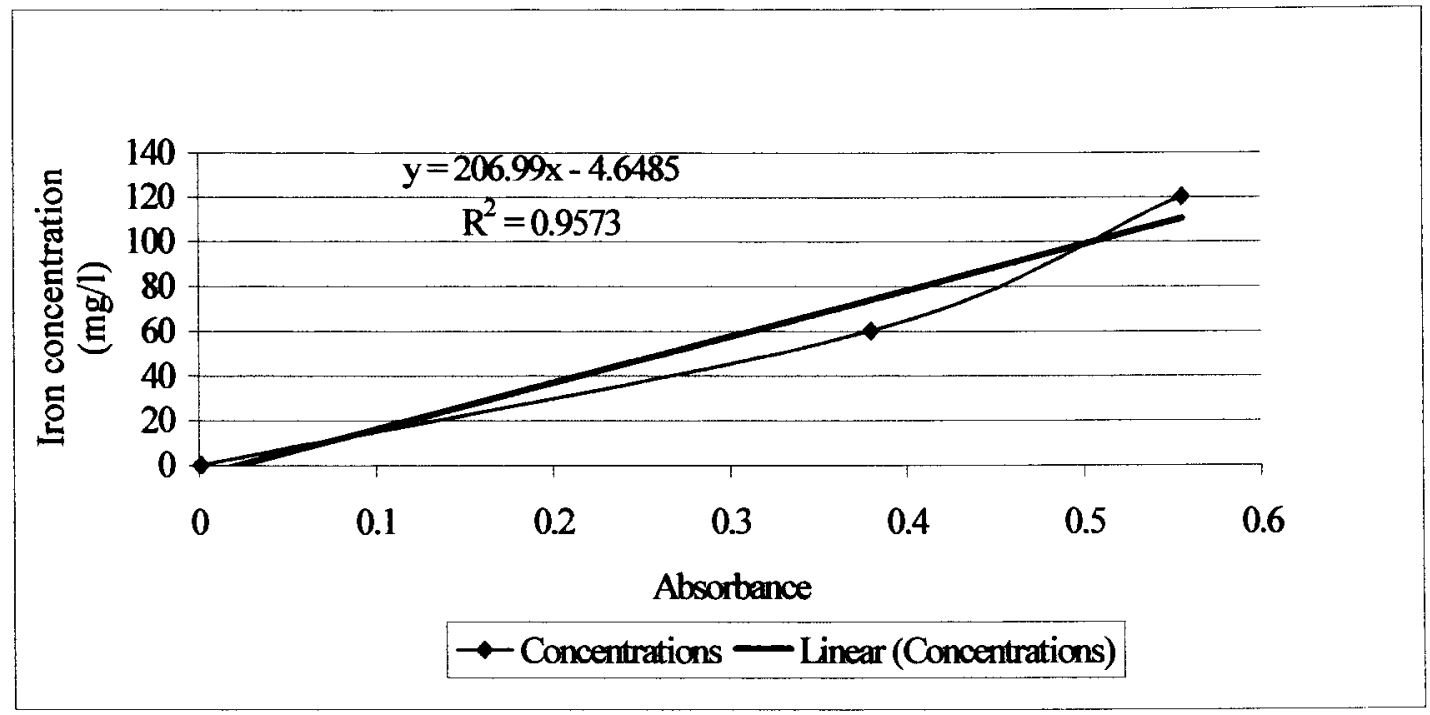

Figure B.4 Calibration curve for iron concentration against absorbance. 


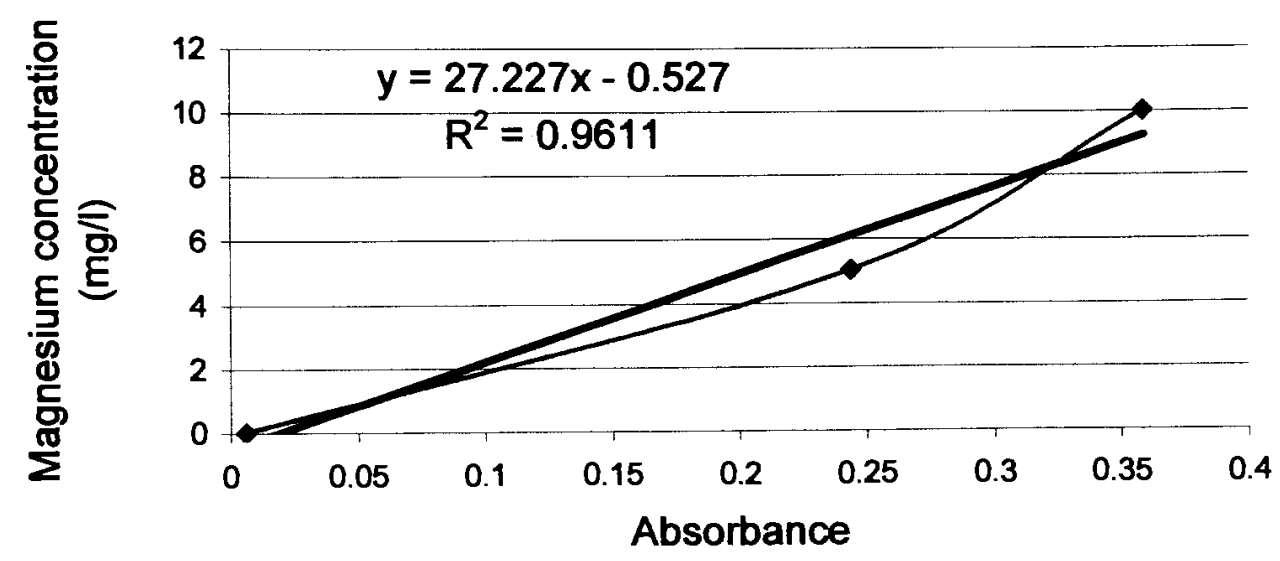

$\rightarrow$ Concentrations - Linear (Concentrations)

Figure B.5 Calibration curve for magnesium concentration against absorbance. 